\title{
Regionalization vs. Globalization
}

Hideaki Hirata, M. Ayhan Kose and Christopher Otrok 


\title{
IMF Working Paper
}

\author{
Research Department
}

\section{Regionalization vs. Globalization}

\section{Prepared by Hideaki Hirata, M. Ayhan Kose and Christopher Otrok ${ }^{1}$}

\author{
Authorized for distribution by Stijn Claessens
}

January 2013

\begin{abstract}
This Working Paper should not be reported as representing the views of the IMF. The views expressed in this Working Paper are those of the author(s) and do not necessarily represent those of the IMF or IMF policy. Working Papers describe research in progress by the author(s) and are published to elicit comments and to further debate.
\end{abstract}

\begin{abstract}
Both global and regional economic linkages have strengthened substantially over the past quarter century. We employ a dynamic factor model to analyze the implications of these linkages for the evolution of global and regional business cycles. Our model allows us to assess the roles played by the global, regional, and country-specific factors in explaining business cycles in a large sample of countries and regions over the period 1960-2010. We find that, since the mid-1980s, the importance of regional factors has increased markedly in explaining business cycles especially in regions that experienced a sharp growth in intra-regional trade and financial flows. By contrast, the relative importance of the global factor has declined over the same period. In short, the recent era of globalization has witnessed the emergence of regional business cycles.
\end{abstract}

JEL Classification Numbers:C11, C32, E32, F41, F42

Keywords: Business cycles; Comovement; Synchronization; Trade linkages; Financial linkages Author's E-Mail Address: h-hirata@hosei.ac.jp; akose@imf.org; otrokc@missouri.edu

\footnotetext{
${ }^{1}$ Hirata: Faculty of Business Administration, Hosei University and Japan Center for Economic Research; Kose: Research Department, International Monetary Fund; Otrok: Department of Economics, University of MissouriColumbia and Federal Reserve Bank of St Louis. Earlier versions of this paper were presented at the Federal Reserve Bank of St Louis Conference on "Challenges in Open-Economy Macroeconomics after the Financial Crisis," the CESIFO Venice Summer Institute on "Global Interdependence, Decoupling and Recoupling," the CEPR-RIETI Conference on "International Finance and Corporate Finance: Japanese and European Perspectives," the Spring Meetings of the Japan Economic Association, and seminars at the Bank of Japan, the Canon Institute for Global Studies, the Federal Reserve Bank of San Francisco, and UC-Berkeley. We would like to thank our discussants (Sebnem Kalemli-Ozcan, Claudia M. Buch, John Driffill, and Yosuke Takeda), Stijn Claessens, Massimiliano Marcellino, numerous colleagues, and seminar and conference participants for their useful comments. Ezgi O. Ozturk provided excellent research assistance. Hirata has received financial support for this project under the Japan Society for the Promotion of Science Grant-in-Aid for Young Scientists (B) 24730253. The views expressed in this paper are those of the authors and do not necessarily represent views and policies of the IMF or Federal Reserve Bank of St Louis.
} 


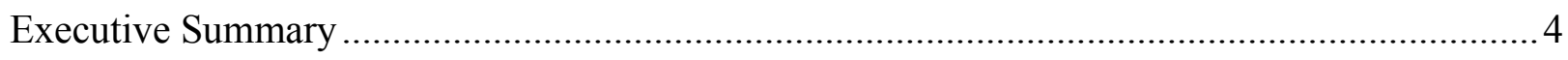

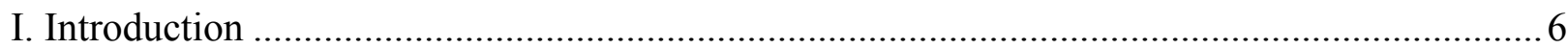

II. What Do We Know about the Evolution of Global and Regional Business Cycles? .............. 8

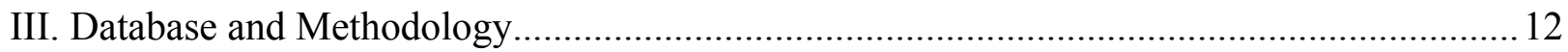

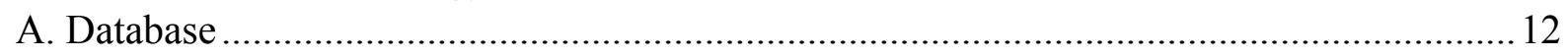

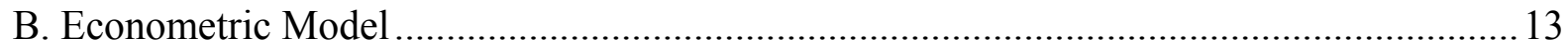

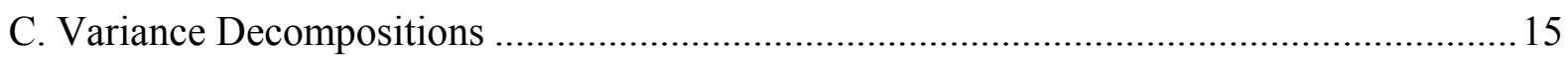

IV. How Important Are Regional Cycles (1960-2010)? ...................................................... 16

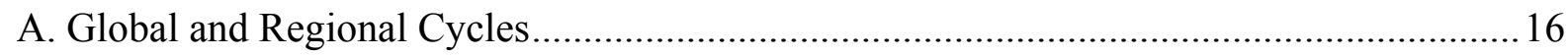

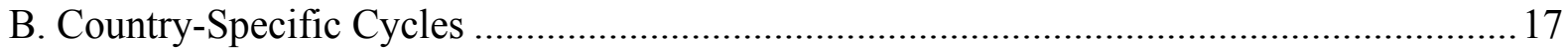

C. Global, Regional, and Country Factors .................................................................... 18

V. Business Cycles: Regionalization or Globalization? (1960-84 and 1985-2010)................. 19

A. Evolution of Global and Regional Cycles...................................................................20

B. Synchronization of Cycles in Consumption and Investment .......................................23

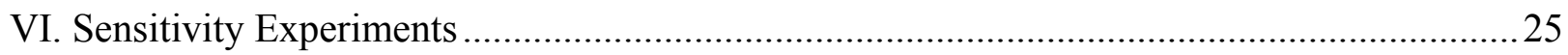

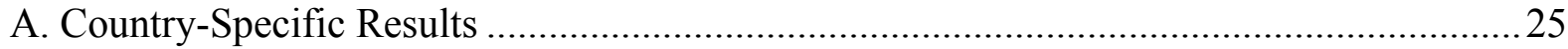

B. Demarcation of Time and Configuration of Regions ...............................................26

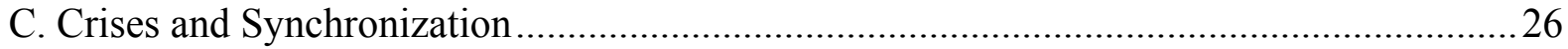

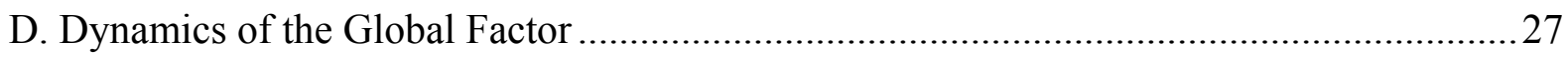

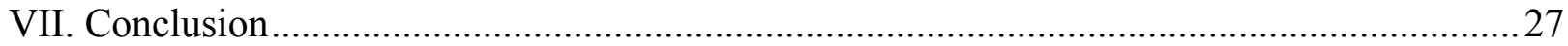

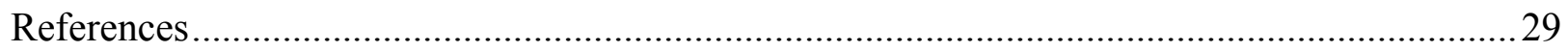

Tables

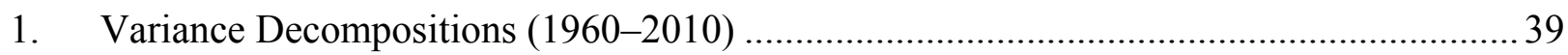

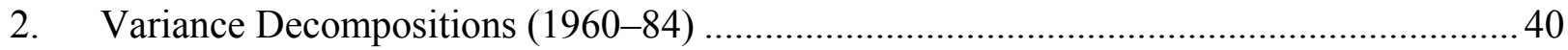

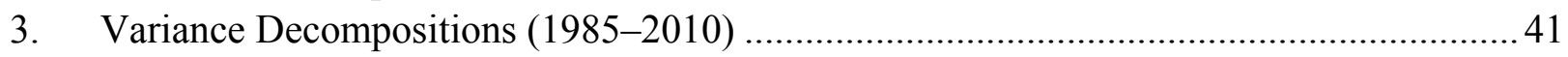

4. Variance Decompositions for the World (Different Breaks) .......................................... 42

5. Variance Decompositions for the World (Different End Years) ................................... 43 
Figures

1. Average Variance Explained by Global and Regional Factors (1960-2010).................. 44

2. Variance Explained by Global Factor..................................................................... 45

3. Variance Explained by Regional Factors..................................................................... 46

4. Variance Explained by Global and Regional Factors ................................................. 47

5. Output Variance Explained by Global Factor............................................................... 48

6. Output Variance Explained by Regional Factor ....................................................... 49

Appendix

I. List of Regions and Countries...........................................................................50

II. Summary of Empirical Studies on Synchronization of Cycles in Different Regions.........51 


\section{EXECUTIVE SUMMARY}

The inexorable forces of globalization and regionalization have reshaped the world economic landscape over the past quarter century. Global trade and financial flows have registered unprecedented growth during this period. Intra-regional economic linkages have also become much stronger with the proliferation of regional trade agreements and common currency areas.

These developments have appeared to affect the evolution of global and regional business cycles in unexpected ways. For example, despite the presence of strong global trade and financial linkages, there was significant variation in growth performance across different regions during the 2008-09 global financial crisis. Specifically, some regions (e.g., Asia) exhibited surprising resilience during the worst of the financial crisis and rapidly returned to high growth whereas some others (e.g., North America and Europe) experienced deep and prolonged contractions.

These observations lead to a basic question: "Have regional elements become more important in driving business cycles in an era of globalization?" We answer this question using a dynamic factor model. Our model allows us to analyze the sources of fluctuations in output, consumption, and investment in a sample of 106 countries over the period 1960-2010. We consider cycles in seven regions: North America, Europe, Oceania, Asia, Latin America and the Caribbean, Middle East and North Africa, and Sub-Saharan Africa.

Our results point to a surprising conclusion: The recent era of globalization has witnessed the emergence of regional business cycles. In particular, we find that:

- Since the mid-1980s, the importance of regional factors has increased markedly in explaining business cycles especially in regions that experienced a sharp growth in intra-regional trade and financial flows (Figure A). These patterns are particularly strong among the North American, European, Oceanian, and Asian regions (Figure B).

- By contrast, the importance of the global factor has declined over the same period (Figure C). Moreover, there has been no significant change in the degree of international synchronization of cycles as measured by the joint contribution of the global and region-specific factors to fluctuations during the past quarter century (Figure D). These patterns are valid not only for output, but also for consumption and investment fluctuations.

These results present a different interpretation of the impact of globalization on the synchronization of business cycles. Most commentators argue that globalization of trade and financial linkages have led to the globalization of business cycles as well. Contrary to these popular arguments, regional factors, rather than global ones, have become the driving forces of business cycles during the recent era of globalization. These factors have led to the emergence of regional business cycles.

A wide range of developments at the regional level can explain the emergence of regional cycles. For example, the dramatic increase in intra-regional trade and financial flows fueled by regional integration initiatives can promote a higher degree of business cycle synchronization across countries in a region. Regional business cycles can also emerge because of the prominent role of regionspecific shocks driven by the implementation of similar policies in a region. Moreover, cross-border spillovers of disturbances originating in a large country in a region can translate into more synchronized national business cycles in that region. We discuss these interpretations and provide a comprehensive review of the large literature on the synchronization of global and regional cycles. 
Figure A. Emergence of Regional Cycles

Regional cycles becoming more pronounced...

(Variance explained by regional factors)

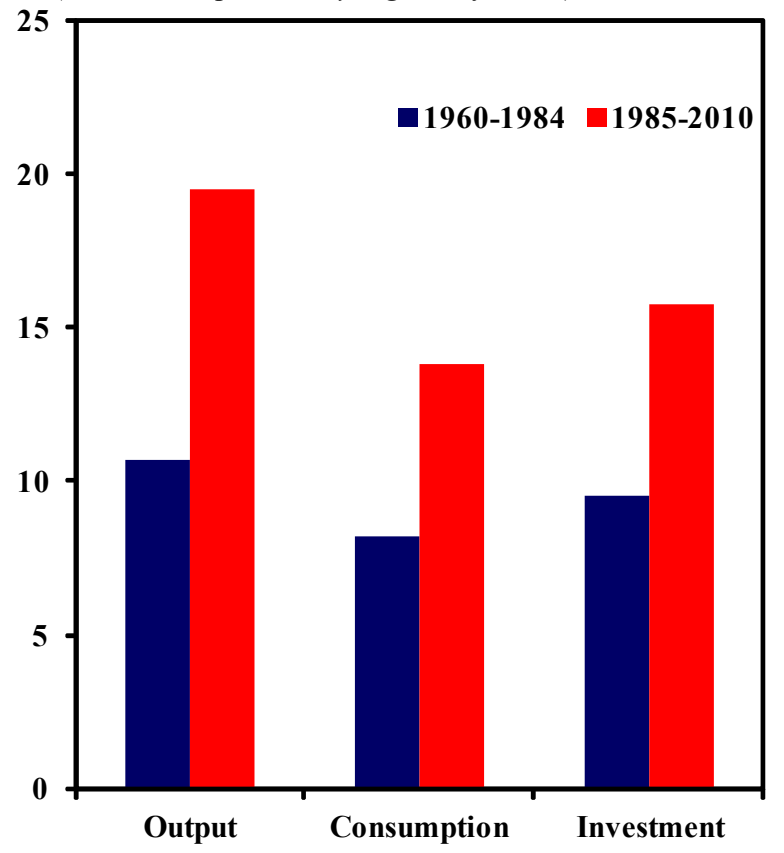

Global factor becoming less important...

(Variance explained by the global factor)

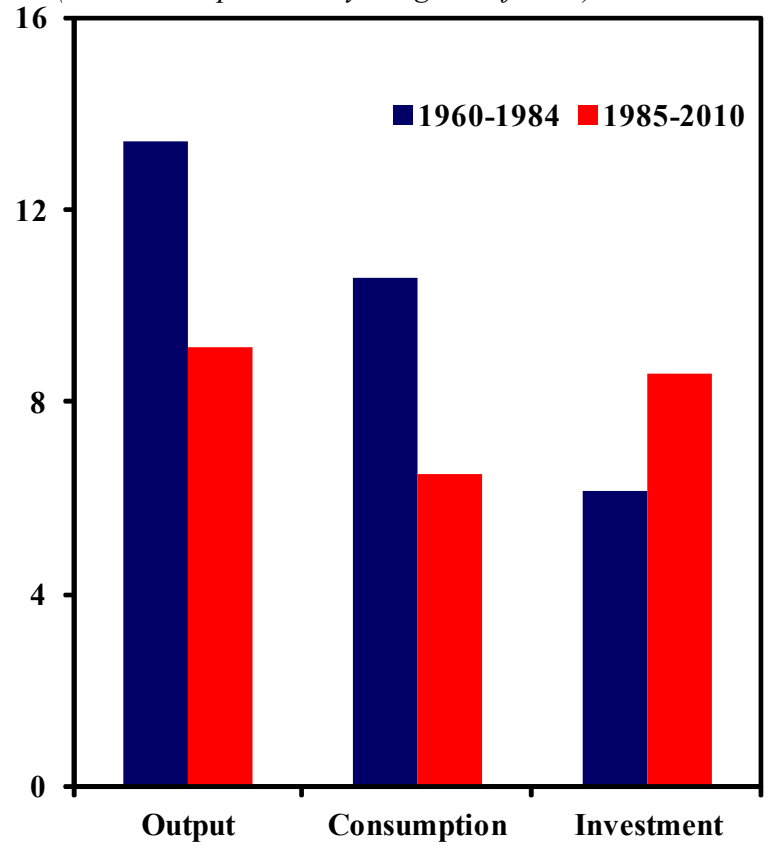

Especially in those with stronger intra-regional linkages. (Output variance explained by regional factors)

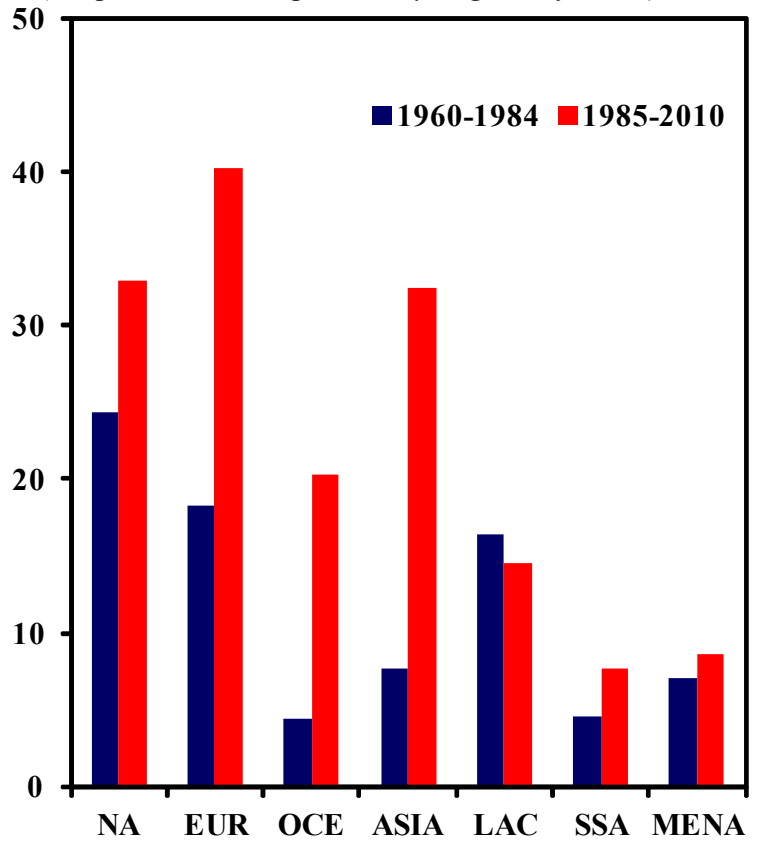

But, not much change in overall synchronization. (Variance explained by the global and regional factors)

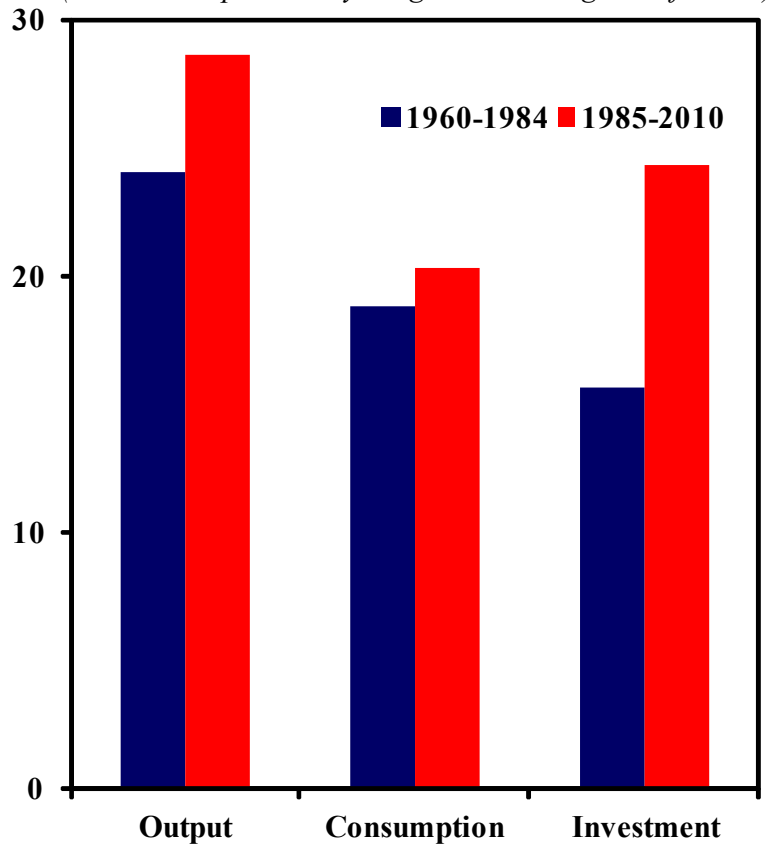

Notes: We estimate the model separately over the two periods, 1960-84 (yellow) and 1985-2010 (blue). We then compute the variance decompositions for each country, for output, consumption and investment in each of these two periods. Each bar then represents the cross-sectional mean of the variance share (in percent) attributable to the respective factors for that particular variable in a given period. 


\section{INTRODUCTION}

The inexorable forces of globalization and regionalization have reshaped the world economic landscape over the past quarter century. Global trade and financial flows have registered unprecedented growth during this period. Intra-regional economic linkages have also become much stronger with the proliferation of regional trade agreements and common currency areas.

These developments have appeared to affect the evolution of global and regional business cycles in unexpected ways. For example, despite the presence of strong global trade and financial linkages, there was significant variation in growth performance across different regions during the 2008-09 financial crisis. Specifically, some regions (e.g., Asia) exhibited surprising resilience during the worst of the financial crisis and rapidly returned to high growth whereas some others (e.g., North America and Europe) experienced deep and prolonged contractions. ${ }^{2}$

These observations lead to a basic question: "Have regional elements become more important in driving business cycles in an era of globalization?" We answer this question using a dynamic factor model. Our model allows us to analyze the sources of fluctuations in output, consumption, and investment in a large sample of countries over a long period of time. Specifically, it includes 106 countries over the period 1960-2010 and covers seven geographical regions: North America, Europe, Oceania, Asia, Latin America and the Caribbean, Middle East and North Africa, and Sub-Saharan Africa. The model decomposes fluctuations in these variables into four factors: a global factor that captures the broad common elements in the fluctuations across countries; regional factors, which capture the common elements in the cyclical fluctuations in the countries in a particular region; country-specific factors, which capture factors common to all variables in a particular country; and residual ("idiosyncratic") factors, which are associated with elements in the fluctuations of an individual variable that cannot be attributed to the other factors.

Our results indicate that, since the mid-1980s, the importance of regional factors has increased markedly in explaining business cycles especially in regions that experienced a sharp growth in intra-regional trade and financial flows. These patterns are particularly strong among the North American, European, Oceanian, and Asian regions. By contrast, the importance of the global factor has declined over the same period. Moreover, there has been no significant change in the degree of international synchronization of cycles as measured by the joint contribution of the global and region-specific factors to fluctuations during the past quarter century. These patterns are valid not only for output, but also for consumption and investment fluctuations. In short, the recent era of globalization has witnessed the emergence of regional business cycles.

There have been profound changes in the volume, direction, and nature of international trade and financial flows over the past quarter century (Kose and Prasad, 2010). These changes certainly have global dimensions, but at the same time they have also been driven by regional forces. First, while global trade flows have been growing at a much faster rate than world output, intra-

\footnotetext{
${ }^{2}$ A number of studies analyze the sources of variation in performance across different countries and regions during the global financial crisis (Blanchard, Faruqee, and Das, 2010; Lane and Milesi-Ferretti, 2011; Rose and Spiegel, 2011).
} 
regional trade flows have been playing an increasingly more prominent role in global trade. This reflects, in part, the process of economic unification in different regions and some emerging economies' (e.g., China, India, and Korea) rapid growth during the past quarter century. In addition, intra-regional trade and financial linkages have further strengthened by the explosion in the number of regional trade agreements (from 5 in 1985 to 200 in 2011). ${ }^{3}$

Second, intra-industry trade flows have contributed significantly to the unprecedented increase in global trade during the past two decades. These flows have grown rapidly in certain regions, including North America, Europe and Asia. ${ }^{4}$ International vertical specialization, which refers to the fragmentation of production processes into sequential chains in multiple countries, has been a major factor fuelling the substantial increase in global trade flows. This has led to a significant rise in the ratio of trade to value added in North America, Europe, Asia, and some parts of Latin America (Hummels, Ishii, and Yi, 2001; and Yi, 2003).

Moreover, the volume of global financial flows has reached unprecedented levels since the mid1980s overshadowing the increase in global trade over the same period. Intra-regional flows have also been on the rise for the past 15 years, especially in Europe and Asia. Financial flows among advanced economies have still been the main driving force of the increase in international financial flows, but there has also been a significant rise in flows between regions with advanced countries and those with developing economies over the past 25 years (Lane and Milesi-Ferretti, 2007; Milesi-Ferretti, Strobbe, and Tamirisa, 2010).

Neither economic theory nor empirical research provides definitive guidance concerning the impact of increased trade and financial linkages on the degree of synchronization of global and regional cycles. On the one hand, international trade and financial linkages generate both demand and supply-side spillovers across countries that can result in more highly correlated business cycles. On the other hand, if stronger trade and financial linkages are associated with increased specialization, they can lead to a decline in the degree of business cycle synchronization. While a number of empirical studies conclude that trade linkages have a positive effect, they report mixed findings on the impact of financial flows on the synchronization of business cycles. Although the quantitative importance of region-specific factors in explaining business cycles has been an area of intensive study, the results of this research program have been far from conclusive.

In light of the mutually complementary nature of globalization and regionalization, we turn to an empirical approach that has the potential to provide a comprehensive perspective on the evolution of global and regional business cycles. Our methodology builds on our earlier work (Kose, Otrok, and Whiteman, 2003), but we consider a different question and employ a much larger dataset with a substantially longer time span in this paper (see Appendix I for the sample of countries and regions). The use of a large sample of countries allows us to draw a sharp

\footnotetext{
${ }^{3}$ These numbers are based on the statistics from the WTO's Regional Trade Agreements Gateway. For a detailed discussion of the evolution of preferential and regional trade agreements, see WTO (2011).

${ }^{4}$ Ando (2006), Athukorala and Yamashita (2006), Clark (2002), Fullerton, Sawyer, Sprinkle (2011) present evidence for the rapid growth of intra-industry trade in Asia, North America, and the Latin America and the Caribbean.
} 
contrast across different regions in terms of their exposure to external shocks. In addition, the relatively long time span of the data enables us to consider distinct sub-periods and to analyze the changes in business cycles that have taken place during the recent wave of globalization (1985-2010) relative to the earlier period. These differences are essential to uncover our headline result on the emergence of regional cycles.

Our model simultaneously captures contemporaneous spillovers of shocks as well as the dynamic propagation of business cycles in a flexible manner, without a priori restrictions on the directions of spillovers or the structure of the propagation mechanism. The dynamic factor model we employ can be seen as a reduced-form solution of a standard open economy Dynamic Stochastic General Equilibrium (DSGE) model in the sense that data generated from that model has an approximate representation as a dynamic factor model (Crucini, Kose, and Otrok, 2011). However, typical DSGE models face the curse of dimensionality that limits the number of shocks and driving variables that can be analyzed in these models. Our factor model provides a parsimonious representation of the data, allowing us to consider a large number of macroeconomic variables to study the evolution of global and regional business cycles.

The estimated global, regional and country factors in our model reflect elements of commonality of fluctuations in different dimensions of the data. The importance of studying all of these factors in one model is that they obviate problems that could be caused by studying a subset of factors, which could lead to a mischaracterization of commonality. For instance, regional factors estimated in a smaller model may simply reflect global factors that are misidentified as being specific to a particular region. Moreover, by including different macroeconomic aggregates, we get better measures of the commonality of fluctuations in overall economic activity. ${ }^{5}$

We present a brief survey of theoretical and empirical studies on the impact of integration on the degree of business cycle synchronization in Section II. Our empirical model and database are introduced in Section III. Section IV reports the results of estimations for the full sample. Section $\mathrm{V}$ discusses the evolution of global and regional cycles over time. Section VI summarizes the results of our sensitivity experiments. Section VII concludes.

\section{What Do We KnOW about the Evolution of Global AND Regional BuSiness CYCles?}

What are the implications of increasing trade and financial integration for the evolution of global and regional business cycles? This section provides a brief review of theoretical and empirical studies focusing on this question. We start with a summary of the basic predictions of theory with respect to the implications of integration on business cycle synchronization. Next, we discuss the results of empirical studies analyzing the linkages between integration and

\footnotetext{
${ }^{5}$ We analyze global and regional business cycles based on a few key macroeconomic variables rather than focusing solely on output. Our approach of using multiple macroeconomic indicators rather than just GDP to characterize business cycles can be traced back to classical scholars of business cycles (Burns and Mitchell, 1946; Zarnowitz, 1992). The NBER also looks at a variety of indicators for determining turning points in U.S. business cycles, including real GDP, real income, employment, industrial production, and wholesale-retail sales.
} 
synchronization. We conclude with a short summary of the research program on the importance of global and regional factors in explaining business cycles.

Our brief review highlights the three major findings of this literature. First, theoretical studies are inconclusive about the effects of integration on the degree of synchronization of business cycles. Second, most empirical studies suggest that trade integration has a positive impact on synchronization, but the role of financial integration in driving business cycles is still an open question. Third, while there is an extensive literature about regional dimensions of business cycles, these studies fail to provide a clear conclusion with respect to the evolution of these cycles. Differences in country coverage, sample periods, aggregation methods used to create country groups, and econometric methods employed appear to lead to diverse conclusions about the temporal evolution of synchronization. Our review also shows that there has been no comprehensive study analyzing the evolution of global and regional cycles using a large sample of countries and regions over a long time period.

Theoretical Implications. There is no consistent theoretical prediction across different models about how trade and financial integration should affect the degree of synchronization of business cycles. For example, international trade linkages generate both demand and supply-side spillovers across countries. Through these types of spillover effects, stronger trade linkages can result in more highly correlated business cycles. Increased intra-industry trade and vertical specialization could further amplify these spillover effects.

However, both classical and "new" trade theories imply that increased trade linkages also lead to increased specialization. The impact of increased specialization on the degree of comovement depends on the nature of specialization (intra- vs. inter-industry) and the types of shocks (common vs. country-specific). If stronger trade linkages are associated with increased interindustry specialization across countries, then the impact of increased trade depends on the nature of shocks. If industry-specific shocks are more important in driving business cycles, then business cycle comovement is expected to decrease (Krugman, 1993). If common shocks are more dominant than industry-specific ones, then this would lead to a higher degree of comovement (Frankel and Rose, 1998).

The impact of increased financial flows on the synchronization of business cycles is also ambiguous in theory. By generating large demand-side effects, financial linkages could result in a higher degree of synchronization of output fluctuations. Contagion effects that are transmitted through financial linkages could also result in heightened cross-country spillovers of macroeconomic fluctuations (Claessens and Forbes, 2001).

However, international financial linkages could also stimulate specialization of production through the reallocation of capital in a manner consistent with countries' comparative advantage in the production of different goods (Kalemli-Ozcan and others, 2001). Such specialization of production, which could result in more exposure to industry- or country-specific shocks, could lead to lower business cycle correlations. More generally, financial integration, by helping countries to diversify away country-specific risk associated with consumption fluctuations, should result in stronger comovement of consumption fluctuations across countries. The impact 
of financial integration also depends on the nature of financial flows: equity flows appear to reduce the degree of comovement while debt flows tend to increase it (Davis, 2011).

Empirical Implications. A number of empirical studies find that trade linkages have a positive impact on the synchronization of business cycles suggesting that the traditional demand and supply spillovers dominate the effects of specialization associated with inter-industry trade flows (Frankel and Rose, 1998; Kose, and Yi, 2006). Trade intensity also has a larger effect on crosscountry business cycle correlations in countries with stronger intra-industry trade linkages and more similar sectoral structures (Imbs, 2004; Calderon, Chong, and Stein, 2007). Moreover, some studies document that regional trade agreements, such as NAFTA, tend to have a positive impact on comovement (Calderon, 2003; Bejan, 2011).

Empirical studies report mixed findings on the impact of financial flows on the degree of business cycle comovement. For example, Imbs (2006) reports that financial integration leads to higher output and consumption correlations in advanced countries. This effect appears to be much smaller in the case of developing countries (Kose, Prasad, and Terrones, 2003). Jansen and Stokman (2004) find that countries with stronger FDI linkages have more correlated business cycles in the second half of the 1990s whereas Kalemli-Ozcan, Papaioannou, and Peydro (2011) report a strong negative effect of banking integration on the degree of output synchronization.

Research has been unable to provide a concrete explanation about the evolution of comovement properties of the main macroeconomic aggregates over time in response to changes in the volume of trade and financial flows. Some of these studies find evidence of declining output correlations among industrial economies over the last three decades. For example, Heathcote and Perri (2004) document that the correlations of output, consumption, and investment between the United States and an aggregate of Europe, Canada, and Japan are lower in the period 1986-2000 than in $1972-85 .^{6}$

However, other studies document that business cycle linkages have become stronger over time. Kose, Otrok, and Whiteman (2008), for example, employ a dynamic factor model to analyze the evolution of comovement across the G-7 countries. They document that the common factor on average explains a larger fraction of output, consumption, and investment volatility in the 19862003 period than that in 1960-72. They interpret this result as an indication of increasing degree of business cycle synchronization in the age of globalization. Using a longer sample of annual data, Artis and others (2011b) and Bordo and Helbling (2011) also document that the degree of synchronization across advanced countries has increased over time.

Regional Business Cycles. The quantitative importance of region-specific factors in explaining the degree of business cycle synchronization has been an area of intensive study. Although this research program has utilized a variety of methodologies (cross-section and panel regressions,

\footnotetext{
${ }^{6}$ In a related paper, Stock and Watson (2003) employ a factor-structural VAR model to analyze the importance of international factors in explaining business cycles in the G-7 countries since 1960. They conclude that comovement has fallen in the 1984-2002 period relative to 1960-83 due to diminished importance of common shocks. Results by Doyle and Faust (2005) indicate that there is no significant change in the correlations between the growth rate of output in the United States and in other G-7 countries over time.
} 
VAR, FAVAR and dynamics factor models), the results have been far from conclusive. We briefly survey a select set of studies focusing on different regions here. We present a summary of a number of empirical studies on the synchronization of business cycles in different regions in Appendix II.

Research on the existence of a common European business cycle has produced inconclusive results (De Haan, Inklaar, Jong-a-Pin, 2008; Giannone, Lenza, and Reichlin, 2010). Artis and Zhang (1997), Bergman and others (1998), Lumsdaine, and Prasad (2003) and Artis, Krolzig, and Toro (2004) analyze the implications of integration for the synchronization of business cycles in the advanced European countries and confirm the presence of a region specific cycle. However, Artis (2003), Canova, Ciccarelli, Ortega (2007), and Camacho, Perez-Quiros, and Saiz (2008) argue that the empirical evidence does not support a specific European cycle since the 1990s.

Some studies suggest that the rapid increase in intra-regional trade flows appears to be a major driving force of the high degree of synchronization of business cycles in various regions. For example, the North American Free Trade Agreement (NAFTA) has been associated with a substantial increase in the degree of business cycle synchronization between Canada, Mexico, and the United States (Bergman and others, 1998; Kose, Meredith, and Towe, 2005). ${ }^{7}$ Moneta, and Rüffer (2009) find evidence of increased synchronization in East Asia. With respect to other regions, Balcilara and Danjub (2010) and Hakura (2009) find regional factors play a minor role in MENA while Kose and Rebucci (2005) and Aiolfi, Catao, and Timmermann (2011) report the growing importance of the regional factors in explaining the degree of output comovement across Central American and Latin American countries, respectively. In related research, Tapsoba (2010) finds that intra-regional trade flows have led to enhanced business cycle comovement in Africa.

Recent research also considers the importance of global and regional (or group) specific factors in explaining business cycles with the help of dynamic factor models involving multiple regions. ${ }^{8}$ Kose, Otrok, and Whiteman (2003) document that there is a significant global factor accounting for national business cycles, but regional factors appear to play smaller roles in a sample of 60 countries and 7 regions over the period 1960-90. Helbling and others (2007) extend this study to 93 countries with different regional configurations and analyze the 1960-2005 period. They document that the regional factors have become more important over time. Karagedikli and

\footnotetext{
${ }^{7}$ Some empirical studies report that increased volume of intra-regional trade flows, especially in the form of intraindustry trade, has been an important factor in explaining the degree of business cycle synchronization in certain regions (for North America, see Swiston and Bayoumi, 2008; for Asia, see Shin and Wang, 2003 and 2004; Shin and Sohn, 2006; Kumakura, 2006; Rana, 2008; and Cortinhas, 2007; for Europe, see Bower and Guillemineau, 2006; and Shin and Wang, 2005). He and Liao (2010) emphasize the importance of the region specific supply factors in explaining the degree of synchronization of Asian business cycles. There also have been some studies focusing specifically on North-South business cycle linkages (Hoffmaister, Pradhan, and Samiei (1998), Kouparitsas (2001) and Akin and Kose (2008)). Hirata, Kim and Kose $(2004,2007)$ present stylized facts of cycles in the MENA region and analyze the sources of these cycles using a small open economy DSGE model.

${ }^{8}$ Di Mauro, Dees, and Mc Kibbon (2008) present a summary of different types of factors affecting global and regional linkages.
} 
Thorsrud (2012) document that regional demand and supply shocks play important roles in explaining national business cycles using a FAVAR model. Mumtaz, Simonelli, and Surico (2011) use a dynamic factor model and report that while the importance of the global factor has declined, regional cycles have become more pronounced over time.

There has been a recent debate on the ability of emerging market economies, especially emerging countries in the Asia-Pacific region, to decouple from a potential slowdown in advanced countries (Helbling and others, 2007). Kose, Otrok, and Prasad (2012) find that there has been some convergence of business cycle fluctuations among the group of advanced economies and among the group of emerging market economies while there has been a concomitant decline in the relative importance of the global factor. They argue that these results partly suggest that there has indeed been a decoupling of business cycles between the advanced and emerging market economies. ${ }^{9}$

\section{Database ANd Methodology}

We introduce the dataset and econometric methodology we employ in this section. Our dataset covers a large number of countries and regions in order to truly account for the evolution of global and regional business cycles. We use a dynamic factor model to be able to capture various sources (global, regional and national) of business cycle fluctuations and explain the evolution of dynamic interactions across different macroeconomic variables in the context of a large dataset.

\section{A. Database}

Our database includes 106 countries partitioned into seven regions: North America (NA), Europe, Oceania, Asia, Latin America and the Caribbean (LAC), Middle East and North Africa (MENA), and Sub-Saharan Africa (SSA). The groupings of countries by region are especially useful to identify a "regional factor" given countries that are geographically close to each other are likely to be affected by similar types of (region-specific) shocks.

The primary source of our data series is the World Bank's World Development Indicators. The database comprises annual data over the period 1960-2010. Real GDP, real private consumption, and real fixed investment correspond to the measures of national output, consumption, and investment, respectively. Using multiple macroeconomic aggregates, rather than just output, allows us to derive more robust measures of global, regional and national business cycles. All variables are measured at constant national prices. We compute the growth rates and remove the mean from each series. Appendix I shows the distribution of countries across seven regions.

In order to examine how global and regional cycles have evolved over time, we divide our sample into two distinct periods - the pre-globalization period (1960-84) and the globalization period (1985-2010). In addition to having roughly equal number of observations in each subperiod, there are three reasons for this demarcation. First, global trade and financial flows have

\footnotetext{
${ }^{9}$ Other studies also consider the decoupling potential of emerging economies using various methodologies (He, Cheung and Chang, 2007; Asian Development Bank, 2007; and Fidrmuc and Korhonen, 2010).
} 
increased markedly since the mid-1980s. ${ }^{10}$ In addition, regional economic linkages have become much stronger during the second period as evidenced by the rapid increase in regional trade agreements as discussed earlier.

Second, after a period of stable growth during the 1960s, the first period witnessed a set of common shocks associated with large fluctuations in the price of oil in the 1970s and synchronized contractionary monetary policies in the major industrial economies in the early 1980s. This demarcation is essential for differentiating the impact of these common shocks from that of globalization on the degree of business cycle comovement. Third, the beginning of the globalization period coincides with a structural decline in the volatility of business cycles in both advanced and developing countries until the financial crisis of 2008-09. ${ }^{11}$

\section{B. Econometric Model}

We employ a dynamic factor model to study the evolution of global and regional business cycles over time. Dynamic factor models have recently become a popular econometric tool for quantifying the degree of comovement among macroeconomic time series as some new estimation methods have been developed to perform factor analysis in large datasets. ${ }^{12}$ The motivation underlying these models is that the covariance or comovement between (observable) macroeconomic time series across countries is the result of a relationship between these variables and a small number of unobservable common factors, which can be thought of as the main forces driving economic activity. These factors can capture common fluctuations across the entire dataset (i.e., the world) or across subsets of the data (i.e., regions). ${ }^{13}$ Dynamic factor models are particularly useful for characterizing the degree and evolution of synchronization in various dimensions without making strong identifying assumptions to disentangle different types of common shocks.

In addition, factor models have the advantage that they are motivated by DSGE models, as was first noted by Sargent (1989) for a general equilibrium model. Recent research on international business cycles shows that one can view the dynamic factor model we employ as a reduced-form solution of a standard open-economy DSGE model as the data generated from that model has a representation of a dynamic factor model (Crucini, Kose, and Otrok, 2011). The typical DSGE model suffers from the curse of dimensionality, limiting the number of shocks and number of driving variables that can be analyzed using such models. The advantages of the dynamic factor

\footnotetext{
${ }^{10}$ As countries have intensified their efforts to liberalize external trade and financial account regimes, there has been a dramatic increase in global trade and financial flows, both in absolute terms and relative to world income, during the globalization period (Kose and Prasad, 2010; Milesi-Ferretti, Strobbe, and Tamirisa, 2010).

${ }^{11}$ For a detailed discussion of this demarcation, see Kose, Otrok, and Prasad (2012). Blanchard and Simon (2001) and Stock and Watson (2005) present evidence for the Great Moderation. We provide a set of sensitivity experiments to check the robustness of our main results to changes in this demarcation.

${ }^{12}$ For explanations of these estimation approaches, see Stock and Watson (2002), Forni and others (2000), and Otrok and Whiteman (1998).

${ }^{13} \mathrm{We}$ do not interpret the factors as representing specific types of shocks such as technology-instead, we view them as capturing the effects of many types of common shocks, including technology, monetary and fiscal policies, world interest rate, and terms-of-trade shocks etc.
} 
model employed here are that it is parsimonious and allows one to consider larger, more interesting datasets than if one was estimating a multi-country DSGE model.

Our dynamic factor model features: (i) a global factor common to all variables (and all countries) in the system; (ii) a factor common to each region; (iii) a country factor common to all variables in each country; and (iv) an idiosyncratic component for each series of each country. Since our primary interest is in comovement across all variables in all countries (or regions), we do not include separate factors for each of the macroeconomic aggregates (including factors in yet another dimension would also make the model intractable for the large number of countries we study). The dynamic relationships in the model are captured by modeling each factor and idiosyncratic component as an autoregressive process.

Specifically, let $\mathrm{Y}_{\mathrm{t}}^{\mathrm{i}, \mathrm{j}, \mathrm{k}}$ denote the growth rate of the $\mathrm{i}^{\text {th }}$ observable variable in the $\mathrm{j}^{\text {th }}$ country of region $\mathrm{k}$. We have three variables (output, consumption and investment) per country (indexed by $i$ ), seven regions (indexed by $k$ ), and 106 countries (indexed by $j$ ). The model can then be written as:

$$
\begin{aligned}
& \mathrm{Y}_{\mathrm{t}}^{\mathrm{i}, \mathrm{j}, \mathrm{k}}=\beta_{\text {global }}^{\mathrm{i}, \mathrm{j}, \mathrm{f}} \mathrm{f}_{\mathrm{t}}^{\text {global }}+\beta_{\text {region } \mathrm{k}}^{\mathrm{i}, \mathrm{j}, \mathrm{f}} \mathrm{f}_{\mathrm{t}}^{\text {region } \mathrm{k}}+\beta_{\text {country } \mathrm{j}}^{\mathrm{i}, \mathrm{j}, \mathrm{f}} \mathrm{f}_{\mathrm{t}}^{\text {country } \mathrm{j}}+\varepsilon_{\mathrm{t}}^{\mathrm{i}, \mathrm{j}, \mathrm{k}}, \\
& \mathrm{f}_{\mathrm{t}}^{\mathrm{m}}=\phi^{\mathrm{m}}(\mathrm{L}) \mathrm{f}_{\mathrm{t}-1}^{\mathrm{m}}+\mu_{\mathrm{t}}^{\mathrm{m}} \text { for } \mathrm{m}=1, \ldots,(1+\mathrm{K}+\mathrm{J}), \\
& \varepsilon_{\mathrm{t}}^{\mathrm{i}, \mathrm{j}, \mathrm{k}}=\phi^{\mathrm{i}, \mathrm{j}, \mathrm{k}}(\mathrm{L}) \varepsilon_{\mathrm{t}-1}^{\mathrm{i}, \mathrm{j}, \mathrm{k}}+v_{\mathrm{t}}^{\mathrm{i}, \mathrm{j}, \mathrm{k}}
\end{aligned}
$$

where $\phi^{\mathrm{i}, \mathrm{j}, \mathrm{k}}(\mathrm{L})$ and $\phi^{\mathrm{m}}(\mathrm{L})$ are lag polynomial operators, $v_{\mathrm{t}}^{\mathrm{i}, \mathrm{j}, \mathrm{k}}$ are distributed $\mathrm{N}\left(0, \sigma_{\mathrm{i}, \mathrm{j}, \mathrm{k}}^{2}\right), \mu_{\mathrm{t}}^{\mathrm{m}}$ are distributed $\mathrm{N}\left(0, \sigma_{\mathrm{m}}^{2}\right)$, and the innovation terms $\mu_{\mathrm{t}}^{\mathrm{m}}$ and $v_{\mathrm{t}}^{\mathrm{i}, \mathrm{j}, \mathrm{k}}$ are mutually orthogonal across all equations and variables in the system. The $\beta$ parameters are called factor loadings and capture the sensitivity of each observable variable to the latent factors (denoted by $f_{t}^{m}$; we have a total of 114 factors ( 1 global factor +7 regional factors +106 country factors) indexed by $m$ ). For each variable, the estimated factor loadings quantify the extent to which that variable moves with the global factor, the regional factor, and the country-specific factor, respectively. The lag polynomials can in principle be of different order; however, for simplicity and parsimony, we restrict them to be AR(3) for each factor and idiosyncratic term. Since we are using annual data, this should capture most spillovers, either contemporaneous or lagged, across variables and countries.

The model is estimated using Bayesian techniques as described in Kose, Otrok, and Whiteman (2003) and Otrok and Whiteman (1998). There are two related identification problems in the estimation of the model given by equations (1)-(3): neither the signs nor the scales of the factors and the factor loadings are separately identified. We identify the signs by requiring one of the factor loadings to be positive for each of the factors. In particular, we impose the conditions that the factor loading for the global factor is positive for U.S. output; that country factors have positive factor loadings for the output of each country; and factors for each region have positive 
loadings for the output of the first country listed in each region in Appendix I. ${ }^{14}$ Following Sargent and Sims (1977) and Stock and Watson (1989), we identify the scales by assuming that each $\sigma_{\mathrm{m}}^{2}$ equals a constant. The constant is chosen based on the scale of the data, so that the innovation variance is equal to the average innovation variance of a set of univariate autoregressions on each time series. The results are not sensitive to this normalization. ${ }^{15}$

There is a rich literature on large dynamic factor models that is closely related to our work (e.g., Forni, Hallin, Lippi, and Reichlin, 2000; Stock and Watson, 2002; Doz, Giannone, and Reichlin, 2008). Our approach is related to this literature, but a virtue of our methodology is that we can easily employ a factor structure where there are simultaneously estimated factors using large and small cross-sections of the data without relying on asymptotics. In our parametric approach, we can estimate factors for small cross-sections of the data (e.g., individual countries) conditional on larger cross-sections (i.e., global and regional factors).

\section{Variance Decompositions}

To measure the importance of each factor for explaining the volatility of macroeconomic aggregates, variance decompositions are calculated. The formula for the variance decomposition is derived by applying the variance operator to each equation in the system. This provides an empirical assessment of how much of a country's business cycle fluctuations are associated with global fluctuations or fluctuations among countries in each region. We estimate the share of the variance of each macroeconomic variable attributable to each of the three factors and the idiosyncratic component. With orthogonal factors, the variance of the growth rate of the observable quantity $\mathrm{Y}_{\mathrm{t}}^{\mathrm{i}, \mathrm{j}, \mathrm{k}}$ can be written as follows:

$$
\operatorname{var}\left(\mathrm{Y}_{\mathrm{t}}^{\mathrm{i}, \mathrm{j}, \mathrm{k}}\right)=\left(\beta_{\text {global }}^{\mathrm{i}, \mathrm{j}, \mathrm{k}}\right)^{2} \operatorname{var}\left(\mathrm{f}_{\mathrm{t}}^{\text {global }}\right)+\left(\beta_{\text {region k }}^{\mathrm{i}, \mathrm{j}, \mathrm{k}}\right)^{2} \operatorname{var}\left(\mathrm{f}_{\mathrm{t}}^{\text {region k }}\right)+\left(\beta_{\text {country } \mathrm{j}}^{\mathrm{i}, \mathrm{k}}\right)^{2} \operatorname{var}\left(\mathrm{f}_{\mathrm{t}}^{\text {country } \mathrm{j}}\right)+\operatorname{var}\left(\varepsilon_{\mathrm{t}}^{\mathrm{i}, \mathrm{j}, \mathrm{k}}\right)
$$

Then, the fraction of volatility due to, say, the regional factor $\mathrm{k}$ would be:

$$
\frac{\left(\beta_{\text {region } \mathrm{i}, \mathrm{k}}^{\mathrm{i}}\right)^{2} \operatorname{var}\left(\mathrm{f}_{\mathrm{t}}^{\text {region k}}\right)}{\operatorname{var}\left(\mathrm{Y}_{\mathrm{t}}^{\mathrm{i}, \mathrm{j}, \mathrm{k}}\right)}
$$

\footnotetext{
${ }^{14}$ The sign restriction is simply a normalization that allows us to interpret the factors in an intuitive way. For instance, we normalize the factor loading for the U.S. output growth on the global factor to be positive. This implies that the global factor falls in 1974, 1981, 1992, and 2009 consistent with the fact that the United States and most other countries experienced recessions in those years.

${ }^{15}$ The procedure draws the regional factor conditional on the global factor, and then the country factor conditional on the global and regional factors. This assumes an orthogonality between the global and regional factor innovations. The model assumes that the country factor innovations are orthogonal to each other. Even though the factors are uncorrelated, samples taken at each pass of the Markov chain will not be, purely because of sampling errors. To ensure adding up, we orthogonalized the sampled factors, ordering the global factor first, the regional factor second, and the country factor third. Our simulations suggest that the order of orthogonalization has little impact on the results. In particular, all of the results remain qualitatively similar under alternative orderings, and the quantitative differences are small.
} 
These measures are calculated at each pass of the Markov chain; dispersion in their posterior distributions reflects uncertainty regarding their magnitudes.

\section{How Important Are Regional CyCles (1960-2010)?}

Before analyzing the evolution of global and regional business cycles over time, we first consider the sources of business cycle fluctuations over the full sample period. As a summary measure of the importance of the factors, we present the average variance shares (within the relevant regions of countries) attributable to each factor for the world and seven regions defined earlier. We do not report standard errors for these cross-country averages, but will do so later when we look at individual country results. ${ }^{16}$ As we discussed in Section II, most of the literature on regional business cycles have studied output as the main indicator of cyclical activity. We also consider the sources of cycles in consumption and investment.

We briefly summarize the major results from the analysis of variance decompositions for the period 1960-2010. First, the global factor plays an important role in explaining business cycles implying that there exists a world business cycle. Second, regional factors are also significant drivers of business cycles. The regional factor on average accounts for a slightly larger share of variance of output and investment than does the global factor. Regional cycles tend to be more pronounced especially in regions with relatively stronger intra-regional trade and financial linkages. As discussed in the next section, this result is mainly driven by the emergence of the regional cycles in the second sub-period (1985-2010). Third, the average degree of synchronization of business cycles in individual countries with the rest of the world, measured by the sum of the variance shares explained by the global and regional factors, is quite high. In addition, a larger fraction of output variation is captured by the global and regional factors than that of consumption variation implying that there are still unexploited global and regional risksharing opportunities.

\section{A. Global and Regional Cycles}

How important is the global business cycle? As Table 1 shows, the global factor explains a significant fraction of business cycle fluctuations in all three macroeconomic variables over the period 1960-2010, implying that there is indeed a sizeable world business cycle. The global factor on average accounts for 10 percent of output growth variation among all countries in the sample. It also explains roughly 9 percent and 5 percent of the volatility of growth rates of consumption and investment, respectively. Although the variance shares attributed to the global factor appear to be small at first sight, it is important to remember that the global (common) factor across the three macroeconomic aggregates is for a very large and diverse set of countries.

The global factor tends to be important in each region, but on average it plays a more dominant role in explaining business cycles in advanced country regions (North America and Europe) with stronger intra-regional trade and financial linkages than those regions with emerging market and developing economies (Asia, LAC, SSA, and MENA). The global factor on average explains

\footnotetext{
${ }^{16}$ We also calculated the median (rather than mean) variance shares attributable to each factor for the full sample and each region. As these lead to qualitatively similar conclusions, we only report results using means.
} 
about 17 (27) percent of output fluctuations in North America (Europe). In contrast, in the latter group of regions, the global factor explains between 5 percent (in SSA) to 9 percent (in Asia) of output fluctuations. The global factor is also associated with a substantial share of the variance in consumption and investment growth among regions of advanced countries, accounting on average for about 25 percent and 12 percent of the total variance of these variables, respectively. These shares are also much larger than the corresponding numbers for other regions.

How important are regional cycles? The results indicate that the regional factor on average plays a slightly more important role than the global factor in explaining output fluctuations. Table 1 shows that the regional factor accounts for about 13 percent of output growth fluctuations in the full sample. The fraction of output variance explained by the regional factor is larger than that of the global factor in three of the seven regions. The regional factor, like the global factor, tends to be more important for advanced country regions. On average, it accounts for about 34 percent and 22 percent of output growth fluctuations in North America and Europe, respectively. While the regional factor explains a relatively smaller share of variance of output for Oceania, SSA and MENA, it explains a significant part of variation for Asia and LAC.

The regional factor also appears to be a major driver of business cycles in consumption and investment. While it accounts for only a slightly small share of consumption variation than does the global factor, its contribution to investment volatility is two times larger than that of the global factor. In six out of the seven regions, the regional factor is more important than the global one in explaining the volatility of consumption and investment.

We also examine the overall synchronization of global business cycles by using the sum of the variance contributions of the global and regional factors. The rankings of different regions remain much the same, although the magnitudes are of course larger. Among North America and Europe, the total contribution of these two factors averages between 48 and 50 percent for output, 34 and 45 percent for consumption, and 35 and 40 percent for investment. For other regions, the average for output variance is between 7 percent (for SSA) and 30 percent (for Asia).

Our results also indicate that the factor loadings associated with output and consumption growth on the global factor are positive for 70 percent and 83 percent of countries, respectively (i.e., the posterior distributions of the factor loadings have very little mass in symmetric intervals about zero). These findings imply that positive developments in the U.S. economy are generally associated with higher growth in the rest of the world since the global factor is identified by a positive factor loading for U.S. output growth.

\section{B. Country-Specific Cycles}

We next turn our attention to the roles played by country and idiosyncratic factors in explaining business cycles. Both of these play important roles in driving business cycles around the world (Table 1). The country factor is on average more important in explaining output variation than is the idiosyncratic factor ( 41 percent vs. 34 percent), but the reverse is true for fluctuations in consumption ( 34 percent vs. 48 percent) and investment ( 27 percent vs. 56 percent). Given that consumption and investment series tend to have larger measurement problems than those of 
output, it is normal that fluctuations in consumption and investment exhibit larger idiosyncratic components.

With respect to different regions, the results indicate that as countries get more exposed to global trade and financial flows and establish stronger intra-regional economic linkages, the global and region-specific factors increasingly become more relevant in explaining national business cycles at the expense of the country and idiosyncratic factors. For example, country and idiosyncratic factors together explain about 50 percent of output variation in North America and Europe, but their share is on average more than 80 percent in five other regions.

How different are the factors explaining fluctuations in output and consumption? The total contribution of the global and regional factors is greater for output than for consumption for the sample as a whole and also for each region. Indeed, Figure 1 shows that this is true even when we look at the global and regional factors by themselves. This implies that, on average, countryspecific and idiosyncratic factors play a more important role in explaining consumption fluctuations than in the case for output fluctuations. This result is very similar to a well-known stylized fact in the literature that, contrary to the predictions of conventional theoretical models of international business cycles, output is more highly correlated across countries than consumption (Backus, Kehoe, and Kydland (1995) refer to this as the "quantity anomaly").

As one would expect, the contribution of the idiosyncratic factor in regions populated with relatively less developed countries is greater than that of any other factor. This is true for all variables, but especially so for investment, where on average the idiosyncratic factor accounts for 79 percent of fluctuations in SSA and 57 percent of fluctuations in MENA. This result implies that investment fluctuations in these regions do not appear to be influenced much by either national or global business cycles.

\section{Global, Regional, and Country Factors}

We also study the temporal evolution of the global, regional and country factors. These factors are able to capture the main cyclical episodes of the past fifty years. For example, the estimated global factor closely matches the major peaks and troughs observed in the global business cycle, including the recessions in 1974-75, the early 1980s, the early 1990s, the slowdown in the early 2000s, and the recent global recession. ${ }^{17}$ Moreover, there is considerable overlap in the evolution of the global factor and U.S. growth, especially during U.S. recessions.

Regional factors also reflect some of the major region specific episodes. For example, the Asian regional factor captures the Asian financial crisis, the LAC factor is consistent with the debt crisis of the early 1980s, and the North American and European factors exhibit the sharp contraction associated with the global financial crisis of 2008-09. We also examine relationships among the global factor, regional factors, country factors, and output in some select countries. These factors play different roles at different points in time and around the globe. In some

\footnotetext{
${ }^{17}$ Specifically, our global factor model captures the global recessions of 1974, 1982, 1991, and 2009 identified by Kose, Loungani and Terrones (2013).
} 
episodes, the country factor is more strongly reflective of domestic economic activity, while in others the domestic growth appears to be influenced by movements in the global and/or regional factors.

Do global business cycles exhibit more persistent behavior than do the regional and national cycles? In order to measure persistence of cycles, we calculate the first-order autocorrelation of each factor. The global factor has large and positive autocorrelation (0.60), and compared to the autocorrelations of the regional factors and most of the country factors, it is much more persistent. The average persistence is about 0.20 for regional factors while it is around 0.10 for country factors. These results suggest that the global factor accounts for most of the persistent (or low frequency) comovement across countries whereas the global and regional factors appear to be responsible for the higher frequency comovement. ${ }^{18}$

\section{Business CyCles: Regionalization OR Globalization? (1960-84 AND 1985-2010)}

We have briefly documented in our introduction that there has been a dramatic increase in global trade and financial flows over the past 25 years. This period has also witnessed a rapid growth of intra-regional trade and financial linkages in some regions. In light of these observations, it is natural to study the evolution of the roles played by the global and regional factors in explaining business cycles over time. We estimate our dynamic factor model over two periods, 1960-84 and 1985-2010, for this purpose. As we have already discussed in Section II, there are a number of good reasons justifying the selection of these two sub-periods.

By estimating the model over two sub-periods, we allow the model parameters, such as the factor loadings and those that determine the structure of propagation of shocks, to vary across time. This naturally yields a different variance decomposition for each sub-period. It is important to note that the estimate of the global factor itself is similar whether it is estimated over the full sample or over sub-samples. This is not surprising as the index of common activity in a period should not be affected by data many periods away (Stock and Watson, 2009).

In this section, we first analyze the evolution of the importance of various factors in explaining output variation over time. Next, we consider how the global and regional cycles in consumption and investment have evolved over time. Before delving into the details, we briefly summarize the major results of this section. First, the results suggest that the global factor on average has played a significant role during the full sample, but its role has become less important in the second period. Second, regional factors have become more influential in explaining business cycles over time. These factors account for a much larger variation of business cycle volatility especially in regions where intra-regional trade and financial linkages have increased substantially during the second sub-period. Our findings indicate that while both global and regional factors are significant drivers of business cycles, regional factors increasingly play a more important role.

\footnotetext{
${ }^{18} \mathrm{We}$ do not present the factors and results with respect to their persistence here. They are available from the authors upon request.
} 


\section{A. Evolution of Global and Regional Cycles}

Tables 2-3 show the variance decompositions based on models estimated separately for the preglobalization (1960-84) and globalization (1985-2010) periods, respectively. A number of commentators argue that because of the forces of globalization, national business cycles should have become more synchronized over time. Contrary to these popular arguments, the average contribution of the global factor to output fluctuations registers a sizeable decline in the second sub-period, from 13 percent to 9 percent for the full sample of countries. The same pattern holds for consumption fluctuations while the importance of the global factor registers a slight increase in fluctuations in investment (Figure 2).

These patterns also hold up and are in fact stronger in most cases when we evaluate the variance decompositions of output fluctuations for different regions (Figure 2). The global factor appears to play a smaller role in explaining business cycles in the second sub-period in all regions except North America and Oceania. The share of the variance of output due to the global factor increases from 22 (12) percent to 30 (21) percent in North America (Oceania) in the second period.

In contrast, the regional factor has on average played an increasingly more dominant role in explaining business cycles over time (Tables 2-3 and Figure 3). For example, the average share of the variance of output attributed to the regional factor has risen from 11 percent to 19 percent during the second period. These patterns are particularly strong among the following regions: North America, Europe, Oceania, and Asia regions. In particular, in the second sub-period, the regional factor has accounted for roughly one-third of output fluctuations in North America and Asia, and 40 percent in Europe, 20 percent in Oceania. In a similar fashion, the regional factor for SSA and MENA has played a more important role in the second period, but the increase in the variance share of output attributed to the regional factor is much smaller in these regions. In LAC, the importance of the regional factor does not change much over the two sub-periods.

How can we explain these results? It is useful to answer this question in two steps. First, the decline in the importance of the global factor supports the interpretation that the strong business cycle synchronization observed during the 1970s and early 1980s reflected large common disturbances - the two oil price shocks - and the effects of correlated disturbances in the major advanced countries, notably the disinflationary monetary policy stance in the early 1980s. Although the latest financial crisis can also be seen as a massive global shock, its full impact on our variance decompositions has probably yet to be fully realized (as we have only three years of observations associated with the crisis). ${ }^{19}$ Moreover, as we indicated in our introduction, there was substantial variation in the performance of different regions during the latest crisis. These developments have collectively led to an overall decline in the importance of the global factor in explaining business cycles during the globalization period.

Second, there has been on average an increase in the importance of regional factors. In particular, regional linkages have become much more significant in regions where intra-regional trade and

\footnotetext{
${ }^{19}$ To examine the implications of the post-crisis period on our findings, we extend our sample to 2015 using forecasted series in Section VI.C, but our headline results do not change.
} 
financial flows have increased substantially after the mid-1980s (North America, Europe, Oceania, and Asia). These regions have undertaken substantial steps to strengthen regional economic linkages during the second sub-period. For example, intra-regional trade and financial linkages have registered significant growth over the past quarter century in the North American region where the process of economic integration started in the mid-1980s and culminated with the ratification of the NAFTA in $1994 .{ }^{20}$ During the past decade, intra-regional trade flows accounted for nearly 55 percent of total trade while intra-regional financial assets were about 20 percent of total assets in the North American region. ${ }^{21}$

One of the greatest regional integration projects of history took place in Europe with the eventual establishment of the European Union and creation of euro area. Intra-regional trade flows have constituted roughly 75 percent of total trade in Europe during the past decade. Intra-regional asset holdings went up from 55 percent to roughly 75 percent of total assets in Europe over the same period.

Regional integration in Asia has been mainly driven by the ASEAN (Association of South East Asian Nations) and complemented by a number of bilateral regional arrangements (Plummer, 2006). The region has seen a rapid increase in intra-regional trade and financial flows especially over the past decade. The share of intra-regional trade flows was around 55 percent over the past decade while intra-regional asset holdings increased to more than 5 percent of total assets. In the case of Oceania, the Australia-New Zealand Closer Economic Relations Agreement in 1983 marked the beginning of a period of rapid growth in intra-regional trade and financial linkages (Gonuguntla, 2010). ${ }^{22}$

The nature of trade has also changed in these four regions over time. One of the major driving forces of the rapid growth in regional trade flows has been the acceleration of intra-industry trade. The surge in intra-industry trade linkages has been associated with vertical specialization of trade (Yi, 2003; De Backer and Yamano, 2007) which is associated with a higher degree of business cycle synchronization (di Giovanni and Levchenko, 2010; Ng, 2010). Moreover, during the second sub-period, countries in these regions have increased the pace of diversification of their industrial (and trade) bases. This has been accompanied by a greater degree of sectoral similarity across countries within regions further contributing to the increase in the degree of business cycle synchronization (Imbs, 2004; Kose and Prasad, 2010).

The evolution of global and regional cycles is of course affected by various types of shocks, in addition to increased trade and financial integration. For example, common shocks, such as abrupt, unexpected changes in commodity prices or sharp fluctuations in asset prices in the major financial centers, can lead to a higher degree of synchronization of global or regional business

\footnotetext{
${ }^{20}$ Mexico and the United States undertook trade negotiations on specific sectors and reached framework agreements in 1985, 1987, and 1989. Mexico and Canada started discussions toward closer bilateral trade relations in 1990. Canada and the United States began negotiations for a free trade area in 1986 and launched the Canada-U.S. Free Trade Agreement (CUSFTA) in 1989 (Kose, Meredith, and Towe, 2005; Lederman, Maloney, and Servén, 2005).

${ }^{21}$ Statistics for intra-regional financial assets are based on the IMF's Coordinated Portfolio Investment Survey.

${ }^{22}$ See Devereux and others, (2011) and Waysand, Ross, de Guzman (2010) for the evolution of financial integration in Asia and Europe, respectively. See Petri, Plummer, and Zhai (2011) and Arribas, Pérez, and Tortosa-Ausina (2011) analyze the growth of trade linkages in Asia and Europe, respectively.
} 
cycles. Both the global and regional cycles can also be affected by cross-border spillovers of disturbances originating in a large economy. Moreover, global and regional business cycles can emerge simply because of correlated shocks, such as shocks associated with the implementation of similar policies. It is easy to see how these types of shocks have been influential in some of the regions that have experienced more pronounced regional cycles. For example, while the implementation of similar policies has contributed greatly to the convergence of national cycles in Europe over the period 1985-2010, cross-border spillovers originating in the United States and China have probably been important in explaining regional cycles in North America and Asia, respectively.

Not surprisingly, the importance of regional factors in explaining business cycles in less developed regions, such as SSA and MENA, which are also the regions relatively less exposed to the forces of globalization, has registered only a slight increase between the two periods. In LAC, the importance of the regional factor does not change much over the two sub-periods. This could reflect the region specific developments, such as the buildup in external debt, the subsequent debt crises in the early 1980s, and regional contagion following the financial crisis of the 1990 s and early 2000 s.

The total contribution of global and regional factors together to output fluctuations has, on average, has recorded a small increase from 24 percent in the first sub-period to 29 percent in the second sub-period (Figure 4). This is of course the consequence of a substantial increase in the relative importance of the regional factor. Since the total contribution of global and regional factors is a measure of the extent of co-movement across national business cycles, these results show that while there is some evidence implying that business cycles have become more synchronized over time, the increase in the change of variance explained by the global and regional factors is relatively small. However, as we present in Section VI, this small increase is entirely driven by the period of highly synchronized cyclical activity due to the global financial crisis of 2008-09.

How do our findings compare with the results in the literature? Most of the earlier studies have typically focused on just output or industrial production fluctuations and limited their analysis to specific regions. However, as we briefly discuss in Section II, these studies often report conflicting results. For example, some recent papers document that there is a distinct European business cycle while others argue the opposite (De Haan, Inklaar, Jong-a-Pin, 2008). ${ }^{23}$ Other studies find regional cycles specific to East Asia and North America. Some of these studies resort to simple correlations (over much shorter time-periods and smaller samples than ours here) and report that business cycles within certain regions have become more correlated over time. Most of the studies are unable to properly account for the extent of regional business cycle comovement since they mostly rely on bilateral correlations, which are fraught with a number of problems. For example, deriving summary correlation measures from large datasets requires one to take averages across the estimated correlations, a procedure that can mask the presence of comovement across a subset of the data. One way to reduce the number of bivariate correlations

\footnotetext{
${ }^{23}$ de Haan, Inklaar, and Jong-A-Pin (2008) present a survey of the rich literature on business cycle synchronization in the euro area. They argue that this literature has been unable to produce conclusive results on the convergence of cycles in the euro area because of differences in data series and methodologies employed.
} 
is to specify a country or weighted aggregate to serve as the reference against which other countries' correlations are computed. However, changes in the reference country/aggregate often lead to significantly different results. Such weighting schemes also inevitably give rise to questions about the weights and concerns that a large county may dominate the global/regional business cycle by virtue of its size when, in fact, that country may be disengaged from other countries. Moreover, static correlations cannot capture the dynamic properties of the data, such as autocorrelations and cross-autocorrelations across variables.

Factor models obviate these problems. They do not require one to average across variables or define a "numeraire" country. Instead, they identify the common component and, at the same time, detect how each country responds to that component. More importantly, factor models are flexible enough that multiple factors can be specified in a parsimonious way to capture the extent of synchronicity across the entire dataset as well as the synchronicity specific to subsets of the data, such as regions. Furthermore, since the factors are extracted simultaneously, we can assign a degree of relative importance to each type of factor.

Our findings are consistent with the results reported by studies that employ dynamic factor models. For example, Karagedikli and Thorsrud (2012) and Mumtaz, Simonelli, and Surico (2011) also report that regional business cycles have become more pronounced over time. We focus on a much larger dataset than these studies do. ${ }^{24}$ Our large dataset, which allows us to consider the synchronization of cycles in many regions, our long sample, which covers a substantial period of the recent era of globalization, and our demarcation of the pre-globalization and globalization periods are essential in enabling us to identify the emergence of regional cycles during the second sub-period. ${ }^{25}$

\section{B. Synchronization of Cycles in Consumption and Investment}

We next assess the evolution of variance shares attributable to different factors in explaining consumption and investment fluctuations. For the world as a whole, the increase in the variance contribution of regional factors to consumption fluctuations is on average about 6 percentage points (from 8 percent to 14 percent), but the joint share of the global and region-specific factors

\footnotetext{
${ }^{24}$ Karagedikli and Thorsrud (2012) employ a FAVAR model to analyze the evolution of activity (GDP and IP) and price (CPI and PPI) factors over time. They use the quarterly data of 31 countries covering four regions (Asia, Europe, North and South America) over the period 1990:1-2009:4. They document that regional demand and supply shocks play important roles in explaining national business cycles. Mumtaz, Simonelli, and Surico (2011) analyze the evolution of global and regional cycles in GDP and inflation for 35 counties in five regions (Asia, Europe, Oceania, North and South America) over the period from the mid 1800s to 2007 using a dynamic factor model. They find that while the importance of the global factor has declined, regional cycles have become more pronounced in all regions except North America during the period 1985-2007.

${ }^{25}$ Although our findings on the surface appear to be different from those of Kose, Otrok, and Whiteman (2003), they are indeed consistent. The new study provides a nuanced view about the existence (and emergence) of regional cycles. The differences between our findings and theirs are primarily driven by the differences in the selection of regional groupings, the number of countries in the sample, and most importantly the time period covered. The regional cycles have become more important in the 1985-2010 period most of which was not included in the sample in Kose, Otrok, and Whiteman (2003) which ends in 1990. Moreover, our use of a larger sample (and larger subsamples in most regions) allows us to draw a sharper contrast across regions in terms of their exposure to the global economy.
} 
has not changed much (Tables 2-3). For the North American, European, Oceanian, and Asian regions, the two common factors jointly account for a substantially higher share of consumption fluctuations in the second sub-period whereas, for SSA and LAC, the share of these factors has on average declined over time. The share of consumption variation due to the country and idiosyncratic factors is much smaller in North America, Europe and Oceania than those of others. In particular, the average variance of consumption explained by these two factors is about 54 percent in these three regions, but it is 83 percent in the other four regions.

These findings indicate that the three regions populated mostly by advanced countries have been able to use globalization relatively more effectively to share national consumption risk. In addition to their relatively more advanced levels of financial development, these regions are more exposed to global trade and financial linkages in the second sub-period. These results are confirmed by some recent studies as well (Sorensen, Wu, and Zhu, 2007; Kose, Prasad, and Terrones, 2009). On the other hand, regions with relatively less developed domestic financial markets and with less exposure to cross-border linkages are probably at earlier stages of utilizing this benefit of globalization as their consumption fluctuations are still closely tied to national cycles.

The share of investment variance attributable to the global and regional factors increases for the world and for all the regions in the second sub-period. The variance of investment growth due to the global and regional factors rises from 16 percent in the first sub-period to 24 percent in the second sub-period for the full sample. These two factors on average account for 51 percent of investment variation in North America, Europe and Oceania and 16 percent in the other four regions in the second sub-period. One interpretation of this finding is that fluctuations in investment have been becoming more synchronized over time, especially in regions with more pronounced global and intra-regional linkages.

However, these findings imply different outcomes than those offered by the predictions of standard international business cycle models. The basic theory implies that stronger trade and financial linkages translate into lower investment correlations across countries. Specifically, when restrictions on capital and current account transactions are relaxed in these models, capital and other resources rapidly move to countries with more favorable technology shocks because of the standard "resource shifting" effect in standard business cycle models (see Backus and others, 1995; Ravn and Mazzenga, 2004; and Heathcote and Perri, 2002). ${ }^{26}$

The results with respect to the synchronization of consumption and investment fluctuations suggest that the data paint a different picture than do the standard business cycle models. In particular, the forces of globalization have not translated into an increase in the degree of risk sharing achieved by all of the regions in our sample as would be expected on the basis of standard models. In addition, contrary to the predictions of these models, the importance of

\footnotetext{
${ }^{26}$ Some studies present models that are able to produce results consistent with the dynamics of investment we report here. In Head's (2002) model, cross-country correlations of investment are positive because of increasing returns to the worldwide variety of intermediate goods. Heathcote and Perri (2004) show that changes in the correlation structure of shocks and extent of the portfolio diversification affect cross-country investment correlations in international business cycle models.
} 
global and regional factors for investment fluctuations has risen during the period of globalization, implying a higher degree of cross-country comovement of fluctuations in this variable.

\section{SENSITIVITY EXPERIMENTS}

We now analyze the robustness of our main findings considering a variety of sensitivity experiments. Specifically, we conduct four types of experiments to address the following issues: the correspondence between the aggregate results and those at the country level; implications of alternative break points and changes in the composition of regions; effects of crises; and the dynamic relationship between the global factor and observable variables. We discuss below the results of each of these experiments in turn.

\section{A. Country-Specific Results}

Do the averages we presented so far accurately reflect the sources of business cycle variation at the country level? In order to address this question, we examine the relative contributions of global and regional factors to each of the macroeconomic variables for each country. Figures 5-6 present the relative contributions of the global and regional factors to output fluctuations in individual countries in four regions: North America, Europe, Asia and Oceania. These regions are especially interesting cases as they experience a substantial increase in the importance of the regional factor in the second period. Moreover, the global factor becomes less influential in all of these regions except North America. We present the contributions of the global and regional factors separately for the two sub-periods. We also show the posterior coverage intervals (of length two standard deviations) around the posterior means of the estimated variance contributions. Non-overlapping posterior coverage intervals indicate statistically significant changes between the two periods.

The variance contribution of the global factor drops from the first period to the second for 16 countries, remains unchanged for 16 others, and increases for only 7 countries, for North America, Europe, Asia and Oceania. In the case of North America, the global factor becomes more important in the United States, but it does not become significantly more influential in Canada and Mexico. When we examine the importance of the regional factor over time, we observe a different pattern: it goes up for 27 countries, stays unchanged for 8 , and declines for 4 for these four regions.

These patterns are quite similar when we look at the three other regions as well, with the relative importance of the global factor going up for only 12 countries but declining for 27 of them. The relative importance of the regional factor, by contrast, rises for 23 and falls for 15 countries. There is no significant change in the share explained by the global or regional factors in other countries. For the world as a whole, the share of the global factor rises in the second sub-period in 21 countries, remains unchanged in 42 countries, and declines in 43 countries. For the world as a whole, the share of the regional factor rises in the second sub-period in 50 countries, remains unchanged in 37 countries, and declines in 19 countries. These findings indicate that our headline 
results with respect to the evolution of the importance of the global and regional factors over time are confirmed by the country-specific analysis. ${ }^{27}$

\section{B. Demarcation of Time and Configuration of Regions}

We next analyze the robustness of our results to alternative break points in the sample and changes in configurations of regions. In Section III, we have already discussed a variety of reasons why 1985 is a logical break point to analyze the evolutionary changes in the roles played by global and regional factors in explaining business cycles. We also estimated the model for alternative sample periods using 1983 and 1987 as break points. The results for these subsamples lead to qualitatively similar conclusions (Table 4). In addition, the individual variance decomposition patterns documented in Figures 5-6 remain essentially the same, confirming that our results do not hinge on the exact break date. ${ }^{28}$

We also analyze how our main results change in response to variations in the country composition of regions. We consider three separate experiments involving the following changes: moving Mexico from North America to the LAC region; moving Turkey from Europe to the MENA region; and moving Israel from MENA to Europe. Although these experiments slightly change the quantitative results, our qualitative findings remain intact. ${ }^{29}$

\section{Crises and Synchronization}

It is natural to study whether our results are driven by crises since periods of crises often coincide with highly synchronized business cycles in regions (or groups of countries). The crises episodes can potentially bias our findings and lead to changes in the shares of variance captured by different types of factors. During the second sub-period, the most prominent widespread crises have of course been the Asian financial crisis of 1997-98, which directly affected a handful of countries in the region, and the global financial crisis of 2008-09, which led to sharp contractions in a number of advanced countries.

We undertake three experiments to study the impact of these periods. First, we exclude the four countries (Korea, Malaysia, Philippines, Thailand) directly affected by the Asian crisis from our sample and re-estimate the model. Second, we use the original model estimates and then compute the variance contributions of different factors for the Asian region excluding the crisis countries. Finally, to account for the impact of the global financial crisis, we consider two

\footnotetext{
${ }^{27}$ If we focus on the absolute changes in the importance of global and regional factors in explaining output variation, our results indicate that the share of the global factor rises in the second sub-period in 39 countries and declines in 67 countries. Similarly, the share of the regional factor rises in the second sub-period in 69 countries and goes down in 37. Detailed results are available from the authors upon request.

${ }^{28} \mathrm{We}$ also conduct some formal tests to examine whether there is a structural break in the sample. In particular, we perform some univariate break tests for a variance break following Stock and Watson (2005). We use the Andrews (1993) test for a break in either the unconditional variance or the persistence of each time series at an unknown date. Searching over the middle two-thirds of the full time span of the sample, we find that the majority of those time series that have a break in their unconditional variance experience that break in or before 1984. A similar test for a break in the autoregressive parameter of a univariate AR(1) model indicates that a substantial share of the series that have a break have it by 1984 .

${ }^{29}$ The details of sensitivity results reported in this sub-section are available from the authors upon request.
} 
complementary experiments by excluding the last three years from the second sub-sample (2008-10) and by extending the sample to 2015 using forecasts of the data for the 2011-15 period.

The results of these experiments indicate that our headline findings are preserved. However, the last experiment suggests that the global financial crisis affects some of our other results (Table 5). In particular, we reported in the previous section a small increase in the total contribution of global and regional factors together to output fluctuations in the second sub-period. This finding appears to be driven by the global financial crisis. If the second sub-period includes only the 1985-07 period, the variance share due to the global factor decreases more in the second subperiod leading to a slight decline in the total variance share of output due to the global and regional factors.

We also analyze the possible effects of the global financial crisis on our results considering a longer time period. Specifically, we extend our sample by including forecasted values of the three macroeconomic variables for the period 2011-15 (these forecasts are based on the IMF's World Economic Outlook, April 2011). The results point to similar conclusions we get from the 1985-2010 sample.

\section{Dynamics of the Global Factor}

Although our factor structure is dynamic, the observable variables depend on the factors only contemporaneously in the model. If the global factor has lagged effects on the observables, it is possible that our model understates the importance of the global factor. Given the dynamic nature of our factors, we think that these effects are likely to be small. Moreover, since we use annual data, the lagged effect would have to be fairly slow moving to have an impact on the results. We address the potential for lagged effects by regressing each observable variable on the global factor and two lags of the factor. The coefficients on the first lag were significant for only a small fraction of the time series we have. ${ }^{30}$ We conclude that lagged responses are of minor importance and would not affect our main conclusions about the relative importance of the global and regional factors.

\section{CONCLUSION}

We have analyzed the evolution of global and regional business cycles over the past five decades. Our results indicate that regional business cycles have increasingly become more pronounced especially in regions where intra-regional trade and financial linkages have registered rapid growth since the mid-1980s. In particular, the regional factor has explained a larger fraction of business cycle variation in the North American, European, Oceanian, and Asian regions over the past twenty-five years. Surprisingly, the importance of global factor has

\footnotetext{
${ }^{30}$ The first lag is significant in only 12, 10, 13 (out of 106) time series of output, consumption, and investment, respectively. Focusing on the North America, Europe, Asia and Oceania regions, the first lag is significant in only 3 , 4, 6 (out of 39) time series for output, consumption, and investment, respectively. The second lag is of similar importance, with a significant coefficient in 9, 7, 16 percent of the time series for output, consumption, and investment, respectively.
} 
declined over time. The total contribution of common factors (global and regional) has not registered a significant change implying that there has been no change in the degree of international business cycle synchronicity during the past quarter century.

These results present a different interpretation of the impact of globalization on the synchronization of business cycles. Most commentators argue that globalization of trade and financial linkages have led to the globalization of business cycles as well. Contrary to these popular arguments, regional factors, rather than global ones, have become the driving forces of business cycles during the recent era of globalization. This has led to the emergence of regional business cycles.

A wide range of developments at the regional level can explain the emergence of regional cycles. For example, the dramatic increase in intra-regional trade and financial flows fueled by regional integration initiatives can promote a higher degree of business cycle synchronization across countries in a region. Regional business cycles can also emerge because of the prominent role of region-specific shocks driven by the implementation of similar policies in a region. Moreover, cross-border spillovers of disturbances originating in a large country in a region can translate into more synchronized national business cycles in that region.

There are a number of interesting research questions to be explored in future studies. We briefly mention three of them here. First, we documented the emergence of regional cycles and provided some intuitive arguments explaining their emergence, but it is important to go a step beyond and analyze the main driving forces of the global and regional cycles. Do we observe the emergence of regional cycles because of the growth in intra-regional trade and financial linkages, or because of the more prominent role played by region-specific shocks, including technology and policy disturbances?

The second interesting issue to explore is the evolution of financial cycles. Although financial cycles appear to be highly synchronized across countries, they do not translate into highly synchronized business cycles at the global level. What are the major factors explaining the globalization of financial cycles while business cycles have been becoming more regionalized? Third, it would be very useful to consider the policy implications of the emergence of regional cycles. As recent developments in Europe have clearly demonstrated, we need to have a better understanding of region-wide policies for the volatility of synchronization of cycles. We plan to address some of these issues in our future research. 


\section{REFERENCES}

Abeysinghe, T. and K. Forbes, 2005, "Trade Linkages and Output-Multiplier Effects: a Structural VAR Approach with a Focus on Asia," Review of International Economics, Vol. 13, No. 2, pp. 356-75.

Aiolfi, M., L. A. V. Catao, and A. Timmermann, 2011, "Common factors in Latin America's business cycles," Journal of Development Economics, Vol. 95, No. 2, pp. 212-28.

Akin, C. and M. A. Kose, 2008, "Changing Nature of North-South Linkages: Stylized Facts and Explanations," Journal of Asian Economics, Vol. 19, pp. 1-28.

Allegret, J. P., and E. Essaadi, 2011, "Business cycles synchronization in East Asian economy:

Evidences from time-varying coherence study," Economic Modeling, Vol. 28, pp.351-65.

Allegret, J.-P., and A. Sand-Zantman, 2009, "Does a Monetary Union Protect against External Shocks? An Assessment of Latin American Integration," Journal of Policy Modeling, Vol. 31, No. 1, pp.102-18.

Ando, M., 2006, "Fragmentation and vertical intra-industry trade in East Asia," North American Journal of Economics and Finance, Vol. 17, No. 3, 2006, pp. 257-81.

Andrews, D., 1993, "Tests for Parameter Instability and Structural Change with Unknown Change Point," Econometrica, Vol. 61, pp. 821-56.

Arribas, I., F. Perez, and E. Tortosa-Ausina, 2011, "Trade Integration in the European Union; relative contributions of openness and interconnectedness," paper presented at the CESifo Economic Studies Conference on Measuring Economic Integration (Munich, 2011).

Artis, M., 2003, "Is there a European Business Cycle?," CESifo Working Paper Series 1053, CESifo Group Munich.

Artis, M., D. Christian, and K. Kholodilin, 2011a, "What drives regional business cycles? The role of common and spatial components," The Manchester School, Vol. 79, No. 5, pp. $1035-44$.

Artis, M., G.Choululiarakis, and P.K.G. Halischandra, 2011b, "Business Cycle Synchronization since 1880," The Manchester School, Vol. 79, No. 2, pp.173-207.

Artis, M. and H. Siebert, 2004, "Is There a European Business Cycle?," Macroeconomic policies in the world economy, Heidelberg and New York: Springer, pp.53-79.

Artis, M. J., H.-M. Krolzig, and J. Toro, 2004, “The European Business Cycle,” Oxford Economic Papers, Vol. 56:1, pp. 1-44.

Artis, M., M. Marcellino, and T. Proietti, 2004, "Dating Business Cycles: A Methodological Contribution with an Application to the Euro Area," Oxford Bulletin of Economics \& Statistics, Vol. 66, No. 4, pp. 537-65.

Artis, M. J. and W. Zhang, 1997, "International Business Cycles and the ERM: Is There a European Business Cycle?" International Journal of Finance and Economics, Vol. 2, No. 1, pp. 1-16.

Artis, M. J. and W. Zhang, 1999, "Further Evidence on the International Business Cycle and the ERM: Is There a European Business Cycle?” Oxford Economic Papers, Vol. 51, No. 1, pp.120-132.

Asian Development Bank, 2007, "Uncoupling Asia: Myth and Reality," In Asian Development Outlook 2007, pp.66-81, Philippines: Asian Development Bank.

Athukorala, P., and N. Yamashita, 2006, "Production fragmentation and trade integration: East Asia in a global context," North American Journal of Economics and Finance, Vol. 17, No.3, pp. 233-56. 
Babetskii, I., 2005, "Trade integration and synchronization of shocks," The Economics of Transition, The European Bank for Reconstruction and Development, Vol. 13, No. 1, pp. $105-38$.

Bacha, O. I., 2008, “A Common Currency Area for ASEAN? Issues and Feasibility,” Applied Economics, Vol. 40, No. 4, pp. 515-29.

Backus D. K., P. J. Kehoe and F. E. Kydland, 1995, "International Business Cycles: Theory and Evidence," in Thomas F. Cooley (ed.), Frontiers of Business Cycle Research, Princeton: Princeton University Press, pp. 331-57.

Balcilara, M. and D. Danjub, 2010, "Sources of Output Volatility in MENA Countries," Middle East Review (forthcoming).

Bayoumi, T., and B. Eichengreen, 1997, "Is Regionalism Simply a Diversion? Evidence from the Evolution of the EC and EFTA," NBER Chapters, in: Regionalism versus Multilateral Trade Arrangements, NBER-EASE Vol. 6, pp. 141-68. , 1994, "Macroeconomic Adjustment under Bretton Woods and the Post-Bretton-Woods Float: An Impulse-Response Analysis," Economic Journal, Vol. 104(425), pp. 813-27. , 1993, "Shocking Aspects of European Monetary Integration," Adjustment and growth in the European Monetary Union, Oxford; New York and Melbourne: Cambridge University Press, pp.193-229. , 1999, "Is Asia an Optimum Currency Area? Can It Become One? Regional, Global, and Historical Perspectives on Asian Monetary Relations," in Stefan C., Y. C. Park, J. Pisani-Ferry (eds.) Exchange Rate Policies in Emerging Asian Countries, Studies in the Growth Economies of Asia, Vol. 13, London and New York: Routledge, pp. 347-66.

Bayoumi, T., B. Eichengreen, and P. Mauro, 2000, “On Regional Monetary Arrangements for ASEAN," Journal of the Japanese and International Economies, Vol. 14(2), pp. 121-48.

Bejan, M., 2011, "Trade Agreements and International Comovements: the Case of NAFTA (North American Free Trade Agreement)," Review of Economic Dynamics, Vol. 14, No. 4, pp. 667-85.

Belke, A. and J. M. Heine, 2006, "Specialisation Patterns and the Synchronicity of Regional Employment Cycles in Europe," International Economics and Economic Policy, Vol. 3, No. 2, pp. 91-104. , 2007, "On the Endogeneity of an Exogenous OCA-Criterion: Specialisation and the Correlation of Regional Business Cycles in Europe," Empirica, Vol. 34, No. 1, pp.1544.

Bergman, M., M. D. Bordo, and L. Jonung, 1998, "Historical Evidence on Business Cycles: The International Experience," in, J.C. Fuhrer and S. Schuh, eds., Beyond Shocks: What Causes Business Cycles?, Federal Reserve Bank of Boston, Conference Series No. 42.

Blanchard, O., H. Faruqee, and M. Das, 2010, "The Initial Impact of the Crisis on Emerging Market Countries," Brookings Papers on Economic Activity, Vol. 41(Spring), pp. 263323.

Blanchard, O., and J. Simon, 2001, "The Long and Large Decline in U.S., Output Volatility," Brookings Papers on Economic Activity, pp. 135-74.

Bordo, M. D., and T. Helbling, 2011, "International Business Cycle Synchronization In Historical Perspective," The Manchester School, Vol. 79, Issue 2, pp. 208-38.

Böwer, U., and C. Guillemineau, 2006, "Determinants of Business Cycle Synchronisation across Euro-zone Countries,” ECB Working Paper No 587. 
Burns, A. F., and W. C. Mitchell, 1946, Measuring Business Cycles. Cambridge, Massachusetts: National Bureau of Economic Research.

Calderon, C. A., A. E. Chong, and E. H. Stein, 2007, “Trade Intensity and Business Cycle Synchronization: Are Developing Countries any Different?" Journal of International Economics, Vol. 71, pp.2-21.

Caldéron, C., 2003, "Do Free Trade Agreements Enhance the Transmission of Shocks Across Countries?" Working Paper No. 213 (Central Bank of Chile).

Camacho, M., G. Perez-Quiros, and L. Saiz, 2008, "Do European Business Cycles Look Like One?" Journal of Economic Dynamics and Control, Vol. 32, No. 7, pp. 2165-90. , 2006, “Are European Business Cycles Close Enough to Be Just One?” Journal of Economic Dynamics and Control, Vol. 30(9-10): pp. 1687-1706.

Canova, F., and M. Ciccarelli, 2012, "ClubMed? Cyclical fluctuations in the Mediterranean basin," Working Paper, University of Pampeu Fabra.

Canova, F., and A. Schlaepfer, 2011, "Mediterranean business cycles: structure and characteristics," Economics Working Papers 1267, Department of Economics and Business, Universitat Pompeu Fabra.

Canova, F., M. Ciccarelli, and E. Ortega, 2007, "Similarities and Convergence in G-7 Cycles," Journal of Monetary Economics, Vol. 54, pp. 850-78.

Cerro, A., Pineda, J., 2002, "Latin American Growth Cycles: Empirical Evidence 1960-2000," Estudios de Economía, Vol. 29.

Chen, S.-W. and C.H. Shen, 2007, "A sneeze in the U.S., a cough in Japan, but pneumonia in Taiwan? An application of the Markov-switching vector autoregressive model," Economic Modelling, Vol. 24, pp.1-14.

Cheung, Y.W., and J. Yuen, 2004, “An Output Perspective on a Northeast Asia Currency Union," CESifo Working Paper Series 1250, CESifo Group Munich.

Chiquiar, D. and M. Ramos-Francia, 2005, "Trade and Business-Cycle Synchronization: Evidence from Mexican and U.S. Manufacturing Industries," North American Journal of Economics and Finance, Vol. 16, No. 2, pp. 187-216.

Choe, J.-I., 2001, “An Impact of Economic Integration through Trade: On Business Cycles for 10 East Asian Countries," Journal of Asian Economics, Vol. 12, No. 4, pp. 569-86.

Chow, H. K., and Y. Kim, 2003, "A common currency peg in East Asia? Perspectives from Western Europe," Journal of Macroeconomics, Vol. 25, No. 3, pp. 331-50.

Claessens, S., and K. Forbes, 2001, International Financial Contagion, Boston: Kluwer Academic Press.

Clark, D. P., 2002, "Intra-Industry Specialization and the North American Free Trade Agreement," International Trade Journal, Vol.16, No.4, pp. 393-411.

Clark, T. E. and E. van Wincoop, 2001, "Borders and Business Cycles," Journal of International Economics, Vol. 55, No. 1, pp. 59-85.

Cortinhas, C., 2007, "Intra-industry trade and business cycles in ASEAN," Applied Economics, Vol. 39, No. 7, pp. 893-902.

Crosby, M. 2003, "Business cycle correlations in Asia-Pacific," Economics Letters, Vol. 80, No. 1, pp. 35-44.

Crucini, M., M. A. Kose, and C. Otrok, 2011, "What are the driving forces of international business cycles?," Review of Economic Dynamics Vol. 14, No. 1, pp. 156-75.

Cuevas, A., M. Messmacher, and A. Werner, 2002, "Macroeconomic Synchronization between Mexico and its NAFTA Partners," Working Paper, Bank of Mexico. 
Davis, S., 2011, "Financial Integration and International Business Cycle Comovement: The role of Balance Sheets," Working Paper, No. 89, Federal Reserve Board of Dallas.

De Backer, K., and N. Yamano, 2007, “The Measurement of Globalization using International Input-Output Tables," OCED Science, Technology, and Industry Working Papers, No.1815-1965.

De Haan, J., R. Inklaar, R. Jong-a-Pin, 2008, "Will Business Cycles in the Euro Area Converge? A Critical Survey of Empirical Research," Journal of Economic Surveys, Vol. 22, No. 2: pp. 234-73.

Devereux, M., P.R. Lane, C. Y. Park, S. J. Wei, 2011, The Dynamics of Asian Financial Integration: Facts and Analytics, Routledge Studies in Modern World Economy.

Di Giovanni, J., and A. A. Levchenko, 2010, "Putting the Parts Together: Trade, Vertical Linkages, and Business Cycle Comovement," American Economic Journal: Macroeconomics, American Economic Association, Vol. 2, No. 2, pp. 95-124.

Di Mauro, F., S. Dees, and W. J. Mc Kibbon, 2008, Globalization, Regionalism, and Economic Interdependence, Cambridge University Press.

Doyle, B., and J. Faust, 2005, "Breaks in the Variability and Comovement of G-7 Economic Growth," Review of Economics and Statistics, Vol. 87, No. 4, pp. 721-40.

Doz, C., D. Giannone, and L. Reichlin, 2008, “A Quasi Maximum Likelihood Approach for Large Approximate Dynamic Factor Models,” ECARES Working Papers No. 2008_034.

Fidrmuc, J. and I. Korhonen, 2010, "The impact of the global financial crisis on business cycles in Asian emerging economies," Journal of Asian Economics, Vol. 21, No. 3, pp. 293303.

Fiess, N., 2007, "Business Cycle Synchronization and Regional Integration: A Case Study for Central America," World Bank Economic Review, Vol. 21, No. 1, pp. 49-72.

Forni, M., M. Hallin, M. Lippi, and L. Reichlin, 2000, "The Generalized Dynamic-Factor Model: Identification and Estimation," Review of Economics and Statistics, Vol. 82, No. 4, pp. 540-54.

Forni, M., and L. Reichlin, 2001, "Federal policies and local economies: Europe and the US," European Economic Review, Vol. 45, Issue 1, pp. 109-34.

Francis, N., M.T. Owyang, O. Savascin, 2012, "An endogenously clustered factor approach to international business cycles,” Working Papers 2012-014, Federal Reserve Bank of St. Louis.

Frankel, J., and A. K. Rose, 1998, "The Endogeneity of the Optimum Currency Area Criteria," Economic Journal, Royal Economic Society, Vol. 108(449), pp. 1009-25.

Fullerton, T. M., Jr., W. C. Sawyer, and R. L. Sprinkle, 2011, "Intra-Industry Trade in Latin America and the Caribbean," International Trade Journal, Vol. 25, No.1, pp.74-111.

Genberg, H. and P. L. Siklos, 2010, "Revisiting the Shocking Aspects of Asian Monetary Unification," Journal of Asian Economics, Vol. 21, No. 5, pp. 445-55.

Giannone, D., and L. Reichlin, 2006, "Trends and cycles in the euro area: how much heterogeneity and should we worry about it?” Working Paper Series 595, European Central Bank.

Giannone, D., M. Lenza, and L. Reichlin, 2010, "Business Cycles in the Euro Area," in A. Alesina and F. Giavazzi, eds., Europe and the Euro, University of Chicago Press, pp. 14 $-67$.

Girardin, E., 2004, "Regime-Dependent Synchronization of Growth Cycles between Japan and East Asia," Asian Economic Papers, Vol. 3, No. 3, pp. 147-76. 
, 2005, "Growth-Cycle Features of East Asian Countries: Are They Similar?" International Journal of Finance and Economics, Vol. 10, No. 2, pp.143-56.

Goncalves, E.S., M. Rodrigues, T. Soares, 2009. "Correlation of Business Cycles in the Euro Zone," Economics Letters, Vol. 102, No. 1, pp. 56-58.

Gonuguntla, S., 2011, "An Evaluation of the New Zealand-Singapore Closer Economic Partnership Agreement," International Review of Business Research Papers, Vol. 7, pp. 119-27.

Guha, D. and A. Banerji, 1998, "Testing for regional cycles: a Markov-switching approach," Journal of Economic \& Social Measurement, Vol. 25, No. 3/4, pp. 163-82.

Hakura, D.S., 2009, "Output Volatility in Emerging Market and Developing Countries: What Explains the 'Great Moderation' of 1970-2003?" Czech Journal of Economics and Finance, 2009. Vol. 59, No. 3: pp. 229-54.

Hakura, D. S., 2007, "Output Volatility and Large Output Drops in Emerging Market and Developing Countries," IMF Working Papers 07/114, International Monetary Fund.

Hall, V. B., K. Kim, and R.A. Buckle, 1998, "Pacific Rim Business Cycle Analysis: Synchronization and Volatility," New Zealand Economic Papers, Vol. 32.

Hall, V. B., and C. J. McDermott, 2011, "An unobserved components common cycle for Australasia? Implications for a common currency," Working Paper.

He, D. and W. Liao, 2010, “Asian Business Cycle Synchronisation," A paper presented in RBA "China and East Asia in the Global Economy."

He, D., L. Cheung, and J. Chang, 2007, "Sense and Nonsense on Asia's Export Dependency and the Decoupling Thesis," Working Papers 0703, Hong Kong Monetary Authority.

Head, A., 2002, "Aggregate Fluctuations with National and International Returns to Scale," International Economic Review, Vol. 43, pp. 1101-25.

Heathcote, J., and F. Perri, 2002, "Financial Autarky and International Business Cycles," Journal of Monetary Economics, Vol. 49, pp. 601-28. , 2004, "Financial Globalization and Real Regionalization," Journal of Economic Theory, Vol. 119:1, pp. 207-43.

Hegerty, S. W., 2010, “Central European Business Cycles," Eastern European Economics, Vol. 48, No. 2, pp. 56-73.

Helbling, T., P. Berezin, M. A. Kose, M. Kumhof, D. Laxton, and N. Spatafora, 2007. "Decoupling the Train? Spillovers and Cycles in the Global Economy." In World Economic Outlook, April, pp. 121-60. Washington: International Monetary Fund.

Herrera Hernandez, J., 2004, "Business Cycles in Mexico and the United States: Do They Share Common Movements?," Journal of Applied Economics, Vol. 7, No. 2, pp.303-23.

Hirata, H., S. H. Kim, and M. A. Kose, 2007, "Sources of Fluctuations: The Case of MENA," Emerging Markets Finance and Trade, Vol. 43, No. 1, pp. 5-34. , 2004, "Integration and Fluctuations: The Case of MENA," Emerging Markets Finance and Trade, Vol. 40, No. 6, pp. 48-67.

Hoffmaister, A. W., M. Pradhan, and H. Samiei, 1998, "Have North-South growth linkages changed?," World Development, Vol. 26, No. 5, pp. 791-808.

Huang, Y. and F. Guo, 2006 "Is currency union a feasible option in East Asia?: A multivariate structural VAR approach," Research in International Business and Finance, Vol. 20, Issue 1, pp. 77-94.

Hummels, D., J. Ishii, and K.-M. Yi, 2001, "The Nature and Growth of Vertical Specialization in World Trade," Journal of International Economics, Vol.54, No. 1, pp. 75-96. 
Imbs, J., 2004, “Trade, Finance, Specialization and Synchronization," Review of Economics and Statistics, Vol. 86, pp. 723-34.

, 2011, "What Happened to the East Asian Business Cycle," Devereux M., P. Lane, C-Y. Park, S-J. Wei (eds.), The Dynamics of Asian Financial Integration: Facts and Analytics, London and New York: Routledge, pp. 284-310.

Jansen, W.J., and A.C.J. Stokman, 2004, "Foreign Direct Investment and International Business Cycle Comovement," Working Paper Series, No.401, European Central Bank.

Jacobo, A. D., 2002, "Taking the Business Cycle's Pulse to Some Latin American Economies: Is There a Rhythmical Beat?" Estudios Economicos, Vol. 17, No. 2, pp. 219-45.

Kalemli-Ozcan, S., E. Papaioannou and J. L. Peydro, 2011, "Financial Regulation, Financial Globalization and the Synchronization of Economic Activity," Working paper, University of Houston.

Kalemli-Ozcan, S., B. E. Sørensen, and O. Yosha, 2001, "Risk Sharing and Industrial Specialization: Regional and International Evidence," American Economic Review, Vol. 93, No. 3, pp. 903-18.

Kumakura, M., 2006, "Trade and business cycle correlations in Asia-Pacific," Journal of Asian Economics, Vol. 17, pp. 622-45.

Karagedikli, O., and L.A. Thorsrud, 2012, "Global and Regional Business Cycles: Shocks and Propagations," Reserve Bank of New Zealand.

Keida, M., 2009, "Linkage of Business Cycles in East Asian Countries after the Currency Crisis," Public Policy Review, Vol. 5, No. 1, pp. 89-108.

Kim, S., J.-W. Lee, and C.Y. Park, 2011, “Emerging Asia: Decoupling or Recoupling," World Economy, Vol. 34, No. 1, pp. 23-53.

Kim, S., S. H. Kim and Y. Wang, 2006, "Financial Integration and Consumption Risk Sharing in East Asia," Japan and the World Economy, Vol. 18, No. 2, pp. 143-57.

Kim, H., S. Kim, and Y. Wang, 2005, "International Capital Flows and Boom-Bust Cycles in the Asia Pacific Region," Discussion Papers Series, Department of Economics, Tufts University 0506, Department of Economics, Tufts University.

Koopman, S. J. and J. V. E. Azevedo, 2008, "Measuring Synchronization and Convergence of Business Cycles for the Euro area, UK and US," Oxford Bulletin of Economics \& Statistics, Vol. 70, No. 1, pp. 23-51.

Kose, M. A., C. Otrok, and E. S. Prasad, 2012, "Global Business Cycles: Convergence or Decoupling?” International Economic Review, Vol. 87, pp. 178-90.

Kose, M. A., and E. S. Prasad, 2010, Emerging Markets: Resilience and Growth Amid Global Turmoil, Washington, DC: Brookings Institution Press.

Kose, M. A., E. S. Prasad, and M. E. Terrones, 2009, "Does openness to international financial flows raise productivity growth?" Journal of International Money and Finance, Elsevier, Vol. 28, No. 4, pp. 554-80.

— 2003, "How Does Globalization Affect the Synchronization of Business Cycles?" American Economic Review, Papers and Proceedings, Vol. 93, pp. 57-62.

Kose, M. A., C. Otrok, and C. Whiteman, 2008, "Understanding the Evolution of World Business Cycles," Journal of International Economics, Vol. 75, No. 1, pp. 110-30.

_ 2003, "International Business Cycles: World, Region, and Country Specific Factors," American Economic Review, Vol. 93, pp. 1216-39. 
Kose, M. A. and K. Yi, 2006, "Can the Standard International Business Cycle Model Explain the Relation between Trade and Comovement?” Journal of International Economics, Vol. 68, pp. 267-95.

Kose, M. A., G. M. Meredith, and C. M. Towe, 2005, "How Has NAFTA Affected the Mexican Economy? Review and Evidence," Monetary Policy and Macroeconomic Stabilization in Latin America, Berlin and New York: Springer, pp. 35-81.

Kose, M. A., and A. Rebucci, 2005, "How might CAFTA Change Macroeconomic Fluctuations in Central America? Lessons from NAFTA," Journal of Asian Economics, Vol. 16, No. 1, pp. 77-104.

Kose, M. A., P. Loungani, and M. E. Terrones, 2013, “Global Recessions and Global Recoveries," IMF Working Paper, forthcoming.

Kouparitsas, M. A., 2001, "Is the United States an optimum currency area? an empirical analysis of regional business cycles," Working Paper Series, No. 01-22, Federal Reserve Bank of Chicago.

Kouparitsas, M. A. 1999, "Is the EMU a viable common currency area? A VAR analysis of regional business cycles," Economic Perspectives, Vol. 23, No. 4: 2.

Krugman, P., 1993, "Lessons of Massachusetts for EMU," In Adjustment and Growth in the European Monetary Union, edited by Francisco Torres and Francesco Giavazzi, pp. 24161. Cambridge University Press.

Kumakura, M., 2006, "Trade and Business Cycle Co-movements in Asia-Pacific," Journal of Asian Economics, Vol. 17, No. 4, pp. 622-45.

Lane, P. R, and G. M. Milesi-Ferretti, 2011, "The Cross-Country Incidence of the Global Crisis," IMF Economic Review, Vol. 59, No. 1, pp. 77-111.

, "The External Wealth of Nations Mark II: Revised and Extended Estimates of Foreign Assets and Liabilities: 1970-2004,"Journal of International Economics, Vol. 73, No. 2, pp. $223-50$.

Larsson, A., N. Gaco, and H. Sikstrom, 2011, "The Behaviour of Aggregate and Regional Business Cycles in the Nordic Countries," Stockholm University, Working Paper.

Lee, J., 2012, "Measuring Business Cycle Comovements in Europe: Evidence from a Dynamic Factor Model with Time-varying Parameters," Economics Letters, Vol. 115, No. 3, pp. 438-40.

Lee, G. H. Y., 2011, “Aggregate Shocks Decomposition For Eight East Asian Countries," Journal of the Asia Pacific Economy, Vol. 16, pp. 215-32.

Lee C., and M. Azali, 2012, "Testing the validity of the monetary model for ASEAN with structural break," Applied Economics, Vol. 44, No. 25, pp. 3229-236.

Lee, G. H. Y. , and M. Azali, 2010, "The endogeneity of the Optimum Currency Area criteria in East Asia," Economic Modelling, Vol. 27, pp. 165-70.

Lee, G. H. Y. and G. M. Koh, 2012, "The Prospects of a Monetary Union in East Asia," Economic Modelling, Vol. 29, Issue 2, pp. 96-102.

Lee, J-W., Y. C. Park, and K. Shin, 2003, “A Currency Union in East Asia.” ISER Discussion Paper No. 571.

Lee, Y-F. L., 2007, "Bilateral Trade and Intra-regional Business Cycles: Is East Asia Feasible for a Currency Area?" Global Economy Journal, Vol. 7, Issue No. 3.

Lederman, D., W.F. Maloney, and L. Servén. 2005, Lessons from NAFTA for Latin America and the Caribbean, Stanford University Press and World Bank, Latin American Development Forum Series: Palo Alto, California and Washington, DC. 
Loayza, N., H. Lopez, and A. Ubide, 2001, "Comovements and Sectoral Interdependence: Evidence for Latin America, East Asia, and Europe," IMF Staff Papers, Vol. 48, No. 2, pp. 7.

Lumsdaine, R. L., and E. S. Prasad, 2003, "Identifying the Common Component in International Economic Fluctuations," Economic Journal, Vol. 113, pp. 101-27.

Male, R., 2011, "Developing Country Business Cycles: Characterizing the Cycle," Emerging Markets Finance and Trade, Vol. 47, pp. 20-39.

Massmann, M., and J. Mitchell, 2004, "Reconsidering the evidence: Are Euro Area business cycles converging?," Journal of Business Cycle Measurement and Analysis, Vol. 2004, No. 3, pp. 275-307.

Mehrara, M. and K.N. Oskoui, 2007, "The Sources of Macroeconomic Fluctuations in Oil Exporting Countries: A Comparative Study,” Economic Modelling, Vol. 24, No. 3, pp. 365-79.

Milesi-Ferretti, G.M., F. Strobbe, and N. T. Tamirisa, 2010, "Bilateral Financial Linkages and Global Imbalances: A view on the eve of the financial crisis," IMF Working Paper, No. $10 / 257$.

Moneta, F. and R. Ruffer, 2009, "Business Cycle Synchronisation in East Asia," Journal of Asian Economics, Vol. 20, No. 1, pp. 1-12.

Montoya, L. A. and J. de Haan, 2008, "Regional Business Cycle Synchronization in Europe?" International Economics and Economic Policy, Vol. 5, No. 1-2, pp. 123-37.

Mumtaz, H., S. Simonelli and P. Surico, 2011, "International Comovements, Business Cycles and Inflation: An Historical Perspective," Review of Economics Dynamics, Vol. 14, pp. 176-98.

Neaime, S., 2005, "Financial Market Integration and Macroeconomic Volatility in the MENA Region: An Empirical Investigation," Review of Middle East Economics and Finance, Vol. 3, No. 3: pp. 231-55.

Ng, E. C. Y., 2010, "Product fragmentation and business-cycle comovement," Journal of International Economics, Vol. 82, pp.1-14.

Otrok, C. and C. Whiteman, 1998, "Bayesian Leading Indicators: Measuring and Predicting Economic Conditions in Iowa," International Economic Review, Vol. 39, No. 4, pp. 997 1014.

Park, Y. C. and K. Shin, 2009, "Economic Integration and Changes in the Business Cycle in East Asia: Is the Region Decoupling from the Rest of the World?," Asian Economic Papers, Vol. 8, No. 1, pp. 107-40.

Petri, P. A., M. G. Plummer, and F. Zhai, 2011, "The Trans-Pacific Partnership and Asia-Pacific Integration: A Quantitative Assessment," East-West Center Working Papers, No. 119.

Phillips, K. R., and J. Canas, 2008, "Regional business cycle integration along the US Mexico border," Annals of Regional Science, Vol. 42, No. 1, pp.153-68.

Plummer, M. G., 2006, "Toward Win-Win Regionalism in Asia: Issues and Challenges in Forming Efficient Trade Agreements,” ADB Working Paper Series on Regional Economic Integration, No. 5.

Rana, P. B., 2008, "Trade Intensity and Business Cycle Synchronization: The Case of East Asian Countries," Singapore Economic Review, Vol. 53, No. 2, pp. 279-92.

Rana, P. B., 2007, "Economic Integration and Synchronization of Business Cycles in East Asia," Journal of Asian Economics, Vol. 18, No. 5, pp.711-25. 
Ravn, M. O., and E. Mazzenga, 2004, "International business cycles: the quantitative role of transportation costs," Journal of International Money and Finance, Vol. 23, No. 4, pp. 645-71.

Rodriguez-Pose, A. and U. G. O. Fratesi, 2007, "Regional Business Cycles and the Emergence of Sheltered Economies in the Southern Periphery of Europe," Growth \& Change, Vol. 38, No. 4, pp. 621-48.

Rose, A.K., and M. Spiegel, 2011, "Cross-country causes and the consequences of the crises: An Update," European Economic Review, Vol. 55, pp. 209-324.

Sargent, T. J, 1989, "Two Models of Measurements and the Investment Accelerator," Journal of Political Economy, Vol. 97, No. 2, pp. 251-87.

Sargent, T. J., and Christopher A. Sims, 1977, "Business Cycle Modeling Without Pretending to Have Too Much A Priori Economic Theory," in Christopher A. Sims et al., New Methods in Business Cycle Research, Minneapolis: Federal Reserve Bank of Minneapolis.

Sato, K., and Z. Zhang, 2006, "Real Output Co-movements in East Asia: Any Evidence for a Monetary Union?” World Economy, Vol. 29, No. 12, pp.1671-89.

Sato, K., Z. Zhang, and M. McAleer, 2011, "Identifying Shocks in Regionally Integrated East Asian Economies with Structural VAR and Block Exogeneity," Mathematics and Computers in Simulation, Vol. 81, Issue 7, pp. 1353-64.

_ 2004, "Is a monetary union feasible for East Asia?" Applied Economics, Vol. 36, No. 10, pp. 1031-43.

Selover, D.D., 2004, "International co-movements and business cycle transmission between Korea and Japan," Journal of the Japanese and International Economies, Vol. 18, pp.5783. , 1999, "International interdependence and business cycle transmission in ASEAN," Journal of the Japanese and International Economies, Vol. 13, pp. 230-53.

Seymen, A., 2012. "Euro area business cycles," Journal of Business Cycle Measurement and Analysis, Vol. 2012, No. 1, pp. 1-31.

Shin, K., and C. H. Sohn, 2006, "Trade and Financial Integration in East Asia: Effects on Comovements," World Economy, Vol. 29, No. 12, pp. 1649-69.

Shin, K. and Y. Wang, 2005, "The Impact of Trade Integration on Business Cycle Comovements in Europe," Review of World Economics/Weltwirtschaftliches Archiv, Vol. 141, No. 1, pp. 104-23. , 2004, "Trade Integration and Business Cycle Co-movements: The Case of Korea with Other Asian Countries," Japan and the World Economy, Vol. 16, No. 2, pp. 213-30.

— 2003, "Trade Integration and Business Cycle Synchronization in East Asia," Asian Economic Papers, Vol. 2, No. 3, pp. 1-20.

Siedschlag, J., and G. Tondl, 2011, "Regional output growth synchronisation with the Euro Area," Empirica, Vol. 38, No. 2, pp. 203-21.

Smith, H., G. Day, B. Thomas, and L. Yeaman, 2005, "The changing pattern of East Asia's growth," Economic Round-up, Vol. Summer 2005, pp. 45-67.

Sorensen, B. E., Y.-T. Wu, and Y. Zhu, 2007, "Home Bias and International Risk Sharing: Twin Puzzles Separated at Birth," Journal of International Money and Finance, Vol. 26, No. 4, pp. 587-605.

Sosa, S., 2008, "External Shocks and Business Cycle Fluctuations in Mexico: How Important are U.S. Factors?” International Monetary Fund, IMF Working Papers: 08/100: 31 pages. 
Stock, J. H., and M. W. Watson, 2009, "Forecasting in Dynamic Factor Models Subject to Structural Instability," in Jennifer Castle and Neil Shephard (eds.), The Methodology and Practice of Econometrics, Oxford: Oxford University Press.

- 2005, "Understanding Changes in International Business Cycles." Journal of the European Economic Association, Vol. 3, No. 5, pp. 968-1006.

_ 2003,"Understanding Changes in International Business Cycles," NBER Working Paper No: 9859.

- 2002, "Macroeconomic Forecasting Using Diffusion Indexes," Journal of Business and Economic Statistics, Vol. 20, No. 2, pp. 147-62.

— 1989, "New Indexes of Coincident and Leading Economic Indicators," in Olivier J. Blanchard and Stanley Fischer (eds.), NBER Macroeconomics Annual 1989, Vol. 4, Cambridge: The MIT Press, pp. 351-409.

Sussmuth, B., and U. Woitek, 2004, "Business Cycles and Comovement in Mediterranean Economics: A National and Areawide Perspective," Emerging Markets Finance and Trade, Vol. 40, No. 6, pp. 7-28.

Swiston, A. and T. Bayoumi, 2008, "Spillovers Across NAFTA," International Monetary Fund, IMF Working Papers: 08/3.

Tapsoba, S. J.-A., 2010, “Trade Intensity and Business Cycle Synchronicity in Africa," African Development Review, Vol. 22, No. 1, pp. 149-72.

Thorsrud, L. A., 2012, "Global and Regional Business Cycles. Shocks and propagations," Mimeo.

Torres, A. and O. Vela, 2003, "Trade Integration and Synchronization between the Business Cycles of Mexico and the United States," North American Journal of Economics and Finance, Vol. 14, No. 3, pp. 319-42.

Waysand, C., K. Ross, and J. de Guzman, 2010, "European Financial Linkages: A New Look at Imbalances," IMF Working Paper, No. 10/295.

Weber, E., 2012, "Regional and outward economic integration in South-East Asia," Applied Economics, Vol. 44, No. 10, pp. 1271-83.

- 2009, "Common and uncommon sources of growth in Asia Pacific," Journal of the Japanese and International Economies, Vol. 23, No. 1, pp.20-36.

Weyerstrass, K., B. van Aarle, M. Kappler, and A. Seymen, 2012, "Business Cycle Synchronisation with(in) the Euro Area: In Search of a 'Euro Effect'," Open Economies Review, Vol. 22, No. 3, pp. 427-46.

Yi, K.-M., 2003, “Can Vertical Specialization Explain the Growth of World Trade?” Journal of Political Economy, Vol.111, pp. 52-102.

Zarnowitz, V., 1992, Business cycles: theory, history, indicators, and forecasting, The University of Chicago Press. 
Table 1. Variance Decompositions (1960-2010)

\begin{tabular}{|c|c|c|c|c|c|}
\hline \multirow[b]{2}{*}{ Variables / Regions } & \multicolumn{5}{|c|}{ Factors } \\
\hline & Global & Regional & $\begin{array}{l}\text { Global + } \\
\text { Regional }\end{array}$ & Country & Idiosyncratic \\
\hline \multicolumn{6}{|l|}{ Output } \\
\hline World & 10.40 & 12.86 & 23.26 & 40.79 & 34.46 \\
\hline North America & 16.64 & 33.59 & 50.23 & 36.79 & 12.42 \\
\hline Europe & 26.85 & 21.62 & 48.46 & 33.07 & 18.08 \\
\hline Ocenia & 7.45 & 3.60 & 11.04 & 60.49 & 25.90 \\
\hline Asia & 8.92 & 21.36 & 30.28 & 46.74 & 22.32 \\
\hline Latin America and the Caribbean & 8.00 & 17.42 & 25.42 & 36.85 & 36.95 \\
\hline Sub-Saharan Africa & 4.58 & 2.52 & 7.10 & 41.40 & 48.95 \\
\hline Middle East and North Africa & 5.99 & 5.95 & 11.94 & 52.58 & 32.61 \\
\hline \multicolumn{6}{|l|}{ Consumption } \\
\hline World & 8.52 & 7.44 & 15.96 & 34.27 & 48.43 \\
\hline North America & 17.87 & 27.41 & 45.29 & 35.85 & 17.83 \\
\hline Europe & 26.31 & 7.23 & 33.54 & 31.39 & 34.41 \\
\hline Ocenia & 4.53 & 6.11 & 10.64 & 35.29 & 50.22 \\
\hline Asia & 8.12 & 11.89 & 20.01 & 31.85 & 47.51 \\
\hline Latin America and the Caribbean & 4.72 & 11.00 & 15.72 & 34.98 & 48.61 \\
\hline Sub-Saharan Africa & 2.81 & 2.83 & 5.64 & 35.31 & 57.06 \\
\hline Middle East and North Africa & 1.30 & 4.04 & 5.35 & 38.12 & 54.07 \\
\hline \multicolumn{6}{|l|}{ Investment } \\
\hline World & 4.95 & 11.00 & 15.95 & 27.06 & 55.73 \\
\hline North America & 5.47 & 34.58 & 40.05 & 44.81 & 13.80 \\
\hline Europe & 12.72 & 22.73 & 35.45 & 34.98 & 29.18 \\
\hline Ocenia & 0.18 & 8.23 & 8.40 & 64.88 & 23.81 \\
\hline Asia & 5.35 & 10.91 & 16.27 & 35.05 & 48.19 \\
\hline Latin America and the Caribbean & 3.16 & 14.48 & 17.64 & 28.59 & 52.99 \\
\hline Sub-Saharan Africa & 2.90 & 1.96 & 4.86 & 14.40 & 78.89 \\
\hline Middle East and North Africa & 1.15 & 7.37 & 8.52 & 31.47 & 57.05 \\
\hline
\end{tabular}

Notes: The model is estimated over the full sample period (1960-2010) and the variance decompositions are computed for each country, for output, consumption and investment. The cross-sectional mean of the variance share (in percent) attributable to the relevant factor is reported in each cell. The cross-sectional means are calculated for the world and relevant region indicated in the first column. The column marked "Global+Regional" denotes the sums of the average variance shares of the global and regional factors. 
Table 2. Variance Decompositions (1960-84)

\begin{tabular}{|c|c|c|c|c|c|}
\hline \multirow[b]{2}{*}{ Variables / Regions } & \multicolumn{5}{|c|}{ Factors } \\
\hline & Global & Regional & $\begin{array}{c}\text { Global + } \\
\text { Regional } \\
\end{array}$ & Country & Idiosyncratic \\
\hline \multicolumn{6}{|l|}{ Output } \\
\hline World & 13.40 & 10.68 & 24.08 & 41.00 & 32.56 \\
\hline North America & 22.46 & 24.28 & 46.74 & 39.02 & 12.62 \\
\hline Europe & 27.72 & 18.28 & 46.00 & 30.46 & 22.13 \\
\hline Ocenia & 11.82 & 4.37 & 16.19 & 52.93 & 27.30 \\
\hline Asia & 11.45 & 7.71 & 19.16 & 51.41 & 27.05 \\
\hline Latin America and the Caribbean & 14.53 & 16.41 & 30.94 & 37.55 & 29.81 \\
\hline Sub-Saharan Africa & 6.68 & 4.61 & 11.29 & 41.65 & 44.19 \\
\hline Middle East and North Africa & 8.05 & 6.99 & 15.04 & 50.78 & 30.22 \\
\hline \multicolumn{6}{|l|}{ Consumption } \\
\hline World & 10.57 & 8.24 & 18.81 & 36.95 & 41.78 \\
\hline North America & 27.69 & 16.10 & 43.79 & 38.99 & 15.40 \\
\hline Europe & 25.15 & 9.09 & 34.24 & 30.16 & 33.87 \\
\hline Ocenia & 4.92 & 5.29 & 10.21 & 34.45 & 50.31 \\
\hline Asia & 9.84 & 7.13 & 16.96 & 38.98 & 41.35 \\
\hline Latin America and the Caribbean & 10.23 & 11.18 & 21.41 & 35.96 & 41.00 \\
\hline Sub-Saharan Africa & 4.54 & 6.38 & 10.92 & 40.20 & 45.97 \\
\hline Middle East and North Africa & 1.21 & 6.58 & 7.79 & 36.77 & 51.92 \\
\hline \multicolumn{6}{|l|}{ Investment } \\
\hline World & 6.12 & 9.55 & 15.67 & 27.99 & 54.00 \\
\hline North America & 7.41 & 32.15 & 39.55 & 46.33 & 10.95 \\
\hline Europe & 11.55 & 18.18 & 29.73 & 35.64 & 32.98 \\
\hline Ocenia & 1.27 & 6.23 & 7.50 & 62.99 & 23.33 \\
\hline Asia & 6.23 & 7.60 & 13.82 & 34.12 & 49.42 \\
\hline Latin America and the Caribbean & 5.65 & 11.39 & 17.04 & 28.76 & 52.55 \\
\hline Sub-Saharan Africa & 4.58 & 3.16 & 7.73 & 16.06 & 73.86 \\
\hline Middle East and North Africa & 2.18 & 9.60 & 11.79 & 35.71 & 48.53 \\
\hline
\end{tabular}

Notes: The model is estimated over the 1960-84 period and the variance decompositions are computed for each country, for output, consumption and investment. The cross-sectional mean of the variance share (in percent) attributable to the relevant factor is reported in each cell. The cross-sectional means are calculated for the world and relevant region indicated in the first column. The column marked "Global+Regional" denotes the sums of the average variance shares of the global and regional factors. 
Table 3. Variance Decompositions (1985-2010)

\begin{tabular}{|c|c|c|c|c|c|}
\hline \multirow[b]{2}{*}{ Variables / Regions } & \multicolumn{5}{|c|}{ Factors } \\
\hline & Global & Regional & $\begin{array}{c}\text { Global + } \\
\text { Regional }\end{array}$ & Country & Idiosyncratic \\
\hline \multicolumn{6}{|l|}{ Output } \\
\hline World & 9.16 & 19.46 & 28.63 & 34.61 & 33.53 \\
\hline North America & 30.41 & 32.87 & 63.28 & 23.03 & 11.09 \\
\hline Europe & 19.85 & 40.25 & 60.10 & 19.69 & 19.06 \\
\hline Ocenia & 20.93 & 20.33 & 41.26 & 29.40 & 25.76 \\
\hline Asia & 5.08 & 32.49 & 37.56 & 33.88 & 26.14 \\
\hline Latin America and the Caribbean & 6.55 & 14.55 & 21.10 & 41.19 & 34.67 \\
\hline Sub-Saharan Africa & 5.70 & 7.64 & 13.34 & 36.56 & 45.82 \\
\hline Middle East and North Africa & 3.72 & 8.61 & 12.33 & 49.93 & 32.17 \\
\hline \multicolumn{6}{|l|}{ Consumption } \\
\hline World & 6.49 & 13.85 & 20.34 & 30.38 & 46.31 \\
\hline North America & 31.06 & 22.01 & 53.07 & 26.55 & 17.95 \\
\hline Europe & 14.16 & 29.50 & 43.66 & 18.74 & 35.55 \\
\hline Ocenia & 14.75 & 11.30 & 26.05 & 33.46 & 35.44 \\
\hline Asia & 2.21 & 24.18 & 26.39 & 27.84 & 43.74 \\
\hline Latin America and the Caribbean & 3.40 & 10.27 & 13.67 & 34.61 & 48.85 \\
\hline Sub-Saharan Africa & 4.49 & 4.38 & 8.86 & 33.28 & 54.56 \\
\hline Middle East and North Africa & 2.80 & 8.51 & 11.30 & 38.36 & 44.92 \\
\hline \multicolumn{6}{|l|}{ Investment } \\
\hline World & 8.58 & 15.72 & 24.30 & 29.12 & 43.79 \\
\hline North America & 24.96 & 30.17 & 55.12 & 33.77 & 9.77 \\
\hline Europe & 19.57 & 31.40 & 50.97 & 26.01 & 22.22 \\
\hline Ocenia & 16.36 & 29.21 & 45.57 & 34.59 & 16.02 \\
\hline Asia & 5.11 & 26.29 & 31.40 & 32.19 & 34.09 \\
\hline Latin America and the Caribbean & 5.89 & 12.12 & 18.01 & 37.06 & 42.25 \\
\hline Sub-Saharan Africa & 4.46 & 5.43 & 9.89 & 22.42 & 64.08 \\
\hline Middle East and North Africa & 7.31 & 7.36 & 14.67 & 36.74 & 43.31 \\
\hline
\end{tabular}

Notes: The model is estimated over the 1985-2010 period and the variance decompositions are computed for each country, for output, consumption and investment. The cross-sectional mean of the variance share (in percent) attributable to the relevant factor is reported in each cell. The cross-sectional means are calculated for the world and relevant region indicated in the first column. The column marked "Global+Regional" denotes the sums of the average variance shares of the global and regional factors. 
Table 4. Variance Decompositions for the World (Different Breaks)

\begin{tabular}{|c|c|c|c|c|c|}
\hline \multirow[b]{2}{*}{ Variables / Regions } & \multicolumn{5}{|c|}{ Factors } \\
\hline & Global & Regional & $\begin{array}{c}\text { Global + } \\
\text { Regional }\end{array}$ & Country & Idiosyncratic \\
\hline \multicolumn{6}{|l|}{ Benchmark } \\
\hline \multicolumn{6}{|l|}{ 1960-1984 } \\
\hline Output & 13.40 & 10.68 & 24.08 & 41.00 & 32.56 \\
\hline Consumption & 10.57 & 8.24 & 18.81 & 36.95 & 41.78 \\
\hline Investment & 6.12 & 9.55 & 15.67 & 27.99 & 54.00 \\
\hline \multicolumn{6}{|l|}{$1985-2010$} \\
\hline Output & 9.16 & 19.46 & 28.63 & 34.61 & 33.53 \\
\hline Consumption & 6.49 & 13.85 & 20.34 & 30.38 & 46.31 \\
\hline Investment & 8.58 & 15.72 & 24.30 & 29.12 & 43.79 \\
\hline \multicolumn{6}{|l|}{ Break $=1983$} \\
\hline \multicolumn{6}{|l|}{$1960-1983$} \\
\hline Output & 13.91 & 9.71 & 23.63 & 41.04 & 32.77 \\
\hline Consumption & 11.29 & 8.19 & 19.48 & 36.38 & 41.36 \\
\hline Investment & 6.50 & 9.12 & 15.62 & 27.65 & 54.13 \\
\hline \multicolumn{6}{|l|}{ 1984-2010 } \\
\hline Output & 8.19 & 20.45 & 28.64 & 35.67 & 32.98 \\
\hline Consumption & 5.16 & 15.40 & 20.56 & 30.30 & 46.31 \\
\hline Investment & 6.65 & 18.16 & 24.82 & 28.13 & 44.48 \\
\hline \multicolumn{6}{|l|}{ Break $=1987$} \\
\hline \multicolumn{6}{|l|}{ 1960-1987 } \\
\hline Output & 13.72 & 9.07 & 22.79 & 42.22 & 32.80 \\
\hline Consumption & 10.39 & 6.79 & 17.18 & 37.38 & 43.09 \\
\hline Investment & 5.89 & 9.23 & 15.11 & 28.09 & 54.66 \\
\hline \multicolumn{6}{|l|}{ 1988-2010 } \\
\hline Output & 13.74 & 18.76 & 32.51 & 32.88 & 32.40 \\
\hline Consumption & 8.30 & 15.96 & 24.26 & 29.47 & 44.21 \\
\hline Investment & 12.15 & 14.81 & 26.96 & 27.94 & 43.02 \\
\hline
\end{tabular}

Notes: The model is estimated over the periods stated in the first column and the variance decompositions are computed for each country, for output, consumption and investment. The cross-sectional mean of the variance share (in percent) attributable to the relevant factor is reported in each cell. The cross-sectional means are calculated for the world. The column marked "Global+Regional" denotes the sums of the average variance shares of the global and regional factors. 
Table 5. Variance Decompositions for the World (Different End Years)

\begin{tabular}{|c|c|c|c|c|c|}
\hline \multirow[b]{2}{*}{ Variables / Regions } & \multicolumn{5}{|c|}{ Factors } \\
\hline & Global & Regional & $\begin{array}{c}\text { Global + } \\
\text { Regional } \\
\end{array}$ & Country & Idiosyncratic \\
\hline \multicolumn{6}{|l|}{ Benchmark } \\
\hline \multicolumn{6}{|l|}{ 1960-1984 } \\
\hline Output & 13.40 & 10.68 & 24.08 & 41.00 & 32.56 \\
\hline Consumption & 10.57 & 8.24 & 18.81 & 36.95 & 41.78 \\
\hline Investment & 6.12 & 9.55 & 15.67 & 27.99 & 54.00 \\
\hline \multicolumn{6}{|l|}{$1985-2010$} \\
\hline Output & 9.16 & 19.46 & 28.63 & 34.61 & 33.53 \\
\hline Consumption & 6.49 & 13.85 & 20.34 & 30.38 & 46.31 \\
\hline Investment & 8.58 & 15.72 & 24.30 & 29.12 & 43.79 \\
\hline \multicolumn{6}{|l|}{ End Year $=2007$} \\
\hline \multicolumn{6}{|l|}{ 1985-2007 } \\
\hline Output & 6.25 & 17.24 & 23.50 & 36.99 & 34.13 \\
\hline Consumption & 4.76 & 12.89 & 17.65 & 32.23 & 45.31 \\
\hline Investment & 5.01 & 14.54 & 19.55 & 32.43 & 43.58 \\
\hline \multicolumn{6}{|l|}{ End Year $=2015$} \\
\hline \multicolumn{6}{|l|}{$1985-2015$} \\
\hline Output & 10.82 & 19.76 & 30.58 & 33.87 & 33.48 \\
\hline Consumption & 6.70 & 13.74 & 20.44 & 29.66 & 47.93 \\
\hline Investment & 10.25 & 14.52 & 24.77 & 27.35 & 45.99 \\
\hline
\end{tabular}

Notes: The model is estimated over the periods stated in the first column and the variance decompositions are computed for each country, for output, consumption and investment. The cross-sectional mean of the variance share (in percent) attributable to the relevant factor is reported in each cell. The cross-sectional means are calculated for the world. The column marked "Global+Regional" denotes the sums of the average variance shares of the global and regional factors. Data for 2011-15 are the forecasts from the IMF's World Economic Outlook (April, 2011). 
Figure 1. Average Variance Explained by Global and Regional Factors (1960-2010)

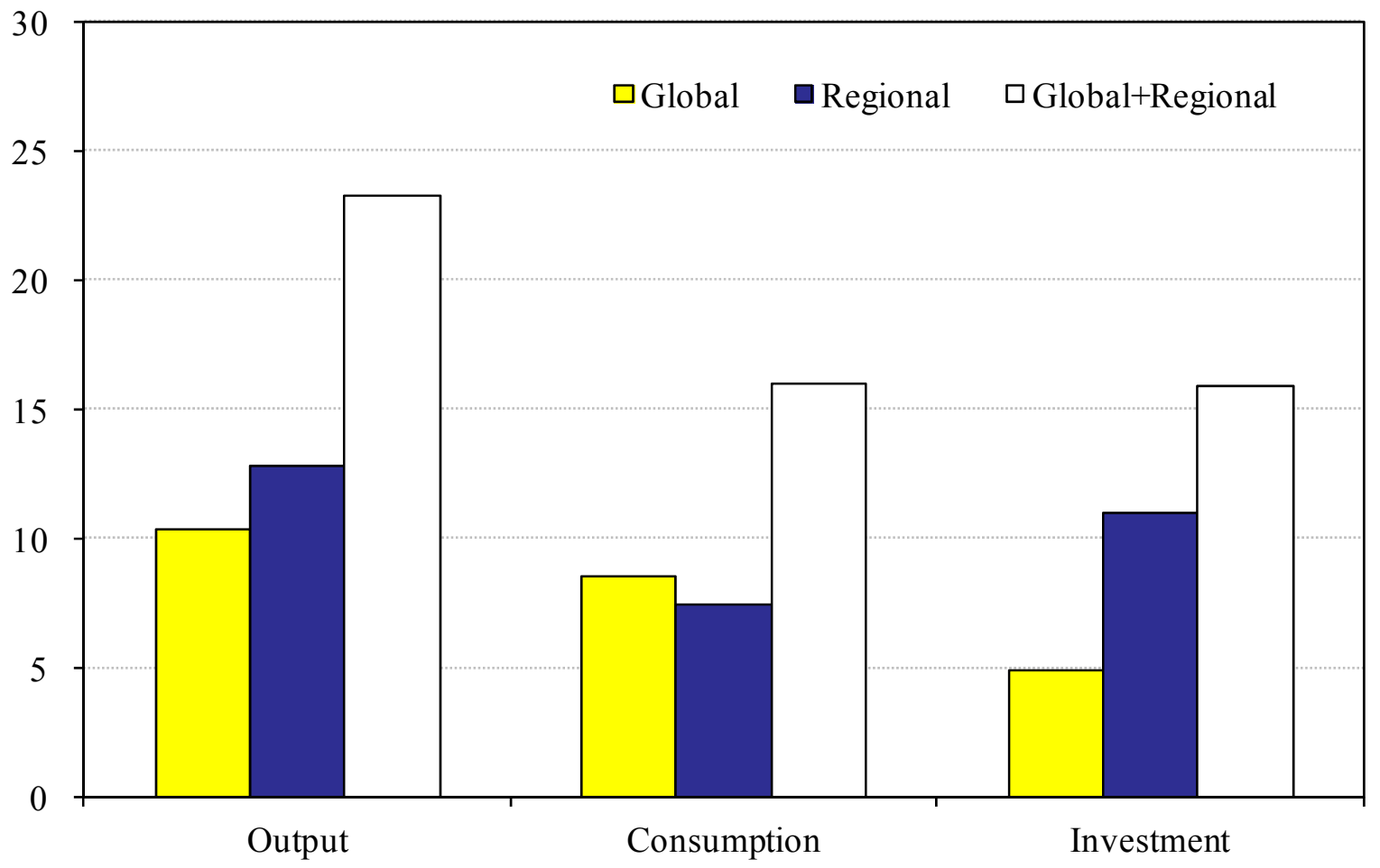

Notes: We estimate the model over the full sample period (1960-2010) and compute the variance decompositions for each country, separately for output, consumption and investment. Each bar then represents the cross-sectional mean of the variance share attributable to the relevant factor for that particular variable. The cross-sectional means are calculated over the full sample of countries. The bar marked "Global+Regional" represents the sum of the average variance shares of the global and regional factors for each variable. 
Figure 2. Variance Explained by Global Factor
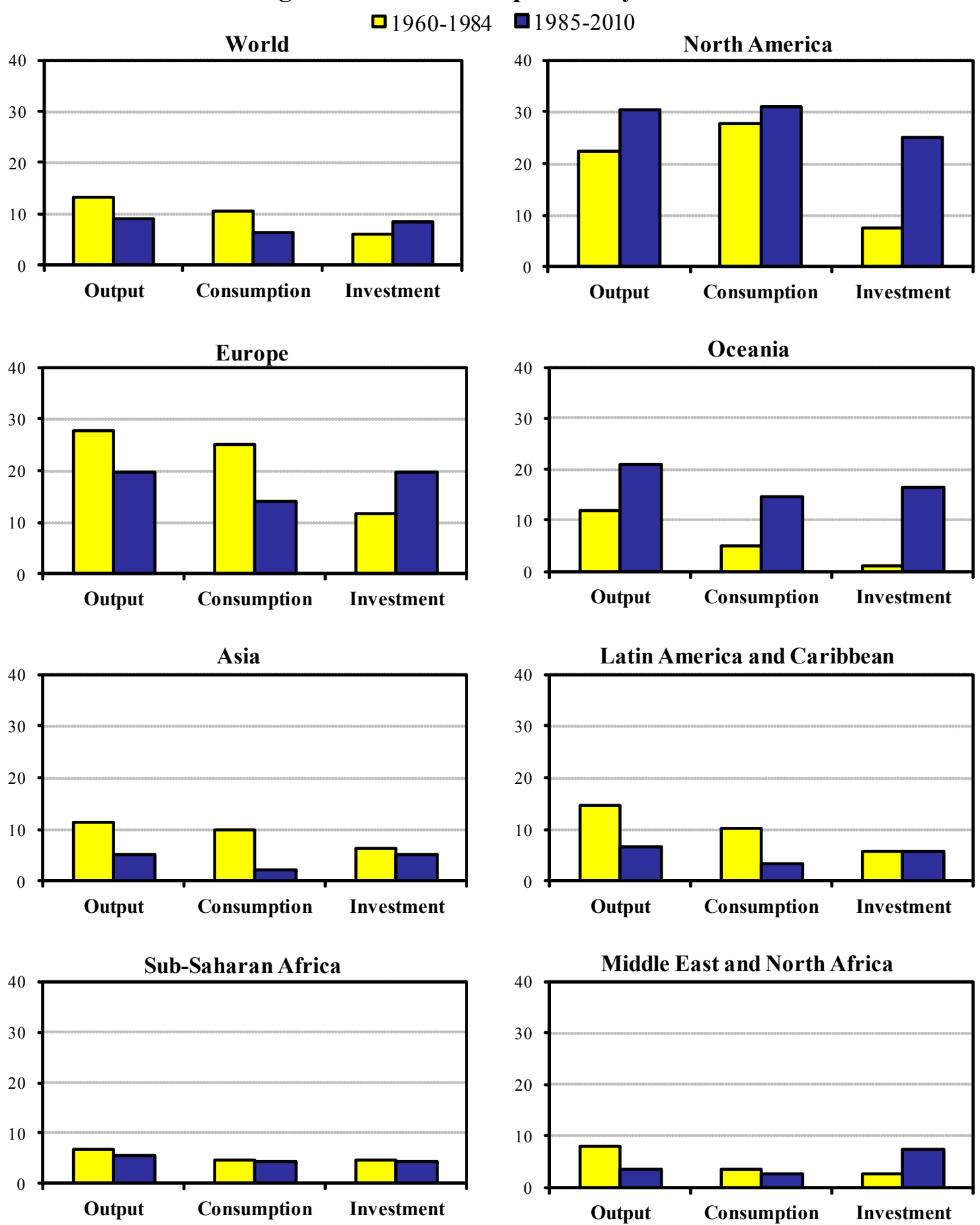

Notes: We estimate the model separately over the two periods, 1960-84 (yellow) and 1985-2010 (blue). We then compute the variance decompositions for each country for output, consumption and investment. Each bar then represents the cross-sectional mean of the variance share attributable to the regional factor for that particular variable in a given period. The cross-sectional means are calculated for the relevant regions. 
Figure 3. Variance Explained by Regional Factors
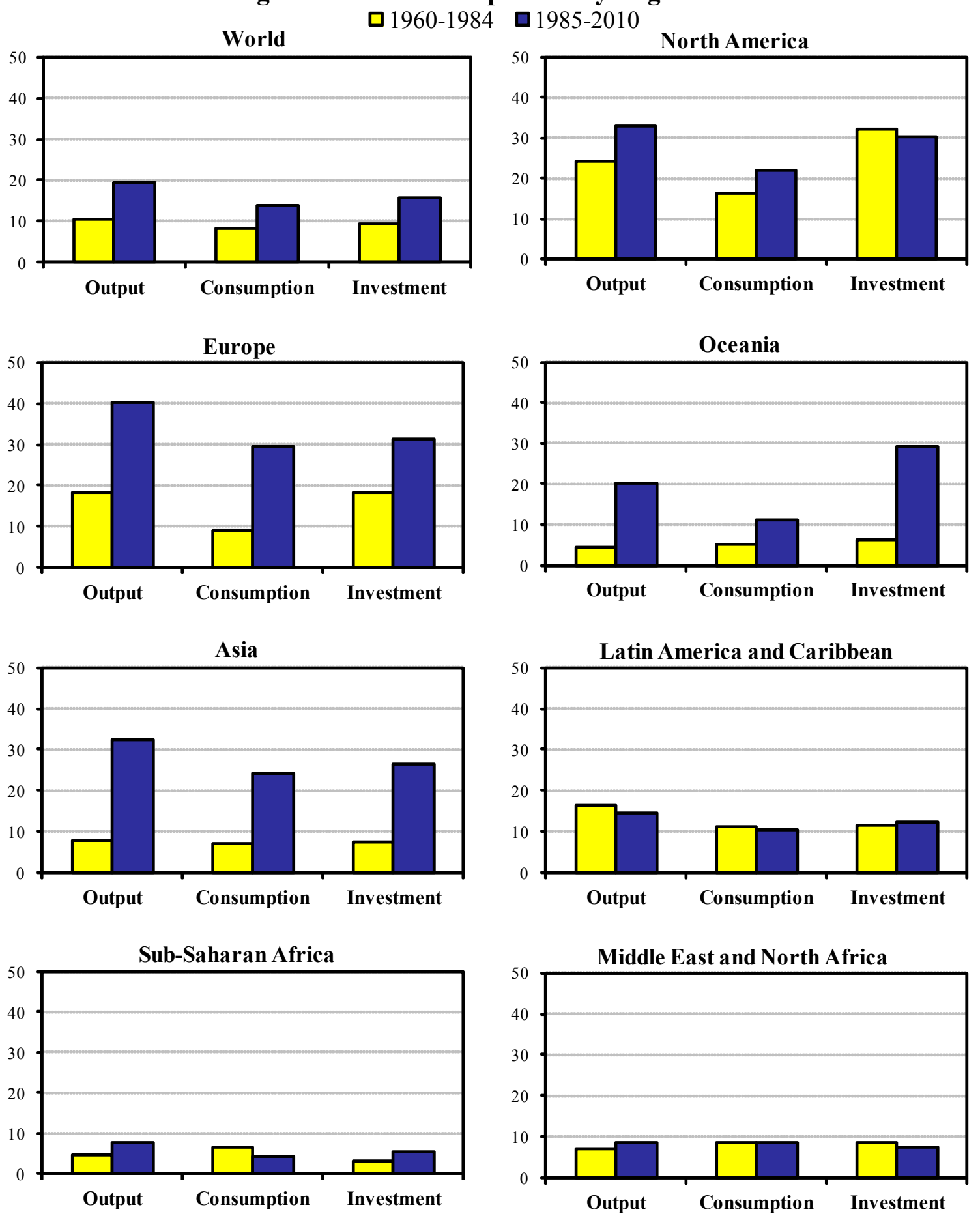

Notes: We estimate the model separately over the two periods, 1960-84 (yellow) and 1985-2010 (blue). We then compute the variance decompositions for each country for output, consumption and investment. Each bar then represents the cross-sectional mean of the variance share attributable to the regional factors for that particular variable in a given period. The cross-sectional means are calculated for the relevant regions. 
Figure 4. Variance Explained by Global and Regional Factors

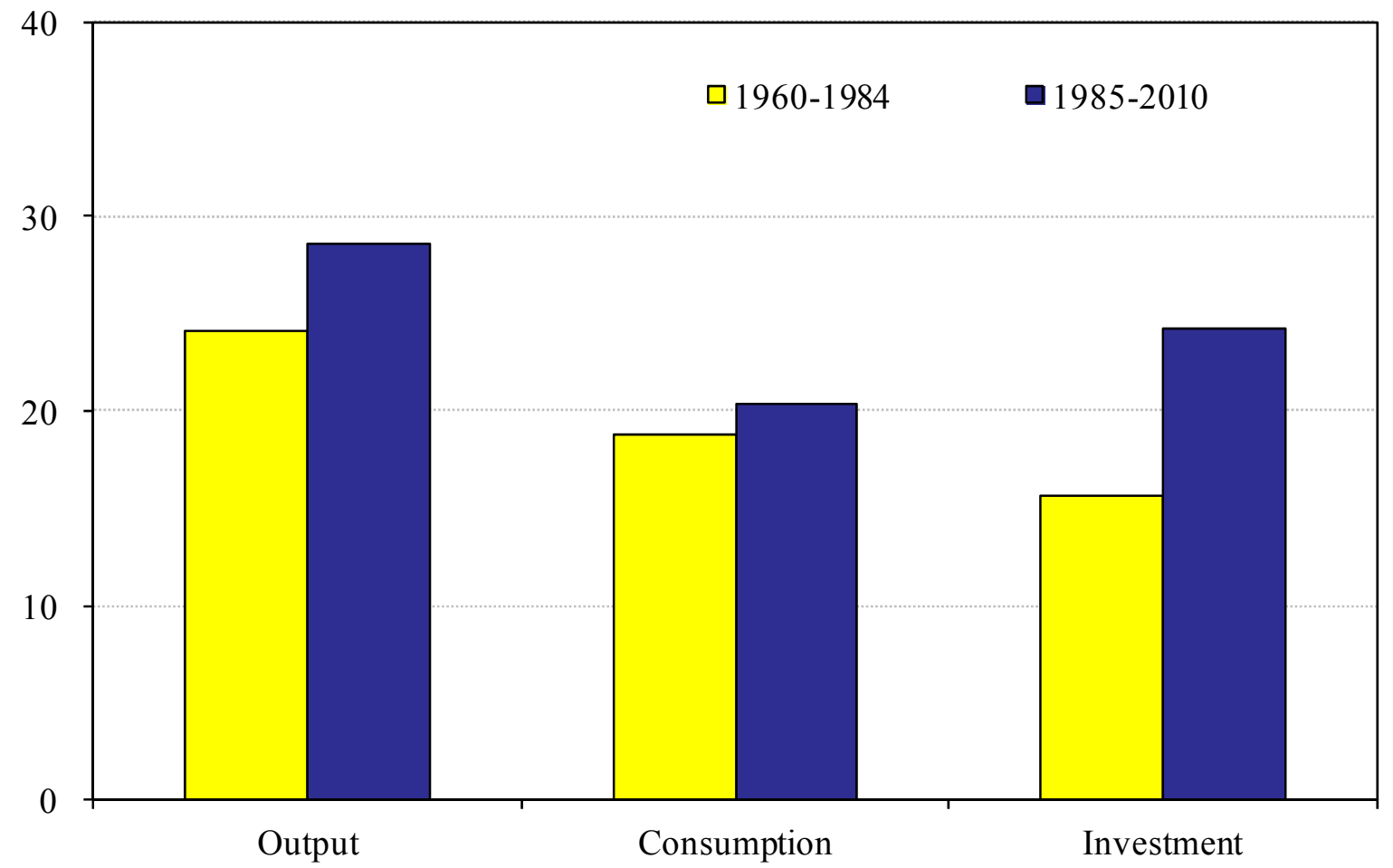

Notes: We estimate the model separately over the two periods, 1960-84 (yellow) and 19852010 (blue). We then compute the variance decompositions for each country, for output, consumption and investment in each of these two periods. Each bar then represents the crosssectional mean of the variance share attributable to the sum of the global and regional factors for that particular variable in a given period. 
Figure 5. Output Variance Explained by Global Factor

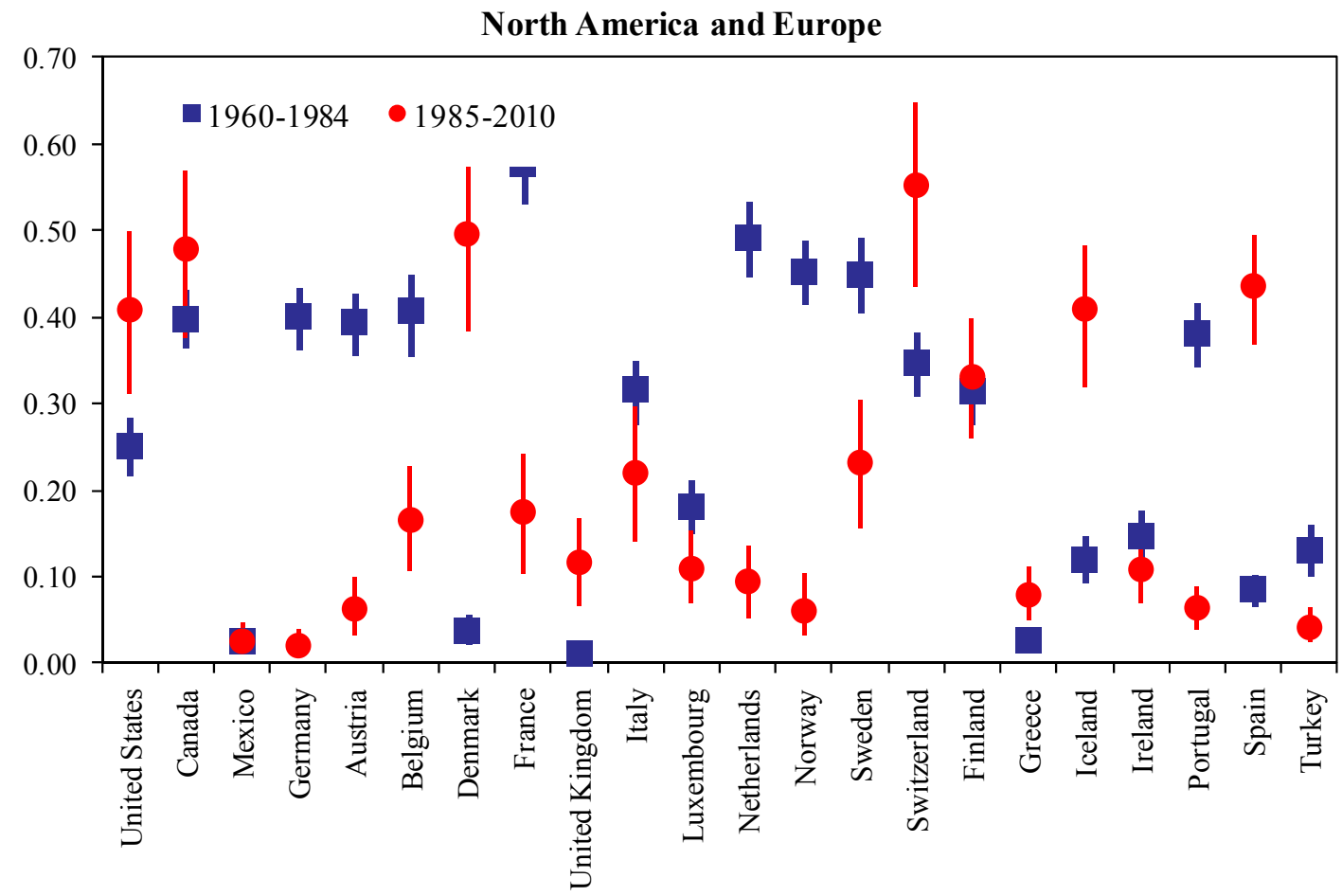

Asia and Oceania

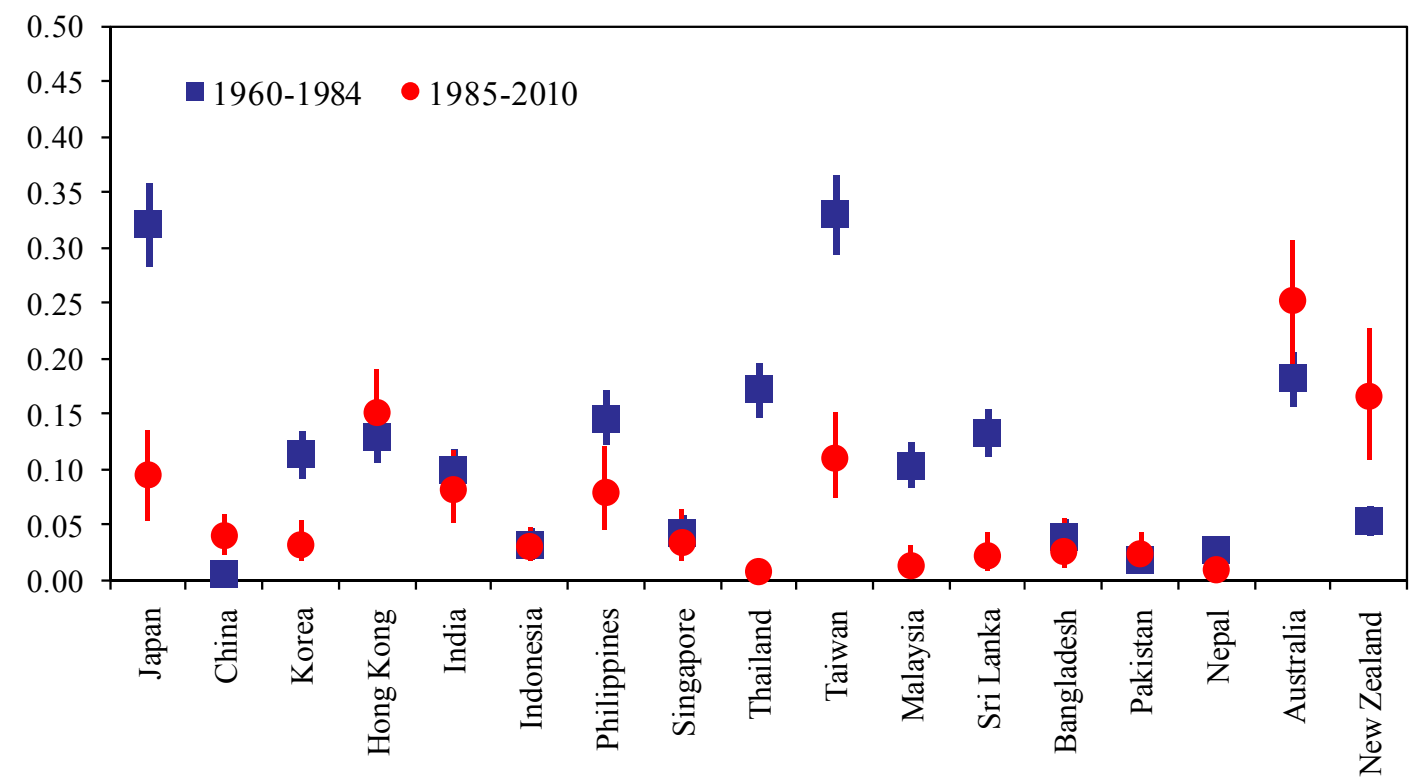

Notes: We estimate the model separately over the two periods, 1960-84 and 1985-2010. For each country, we then show the posterior means of the share of the variance of output growth fluctuations accounted for. We also show the corresponding posterior coverage intervals of length two standard deviations (\%). 
Figure 6. Output Variance Explained by Regional Factor
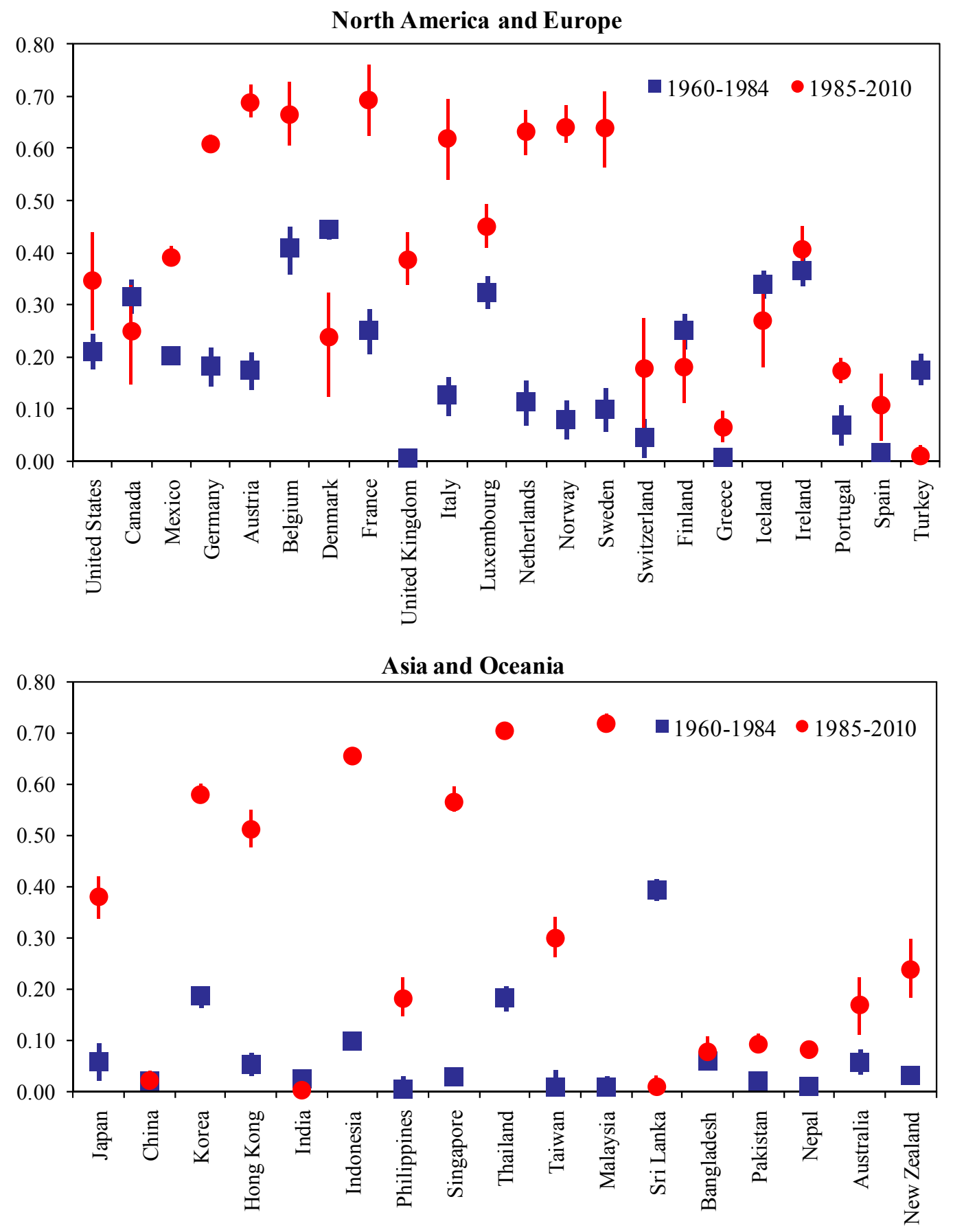

Notes: See notes of Figure 5. 


\section{Appendix I: List of Regions and Countries}

\begin{tabular}{l|l}
\hline Region & Countries \\
\hline Eurth America (3) & $\begin{array}{l}\text { United States, Canada, Mexico } \\
\text { Germany, Austria, Belgium, Finland, France, Ireland, Italy, } \\
\text { Luxembourg, Netherlands, Portugal, Spain, United Kingdom, } \\
\text { Denmark, Norway, Sweden, Switzerland, Greece, Iceland, Turkey }\end{array}$ \\
$\begin{array}{l}\text { Oceania (2) } \\
\text { Latin America and } \\
\text { the Caribbean (22) }\end{array}$ & $\begin{array}{l}\text { Argentina, Bolivia, Brazil, Chile, Colombia, Ecuador, Guyana, } \\
\text { Paraguay, Peru, Uruguay, Venezuela, RB, Costa Rica, El Salvador, } \\
\text { Guatemala, Honduras, Nicaragua, Jamaica, Barbados, Dominican } \\
\text { Republic, Haiti, Panama, Trinidad and Tobago }\end{array}$ \\
Asia (15) & $\begin{array}{l}\text { Japan, China, Korea, Hong Kong, India, Indonesia, Philippines, } \\
\text { Singapore, Thailand, Taiwan, Malaysia, Sri Lanka, Bangladesh, } \\
\text { Pakistan, Nepal }\end{array}$ \\
$\begin{array}{l}\text { Sub-Saharan Africa } \\
\text { (37) }\end{array}$ & $\begin{array}{l}\text { South Africa, Botswana, Cape Verde, Lesotho, Mali, Mauritius, } \\
\text { Mozambique, Congo, Dem. Rep., Rwanda, Seychelles, Tanzania, } \\
\text { Uganda, Zambia, Ghana, Ethiopia, Cameroon, Chad, Comoros, Congo, } \\
\text { Rep., Benin, Equatorial Guinea, Gabon, Gambia, The, Guinea-Bissau, } \\
\text { Guinea, Cote d'Ivoire, Kenya, Madagascar, Malawi, Mauritania, Niger, } \\
\text { Nigeria, Senegal, Togo, Burkina Faso, Zimbabwe, Burundi }\end{array}$ \\
North Africa (8) & $\begin{array}{l}\text { Israel, Iran Islamic Rep., Jordan, Syrian Arab Republic, Egypt Arab } \\
\text { Rep., Algeria, Morocco, Tunisia }\end{array}$ \\
\hline
\end{tabular}

Data Sources: Primarily from the World Bank's World Development Indicators (WDI), supplemented with the International Monetary Fund's World Economic Outlook (WEO) database. 


\section{Appendix II. Summary of Empirical Studies on Synchronization of Cycles in Different Regions}

\begin{tabular}{|c|c|c|c|c|}
\hline Authors & Country Sample & Variables/ Period & Methodology & Objective ( O ) and Results ( R ) \\
\hline $\begin{array}{l}\text { Abeysinghe and Forbes } \\
\text { (2005) }\end{array}$ & $\begin{array}{l}\text { USA, IDN, MYS, PHL, THA, HKG, } \\
\text { SGP, KOR, TWN, CHN, JPN and } \\
\text { the rest of OECD countries }\end{array}$ & $\begin{array}{l}\text { Real output } \\
1975-1998\end{array}$ & SVAR & $\begin{array}{l}\text { (O) Estimate the effects of trade linkages and indirect multiplier effects transmitting } \\
\text { shocks across countries. } \\
\text { (R) The multiplier effects in Asia tend to be large. }\end{array}$ \\
\hline Allegret and Essaadi (2011) & $\begin{array}{l}\text { SGP, MYS,IDN, THA, PHL, TWN, } \\
\text { HKG, CHN, JPN, KOR, USA }\end{array}$ & $\begin{array}{l}\text { Real output } \\
\text { 1975Q1-2007Q1 }\end{array}$ & $\begin{array}{l}\text { Time varying cohesion } \\
\text { approach }\end{array}$ & $\begin{array}{l}\text { (O) Analyze the feasibility of a monetary union in East Asia. } \\
\text { (R) There is a common cycle in East Asia, but it is heavily influenced by external } \\
\text { factors. The degree of coherence of cycles is significant at the longer frequencies but } \\
\text { insignificant at the medium and short frequencies. }\end{array}$ \\
\hline Bacha (2008) & $\begin{array}{l}\text { IDN, THA, MLY, PHL, SGP, MMR, } \\
\text { VNM, KHM, LAO, JPN, CHN, } \\
\text { KOR, AUS, NZL }\end{array}$ & $\begin{array}{l}\text { Real output } \\
1970-2003\end{array}$ & $\begin{array}{l}\text { Structural VAR } \\
\text { Correlation analysis }\end{array}$ & $\begin{array}{l}\text { (O) Examine the feasibility of a Common Currency Area (CCA) for the ASEAN and } \\
\text { the broader ASEAN }+5 \text {. } \\
\text { (R) No common shock is reported, but some countries exhibit similarities in business } \\
\text { cycles probably due to the geographic proximity. }\end{array}$ \\
\hline $\begin{array}{l}\text { Bayoumi, Eichengreen, and } \\
\text { Mauro (2000) }\end{array}$ & $\begin{array}{l}\text { BRN, KHM, IDN, LAO, MYS, } \\
\text { MMR, PHL, SGP, THA, VNM }\end{array}$ & $\begin{array}{l}\text { IP } \\
\text { 1968-1996 (quarterly) }\end{array}$ & SVAR & $\begin{array}{l}\text { (O) Examine the possibility of monetary integration in Asia and ASEAN and } \\
\text { compare the results with the Euro area. } \\
\text { (R) Disturbances are highly correlated across certain ASEAN countries. High } \\
\text { correlation between the aggregate supply disturbances affecting Indonesia, Malaysia, } \\
\text { and Singapore is found, suggesting the possibility of Optimum Currency Area } \\
\text { (OCA). }\end{array}$ \\
\hline $\begin{array}{l}\text { Bayoumi and Eichengreen } \\
(1994,1997,1999)\end{array}$ & $\begin{array}{l}\text { AUS, HKG, IDN, JPN, KOR, MYS, } \\
\text { NZL, PHL, SGP, TWN, THA }\end{array}$ & $\begin{array}{l}\text { Real output } \\
1969-1989\end{array}$ & SVAR & $\begin{array}{l}\text { (O) Explore the possibility of forming a monetary union in Asia. } \\
\text { (R) Some Asian countries have highly correlated aggregate supply or aggregate } \\
\text { demand shocks which lead to synchronization of cycles supporting the formation of } \\
\text { OCAs. }\end{array}$ \\
\hline Chen and Shen (2007) & TWN, JPN, USA & $\begin{array}{l}\text { Real output } \\
\text { 1962Q1-2004Q4 }\end{array}$ & $\begin{array}{l}\text { Granger causality, } \\
\text { Markov-Switching VAR }\end{array}$ & $\begin{array}{l}\text { (O) Examine whether the locomotive hypothesis (a shock in a major country is } \\
\text { typically transmitted abroad) or common shock hypothesis is more relevant in TWN, } \\
\text { JPN, and USA. } \\
\text { (R) Japanese cycles weakly leads those in Taiwan possibly because of the strong } \\
\text { linkages of two countries with the USA. }\end{array}$ \\
\hline Cheung and Yuen (2004) & CHN, JPN, KOR & $\begin{array}{l}\text { Real output } \\
\text { 1993Q4-2001Q4 }\end{array}$ & VECM & $\begin{array}{l}\text { (O) Examine the prospects of forming a currency union among China, Japan, and } \\
\text { Korea. } \\
\text { (R) The three countries share a common stochastic component at both long-run and } \\
\text { short-run horizons. }\end{array}$ \\
\hline Choe (2001) & $\begin{array}{l}\text { CHN, HKG, IDN, JPN, MYS, PHL, } \\
\text { KOR, TWN, THA }\end{array}$ & $\begin{array}{l}\text { Real output } \\
1981-1995\end{array}$ & $\begin{array}{l}\text { Correlation analysis, } \\
\text { regression }\end{array}$ & $\begin{array}{l}\text { (O) Examine the impact of trade linkages in the synchronization of cycles in the } \\
\text { East Asian countries. } \\
\text { (R) Japan plays a significant role in driving the degree of business cycle }\end{array}$ \\
\hline Chow and Kim (2003) & $\begin{array}{l}\text { HKG, IDN, MYS, PHL, SGP, KOR, } \\
\text { TWN }\end{array}$ & $\begin{array}{l}\text { Real output } \\
\text { 1971Q1-1997Q1 }\end{array}$ & Structural VAR & $\begin{array}{l}\text { (O) Examine the feasibility of a Common Currency Area in East Asia. } \\
\text { (R) Regional shocks are less important in East Asia than in European countries. } \\
\text { Business cycles in East Asia are strongly influenced by country specific shocks. } \\
\text { Common currency peg in the region is costly. }\end{array}$ \\
\hline
\end{tabular}




\begin{tabular}{|c|c|c|c|c|}
\hline Authors & Country Sample & Variables/ Period & Methodology & Objective ( $O$ ) and Results ( R ) \\
\hline Cortinhas (2007) & ASEAN 5 & $\begin{array}{l}\text { Real output } \\
1962-1996\end{array}$ & $\begin{array}{l}\text { Frankel and Rose type } \\
\text { regression }\end{array}$ & $\begin{array}{l}\text { (O) Examine whether increasing intra-industry trade and specialization influence the } \\
\text { synchronization of cycles in ASEAN countries. Explore the possibility of a common } \\
\text { currency union. } \\
\text { (R) Increasing intra-industry trade results in higher business cycle comovement in } \\
\text { ASEAN countries. }\end{array}$ \\
\hline Crosby (2003) & $\begin{array}{l}\text { AUS, CHN, HKG, IDN, JPN, MYS, } \\
\text { NZL, PHL, SGP, KOR, TWN, THA, } \\
\text { USA }\end{array}$ & $\begin{array}{l}\text { Real output } \\
1980-1999\end{array}$ & $\begin{array}{l}\text { Correlation analysis, } \\
\text { regression }\end{array}$ & $\begin{array}{l}\text { (O) Explore the sources and extent of business cycle synchronization among Asia- } \\
\text { Pacific economies. } \\
\text { (R) Structural and technological similarities have a positive impact on } \\
\text { synchronization, but trade linkages do not appear to be important. }\end{array}$ \\
\hline Genberg and Siklos (2010) & $\begin{array}{l}\text { CHN, HKG, IDN, JPN, KOR, MYS,. } \\
\text { PHL, SGP, THA, TWN }\end{array}$ & $\begin{array}{l}\text { Real output } \\
\text { 1990Q1-around } 2008 \text { (different } \\
\text { by country) }\end{array}$ & SVAR & $\begin{array}{l}\text { (O) Employ a more sophisticated identification method of demand and supply shocks } \\
\text { in an SVAR model. Include the role fo foreign shocks and allow possible correlation } \\
\text { between domestic aggregate demand and aggregate supply disturbances. } \\
\text { (R) The number of significant correlations shown in the previous studies goes down. }\end{array}$ \\
\hline Girardin (2004) & $\begin{array}{l}\text { CHN, HKG, IDN, JPN, KOR, MYS, } \\
\text { PHL, SGP, TWN, THA }\end{array}$ & $\begin{array}{l}\text { Real output } \\
\text { 1975Q2-2002Q3 }\end{array}$ & Markov-Switching VAR & $\begin{array}{l}\text { (O) Analyze the extent of business cycle comovement in Asian economies at } \\
\text { different phases of the growth cycle. } \\
\text { (R) Japan and some emerging East Asian countries exhibit a high degree of business } \\
\text { cycle synchronization during the growth-recession and rapid-growth regimes, but the } \\
\text { extent of synchronization is quite low during the normal-growth regime. }\end{array}$ \\
\hline Girardin (2005) & $\begin{array}{l}\text { CHN, HKG, IDN, JPN, KOR, MYS, } \\
\text { PHL, SGP, TWN, THA }\end{array}$ & $\begin{array}{l}\text { Real output } \\
\text { 1975Q2-2002Q3 }\end{array}$ & Markov-Switching VAR & $\begin{array}{l}\text { (O) Examine the similarities in the characteristics of growth-cycles in East Asia and } \\
\text { analyze the interactions of cycles between countries in East Asia and those in Japan } \\
\text { and China. } \\
\text { (R) Linkages in the region show different patterns in each regime (the state of the } \\
\text { growth cycle). The impacts of cycles in Japan and China are significant in the region. }\end{array}$ \\
\hline $\begin{array}{l}\text { Hall, Kim, and Buckle } \\
\text { (1998) }\end{array}$ & $\begin{array}{l}\text { NZL, AUS, USA, GBR, GER, JPN, } \\
\text { KOR, TWN, HKG, SGP }\end{array}$ & $\begin{array}{l}\text { Real output } \\
\text { 1977Q2 to 1995Q1 }\end{array}$ & $\begin{array}{l}\text { Correlation } \\
\text { Turning point }\end{array}$ & $\begin{array}{l}\text { (O) Examine the characteristics of business cycles in New Zealand and its trade } \\
\text { partners. } \\
\text { (R) Cycles in New Zealand is more synchronized more with the U.S. cycle than with } \\
\text { those in Asian countries. }\end{array}$ \\
\hline Hall and McDermott (2011) & NZL, AUS & $\begin{array}{l}\text { Real output and real state final } \\
\text { demand } \\
\text { 1985Q3 to 2007Q4 }\end{array}$ & $\begin{array}{l}\text { Unobserved components } \\
\text { approach }\end{array}$ & $\begin{array}{l}\text { (O) Examine the importance of region-specific cycles in Australian States and New } \\
\text { Zealand. } \\
\text { (R) West Australian and New Zealand region-specific growth cycles exhibit different } \\
\text { features relative to the common cycle. }\end{array}$ \\
\hline He and Liao (2010) & $\begin{array}{l}\text { HKG, CHN, IDN, KOR, MYS, PHL, } \\
\text { SGP, TWN, THL and G7 }\end{array}$ & $\begin{array}{l}\text { Real output } \\
\text { 1981Q1-2008Q4 }\end{array}$ & $\begin{array}{l}\text { SVAR with a factor } \\
\text { model }\end{array}$ & $\begin{array}{l}\text { (O) Identify demand and supply factors driving the Asian business cycles. } \\
\text { (R) Cycles in Asia are less synchronized with the global factors than G7 countries } \\
\text { are, but the importance of the global factors has been increasing over the past 10-20 } \\
\text { years. The Asian regional factors, in particular regional supply factor through vertical } \\
\text { trade integration, tend to be more important for Asian countries. }\end{array}$ \\
\hline
\end{tabular}




\begin{tabular}{|c|c|c|c|c|}
\hline Authors & Country Sample & Variables/ Period & Methodology & Objective ( O ) and Results ( R ) \\
\hline Huang and Guo (2006) & $\begin{array}{l}\text { CHN, HKG, IDN, JPN, KOR, MLY, } \\
\text { PHL, SGP, THA }\end{array}$ & $\begin{array}{l}\text { Nominal output / CPI } \\
1970-2002\end{array}$ & Structural VAR & $\begin{array}{l}\text { (O) Examine the feasibility of a Common Currency Area (CCA) for East Asia. } \\
\text { (R) Forming a currency union in the entire region is not ideal, but it is feasible for a } \\
\text { group of countries with similar shocks and cyclical responses. }\end{array}$ \\
\hline Imbs (2011) & $\begin{array}{l}\text { CHN, HKG, JPN, MYS, PHL, SGP, } \\
\text { TWN, IDN, THA, KOR, VNM, and } \\
\text { other } 33 \text { advanced countries. }\end{array}$ & $\begin{array}{l}\text { Real GDP } \\
\text { 1984Q1-2009Q2 }\end{array}$ & Regression & $\begin{array}{l}\text { (O) Examine the dynamics of business cycles in East Asia. } \\
\text { (R) Business cycles appear to be more synchronized when bilateral trade decreases. } \\
\text { Relatively richer countries tend to experience more synchronized cycles during the } \\
2008-09 \text { financial crisis. }\end{array}$ \\
\hline Kumakura (2006) & $\begin{array}{l}\text { AUS, CHN, IND, IDN, JPN, KOR, } \\
\text { MYS, NZL, PHL, SGP, TWN, THA, } \\
\text { USA }\end{array}$ & $\begin{array}{l}\text { Real output } \\
1983-2004\end{array}$ & $\begin{array}{l}\text { Frankel and Rose type } \\
\text { regression }\end{array}$ & $\begin{array}{l}\text { (O) Assess the degree of business cycle comovements among Asia-Pacific } \\
\text { economies. } \\
\text { (R) The degree of specialization in electronics industry is more important than trade } \\
\text { linkages in driving business cycle comovements. }\end{array}$ \\
\hline Keida (2009) & KOR, MYS, PHL, SGP, THA & $\begin{array}{l}\text { Real output and CPI } \\
\text { 1991Q2-2005Q2 }\end{array}$ & $\begin{array}{l}\text { SVAR and Markov } \\
\text { Switching Model }\end{array}$ & $\begin{array}{l}\text { (O) Examine the possibility of a currency union in East Asian countries. } \\
\text { (R) The cross-country correlations of supply shocks are larger than those of demand } \\
\text { shocks leading to more synchronized cycles in the region. The degree of the } \\
\text { synhcronization of cyclical turning points has been increasing over time in the }\end{array}$ \\
\hline Kim, Kim and Wang (2005) & $\begin{array}{l}\text { IDN, MYS, PHL, SGP, THA, HKG, } \\
\text { CHN, KOR, JPN, TWN }\end{array}$ & $\begin{array}{l}\text { Real consumption } \\
1970-2000\end{array}$ & Regression & $\begin{array}{l}\text { (O) Analyze the degree of risk sharing among Asian countries and the OECD } \\
\text { countries. } \\
\text { (R) The degree of risk sharing appears to be low among Asian countries. }\end{array}$ \\
\hline Kim, Kim and Wang (2006) & $\begin{array}{l}\text { IDN, MYS, PHL, SGP, THA, HKG, } \\
\text { CHN, KOR, JPN, TWN }\end{array}$ & $\begin{array}{l}\text { Real output } \\
\text { Real consumption } \\
1971-2000\end{array}$ & SUR & $\begin{array}{l}\text { (O) Analyze consumption smoothing/risk sharing properties in the East Asian } \\
\text { countries. } \\
\text { (R) The degree of risk sharing appears to be low in the region. }\end{array}$ \\
\hline Kim, Lee, and Park (2011) & $\begin{array}{l}\text { CHN, HK, IDN, KOR, MAL, PHI, } \\
\text { SGP, TWN, THA, and G7 }\end{array}$ & $\begin{array}{l}\text { Real output } \\
\text { 1990Q4-2007Q2 }\end{array}$ & Panel VAR & $\begin{array}{l}\text { (O) Study the characteristics of business cycle interdependence between East Asian } \\
\text { countries and developed countries. } \\
\text { (R) G7 originated shocks explain } 10 \text { percent of the variation in the 1990s and around } \\
20 \text { percent in the 2000s. }\end{array}$ \\
\hline Lee (2011) & ASEAN 5, CHN, KOR, and JPN & $\begin{array}{l}\text { Real output } \\
1970-2007\end{array}$ & $\begin{array}{l}\text { Dynamic common factor } \\
\text { model similar to Kose et } \\
\text { al. (2003) }\end{array}$ & $\begin{array}{l}\text { (O) Examine the features of business cycles and identify the causes of shocks during } \\
\text { major events in East Asia. } \\
\text { (R) The country-specific factors (rather than the regional factors) explain the largest } \\
\text { share of output fluctuations in East Asia. The role of the world factor is relatively } \\
\text { minor in emerging Asian countries. }\end{array}$ \\
\hline Lee (2007) & $\begin{array}{l}\text { CHN, HKG, IDN, JPN, KOR, MYS, } \\
\text { PHL, SGP, THA }\end{array}$ & $\begin{array}{l}\text { Real output, unemployment, IP } \\
\text { 1998Q1-2003Q4 }\end{array}$ & $\begin{array}{l}\text { Frankel and Rose type } \\
\text { regression }\end{array}$ & $\begin{array}{l}\text { (O) Analyze the degree of business cycle comovement in East Asian countries and } \\
\text { explore the feasibility of forming a monetary union. } \\
\text { (R) Aggregate bilateral trade intensity appears to have an ambigous impact on the } \\
\text { degree of comovement of Asian business cycles. }\end{array}$ \\
\hline
\end{tabular}




\section{Asia}

$\begin{array}{lllll}\text { Authors } & \text { Country Sample } & \text { Variables/Period } & \text { Methodology } & \text { Objective and Results }\end{array}$

Lee and Azali (2010) IDN, MLY, PHL,
KOR, and JPN

Lee and Azali (2012)

CHN, AUS, CAN, IDN, BEL, MEX, Real output, consumption and JPN $<$ DEN, USA, KOR, FIN, MLY, investment FRA, PHL, DEU, SGP, GRC, THA, 1970-2007 RE, ITA, LUX, NLD, NOR, PRT, ESP, SWE, CHE, GBR

Lee and Koh (2012)

IDN, MLY, PHL, SGP, THA, CHN, Real output KOR, and JPN 1970-2008

Lee, Park, and Shin (2003) IDN, MLY, PHL, SGP, THA, JPN, Real outpu CHN, HKG, KOR, TWN, AUT, 1978-1990 BEL, DEN, FRA, IRE, ITA, NDL, FIN, GRC, DEU, NOR, PRT, ESP, SWE, CHE, GBR, USA, CAN

Moneta and Ruffer (2009) CHN, HKG, IDN, JPN, MYS, PHL, Real output SGP, KOR, TWN, THA

1975Q1-2005Q3

Park and Shin (2009)

CHN, HKG, IDN, JPN, MYS, PHL, SGP, KOR, TWN, THA, USA, EU13

Real output 1990:Q1-1996:Q4 1999:Q1-2002:Q4, 2003:Q1-2006:Q4

Real output

1990Q1-1996Q4, 1999Q12002Q4, 2003Q1-2006Q4

CHN, IDN, JPN LAO, MYS, PHL, Industrial production SGP, KOR, THA, USA, VNM

1989-2003, 1989M1-2004M12
A system GMM approach (O) Assess the dynamic relationships between trade, finance, industrial

using panel procedures. specialization, and business cycle comovements in East Asia

(R) Trade increases the degree of synchronization, whereas industrial specialization and financial integration decrease synchronization.

Dynamic factor model

(O) Analyze the feasibility of a monetary union in East Asia

(R) Country-specific factors are dominant in the region implying that a monetary union is not feasible. However, the share of country specific factors in explaining cycles has been declining whereas the importance of the regional factor has been rising.

Structural VAR

(O) Analyze the feasibility of a monetary union in East Asia.

(R) The structural shocks are less symmetric in East Asia, but the adjustment to shocks is fast. This implies that it is difficult to form a monetary union for the entire region but some of the countries tend to have more synchronized cycles implying the possibility of a union.

Dynamic factor model $\quad$ (O) Study the prospects of an East Asian currency union by focusing on the extent of trade and financial integration.

(R) Regional shocks are important for explaining output fluctuations in the Asian economies. This fact supports the formulation of the currency union. The growth in trade is expected to enhance the role of regional shocks.

Dynamic factor model (O) Examine the dynamics of business cycle comovement in East Asia similar to Monfort et a (2003)

(R) A common factor exists in the region except for China and Japan. Trade linkages and the exogenous factors such as oil prices, appear to be important in explaining the degree of synchronization of business cycles.

Regression analysis similar to Frankel and Rose

(O) Analyze the divergence of business cycles between East Asia and the rest of the world by focusing on the role of intra-regional and extra-regional trade and financial integration.

(R) Emergence of intra-regional trade in East Asia and that of diversified destination of exports make cycles in East Asian countries less synchronized with those of the US. The role of financial integration is ambiguous.

Panel regression

(O) Investigate the effects of intra-regional and extra-regional financial integration on East Asian business cycle synchronization since 1990.

(R) Regional trade linkages enhance the regional comovements of business cycles but financial linkages (defined as high frequency movements of stock prices) do not.

Frankel and Rose type regression
(O) Analyze the changes in the degree of synhronization of East Asian business cycles.

(R) Increase in bilateral trade linkages and the degree of monetary policy coordination have a positive impact on business cycle synchronization in eight Asian countries particularly after the financial crisis. Business cycles in China tend to exhibit different features. 


\begin{tabular}{|c|c|c|c|c|}
\hline Authors & Country Sample & Variables/ Period & Methodology & Objective ( O ) and Results ( R ) \\
\hline$\overline{R a n a ~(2008) ~}$ & $\begin{array}{l}\text { CHN, IDN, JPN MYS, PHL, SGP, } \\
\text { KOR, THA }\end{array}$ & $\begin{array}{l}\text { Industrial production } \\
\text { 1989M1-2004M12 }\end{array}$ & $\begin{array}{l}\text { Shin and Wang (2004) } \\
\text { type of regression }\end{array}$ & $\begin{array}{l}\text { (O) Examine the role of trade linkages in driving the synchronization of business } \\
\text { cycles in the East Asian economies. } \\
\text { (R) Intra-industry trade linkages have a positive impact on business cycle } \\
\text { synchronization. }\end{array}$ \\
\hline $\begin{array}{l}\text { Sato, Zhang, and McAleer } \\
\text { (2004) }\end{array}$ & $\begin{array}{l}\text { CHN, HKG, IDN, JPN, MYS, PHL, } \\
\text { SGP, KOR, TWN, THA, USA, } \\
\text { EU13 }\end{array}$ & $\begin{array}{l}\text { Real output } \\
\text { 1980Q1 to } 2000 \text { Q3 }\end{array}$ & Structural VAR & $\begin{array}{l}\text { (O) Examine the feasibility of monetary integration in East Asia. } \\
\text { (R) Even though some groups of countries appear to be suitable for monetary } \\
\text { integration, but the entire region does not have the necessary features. }\end{array}$ \\
\hline $\begin{array}{l}\text { Sato, Zhang, and McAleer } \\
\text { (2011) }\end{array}$ & $\begin{array}{l}\text { JPN, KOR, TWN, HKG, SGP, } \\
\text { MLY, IDN, THA, PHL, CHN }\end{array}$ & $\begin{array}{l}\text { Real output } \\
\text { 1978Q1-2007Q4 }\end{array}$ & Structural VAR & $\begin{array}{l}\text { (O) Identify the impact of external and internal shocks in explaining the } \\
\text { comovements of macroeconomic variables in East Asia. } \\
\text { (R) Although the region has been becomoing more integrated, shocks originating in } \\
\text { the U.S. are still prominent. Oil prices have been becoiming a less important factor. }\end{array}$ \\
\hline Sato and Zhang (2006) & $\begin{array}{l}\text { CHN, HKG, IDN, JPN, MYS, PHL, } \\
\text { SGP, KOR, TWN, THA, USA }\end{array}$ & Real output,1 978Q1-2004Q4 & $\begin{array}{l}\text { Johansen's } \\
\text { Cointegaration approach }\end{array}$ & $\begin{array}{l}\text { (O) Investigate the extent of regional integration and the suitability of a monetary } \\
\text { union in the East Asian economies. } \\
\text { (R) Short-run common cycles are shared by ASEAN countries, Northeastern } \\
\text { countries, Japan, and Taiwan. Long-run common cycles are shared by NIEs and } \\
\text { Japan, ASEAN countries, and China and Hong Kong. }\end{array}$ \\
\hline Selover (2004) & KOR, JPN & $\begin{array}{l}\text { IP, CPI, interest rates, money, } \\
\text { FOREX } \\
\text { 1960M1-2002M1 }\end{array}$ & SVAR & $\begin{array}{l}\text { (O) Investigate the transmission of business cycles between Korea and Japan. } \\
\text { (R) Cyclical dependence has been rising over time and the Japanese cycles } \\
\text { moderately influence the Korean cycles. }\end{array}$ \\
\hline Selover (1999) & $\begin{array}{l}\text { IDN, MYS, PHL, SGP, THA, USA, } \\
\text { AUS, JPN, EU }\end{array}$ & $\begin{array}{l}\text { Real output } \\
1961-1997\end{array}$ & $\begin{array}{l}\text { SVAR, } \\
\text { Spectral analysis }\end{array}$ & $\begin{array}{l}\text { (O) Examine the extent of the transmission and sychronization of cycles in the } \\
\text { ASEAN countries and their major trading partners. } \\
\text { (R) Little evidence of business cycle transmission within the ASEAN nations and } \\
\text { between ASEAN and its major trading partner advanced economies. The ASEAN } \\
\text { countries appear to share a common cyclical component. }\end{array}$ \\
\hline Shin and Wang (2003) & $\begin{array}{l}\text { CHN, HKG, IDN, JPN, MYS, PHL, } \\
\text { SGP, KOR, TWN, THA, BGD, IND }\end{array}$ & Real output 1976-1997 & $\begin{array}{l}\text { Frankel and Rose type } \\
\text { regression }\end{array}$ & $\begin{array}{l}\text { (O) Examine the role of trade linkages in the comovement of business cycles in Asia. } \\
\text { (R) Stronger intra-industry trade linkages lead to more correlated cycles. }\end{array}$ \\
\hline
\end{tabular}




\section{Asia}

\begin{tabular}{|c|c|c|c|c|}
\hline Auth & Country Sample & Variables/ Period & Methodology & Obiective ( $O$ ) and Results ( $R$ ) \\
\hline
\end{tabular}

$\begin{array}{lll}\text { Shin and Wang (2004) } & \text { CHN, HKG, IDN, JPN, MYS, PHL, } & \text { Real output 1976-1997 Frankel and Rose type }\end{array}$

SGP, KOR, TWN, THA, BGD, IND

Shin and Sohn (2006)

CHN, HKG, IDN, JPAN, KOR,

MYS, PHL, SGP, THA

CPI

$1971-2003$

CHN, HKG, IDN, JPN, KOR, MYS, Real output

PHL, SGP, TWN, THA

1985Q2-1997Q4

1998Q3-2003Q4

Weber (2009)

AUS, NZL, HKG, SGP, KOR,

Real output

gression

(O) Examine the business cycle linkages betwee Korea and other Asian countries.

(R) Stronger intra-industry trade linkages improve business cycle comovement

between Korea and other Asian countries.

O) Examine the role of financial and trade integration on business cycle synchronization, price comovement, and risk sharing.

(R) Trade integration leads to output comovement but does not lead to consumption comovement in East Asia. The role of financial integration proxied by interest rate correlations is minor.

Dynamic factor model

(O) Examine the commonality of cycles among the East Asian economies.

(R) Business cycle correlation between Japan and East Asia has been increasing after the mid-90s. Japan shares 75 percent of output variation with the region in the first sample period, while it shares just 3 percent in the second sample period. In the case of the NIEs, their output variation can be attributed to themselves by 13 percent, to regional factor by 42 percent and the global factor seemingly mainly due to the US by 44 percent.

(O) Examine whether the growth of exports and investment drives the dynamics of GDP growth and study the presence of coherence in the Asia-Pacific region.

(R) Growth of exports and investment tend to drive the growth of income in the

region. Shocks to exports and investment have significant impacts on the long-run output and shocks to exports have stronger effects in the case of developing economies.

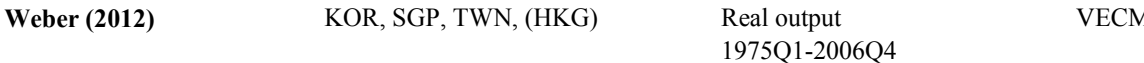

(O) Explore whether South-East Asia shares common cyclical characteristics and analyze the sources of cyclical transmission among them.

(R) There appear to be common cycles among Korea, Singapore, and Taiwan in the long- and medium-run 


\section{Europe}

\begin{tabular}{|c|c|c|c|c|}
\hline Authors & Country Sample & Variables/ Period & Methodology & Objective ( O ) and Results ( R ) \\
\hline $\begin{array}{l}\text { Artis, Chouliarakis, and } \\
\text { Harischandra (2011) }\end{array}$ & $\begin{array}{l}\text { ARG, AUS, AUT, BEL, BRA, CAN, } \\
\text { CHL, DNK, FIN, FRA, DEU, GRC, } \\
\text { IND, ITA, JPN, NLD, NOR, PRT, } \\
\text { ESP, LKA, SWE, CHE, GBR, USA, } \\
\text { URY }\end{array}$ & $\begin{array}{l}\text { Real output } \\
1880-2006\end{array}$ & $\begin{array}{l}\text { Correlation analysis } \\
\text { FSVAR }\end{array}$ & $\begin{array}{l}\text { (O) Examine the historical international business cycles. } \\
\text { (R) European group and English-speaking (Anglo-Saxon) group show an increase in } \\
\text { the degree of synchronization of cycles after the WWII, which has been enhanced by } \\
\text { the increase in trade. In the other country groups, idiosyncratic shocks are still } \\
\text { dominant. }\end{array}$ \\
\hline $\begin{array}{l}\text { Artis, Dreger, and } \\
\text { Kholodilin (2011) }\end{array}$ & $\begin{array}{l}41 \text { regions of BEL, DEU, ESP, FRA, } \\
\text { ITA, LUX, NLD, AUT, PRT }\end{array}$ & $\begin{array}{l}\text { Gross Value Added } \\
1982-2007\end{array}$ & $\begin{array}{l}\text { Panel model with spatial } \\
\text { effects }\end{array}$ & $\begin{array}{l}\text { (O) Check the tendency for national business cycles to converge after the 1960s is } \\
\text { also applicable to the regional level data. } \\
\text { (R) Business cycle convergence at regional level in European countries using euro is } \\
\text { not confirmed. Cyclical heterogeneity is reported. }\end{array}$ \\
\hline $\begin{array}{l}\text { Artis, Marcello, and } \\
\text { Proietti (2004) }\end{array}$ & GER, FRA, ITA, GBR, USA & $\begin{array}{l}\text { IP } \\
\text { Around 1960-2001 } \\
\text { Real output and its components } \\
\text { 1970-2001 }\end{array}$ & $\begin{array}{l}\text { Dating methods (One is } \\
\text { HP (2002) type and the } \\
\text { other is original) }\end{array}$ & $\begin{array}{l}\text { (O) Develop a dating algorithm based on Markov chains that enforces alternation of } \\
\text { peaks and troughs and duration constraints. } \\
\text { (R) Using deviation (filtered) cycles, high synchronization within the Euro area is } \\
\text { reported. Using classical cycles, country pair concordances among Germany, France } \\
\text { and Italy appear to be high. }\end{array}$ \\
\hline Artis and Siebert (2004) & $\begin{array}{l}\text { AUT, FIN, FRA, GER, ITA, ESP, } \\
\text { SWE, GBR, EU15, USA, CAN, } \\
\text { JPN, CHE, AUS, KOR, NDL, PRT, } \\
\text { NOR, BEL, MEX, NZL, DNK, IRN }\end{array}$ & $\begin{array}{l}\text { Real GDP } \\
1970-2001\end{array}$ & $\begin{array}{l}\text { Classical } \\
\text { Multidimensional scaling, } \\
\text { Panel regression }\end{array}$ & $\begin{array}{l}\text { (O) Identify European cycles and check which country belongs to it by using } \\
\text { classical multidimensional scaling and clustering and study the determinants of } \\
\text { synchronization. } \\
\text { (R) A unique European cycle has not emerged over time. The financial structure and } \\
\text { the share of oil imports can explain the business cycle correlations between some } \\
\text { European countries and Germany (or the U.S.). }\end{array}$ \\
\hline Artis and Zhang (1997) & $\begin{array}{l}\text { USA, JPN, CAN, GBR, FIN, NOR, } \\
\text { SWE, GER, FRA, ITA, NDL, BEL, } \\
\text { ESP, PRT, IRL }\end{array}$ & $\begin{array}{l}\text { IP } \\
\text { 1961M1- 1993M12 (pre-ERM } \\
\text { period (1961M1-1979M3) and } \\
\text { the ERM period } \\
(1979 \text { M4-1993M12)) }\end{array}$ & $\begin{array}{l}\text { Simple correlation with } \\
\text { various methods of } \\
\text { filtering }\end{array}$ & $\begin{array}{l}\text { (O) Investigate how the Exchange-Rate Mechanism of the EMS affects the business } \\
\text { cycle synchronization. } \\
\text { (R) Business cycles of EMS countries are more synchronized with German cycles } \\
\text { and less synchronized with the US cycles. }\end{array}$ \\
\hline Artis and Zhang (1999) & $\begin{array}{l}\text { USA, JPN, CAN, GBR, FIN, NOR, } \\
\text { SWE, GER, FRA, ITA, NDL, BEL, } \\
\text { ESP, PRT, IRL, LUX, GRC, CHE, } \\
\text { IRE }\end{array}$ & $\begin{array}{l}\text { IP } \\
\text { 1961M1- 1995M10 (pre-ERM } \\
\text { period (1961M1-1979M3) and } \\
\text { the ERM period } \\
(1979 \text { M4-1995M10)) }\end{array}$ & $\begin{array}{l}\text { Non-parametric rank } \\
\text { correlation }\end{array}$ & $\begin{array}{l}\text { (O) Investigate how the Exchange-Rate Mechanism of the EMS affects the business } \\
\text { cycle synchronization. } \\
\text { (R) Business cycles of EMS countries are more synchronized with German cycles } \\
\text { and less synchronized with the US cycles. }\end{array}$ \\
\hline Babetskii(2005) & $\begin{array}{l}\text { BGR, CZE, EST, HUN, LVA, LTU, } \\
\text { POL, ROU, SVK, SVN, GER, } \\
\text { EU15, USA,IRL, PRT, ESP }\end{array}$ & $\begin{array}{l}\text { Real output } \\
\text { 1990Q1-2002Q2 }\end{array}$ & SVAR & $\begin{array}{l}\text { (O) Measure the degree of shock asymmetry between the EU and the candidate } \\
\text { countries to examine the effects of economic integration on the synchronization of } \\
\text { shocks . } \\
\text { (R) Higher symmetry of demand shocks is due to an increase in trade intensity. The } \\
\text { impact of integration on the symmetry of supply shock is ambiguous. }\end{array}$ \\
\hline
\end{tabular}




\begin{tabular}{|c|c|c|c|c|}
\hline Authors & Country Sample & Variables/ Period & Methodology & Objective ( O ) and Results ( R ) \\
\hline $\begin{array}{l}\text { Bayoumi and Eichengreen } \\
\text { (1993) }\end{array}$ & $\begin{array}{l}\text { GER, FRA, BEL, NDL, DNK, GBR, } \\
\text { ITA, ESP, IRL, POR, GRC }\end{array}$ & $\begin{array}{l}\text { Real and nominal output (and } \\
\text { prices) } \\
1960-1988\end{array}$ & SVAR & $\begin{array}{l}\text { (O) Identify supply and demand disturbances of the EU economies, compare them } \\
\text { with those of the US regions, and discuss the possibility of sound operation of the } \\
\text { monetary union. } \\
\text { (R) A core group of EU countries (Germany + neighbors) share underlying shocks } \\
\text { of similar magnitude and cohesion, but the EU as a whole does not exhibit the some } \\
\text { properties. }\end{array}$ \\
\hline Belke and Heine (2006) & $\begin{array}{l}\text { A panel of } 31 \text { regions from BEL, } \\
\text { FRA, GER, IRL, NDL, ESP }\end{array}$ & $\begin{array}{l}\text { Employment } \\
1975-1997\end{array}$ & Panel regression & $\begin{array}{l}\text { (O) Examine the impact of regional specialization patterns on the synchronicity of } \\
\text { regional employment cycles to analyze the challenges of conducting a common } \\
\text { monetary policy in the Euro zone. } \\
\text { (R) Sector similarity is the key for synchronization of cycles. Specialization has a } \\
\text { significant on the correlations of regional employment cycles in the EU. Core-EMU } \\
\text { tends to change into two pairs of regions. On the one hand, there are regions } \\
\text { converging and displaying increasingly more synchronous employment cycles. }\end{array}$ \\
\hline Belke and Heine (2007) & $\begin{array}{l}\text { A panel of } 31 \text { regions from BEL, } \\
\text { FRA, GER, IRL, NDL, ESP }\end{array}$ & $\begin{array}{l}\text { Employment } \\
1975-1997\end{array}$ & Pooled regression & $\begin{array}{l}\text { (O) Test the degree of regional specialization patterns on the synchronicity of } \\
\text { regional employment cycles. } \\
\text { (R) Core-EMU will tend to change into two types of regions by converging to each } \\
\text { other and the opposite. The degree of comovement has decreased in the past for the } \\
\text { majority of countries. }\end{array}$ \\
\hline $\begin{array}{l}\text { Camacho, Perez-Quiros, } \\
\text { Saiz (2008) }\end{array}$ & $\begin{array}{l}\text { BEL, DEN, FRA, GER, ITA, LUX, } \\
\text { NDL, PRT, ESP, GBR, AUT, FIN, } \\
\text { SWE, CYP, EST, LVA, LTU, POL, } \\
\text { SVK, SVN, CZE, HUN, ROU, TUR, } \\
\text { CAN, JPN, NOR, USA }\end{array}$ & $\begin{array}{l}\text { IP } \\
\text { 1962M1(or 1990M1)-2004M3 }\end{array}$ & $\begin{array}{l}\text { Stationary bootstrap and } \\
\text { model-based clustering } \\
\text { methods, similar to Artis }\end{array}$ & $\begin{array}{l}\text { (O) Offer a comprehensive framework to analyze business cycle characteristics (eg. } \\
\text { similarities or differences) other than synchronization. } \\
\text { (R) There is evidence against the existence of just one European cycle. There are } \\
\text { multiple clusters in business cycles of European economies. }\end{array}$ \\
\hline $\begin{array}{l}\text { Camacho, Perez-Quiros, } \\
\text { Saiz (2006) }\end{array}$ & $\begin{array}{l}\text { AUT, BEL, GER, GRC, FIN, FRA, } \\
\text { ITA, IRN, LUX, NDL, PRT, ESP, } \\
\text { CYP, CZE, EST, HUN, LVA, LTU, } \\
\text { MLT, POL, SVK, CAN, NOR, JPN, } \\
\text { USA, DEN, SWE, GBR, BUL, } \\
\text { ROU, TUR }\end{array}$ & $\begin{array}{l}\text { IP } \\
\text { 1990M1-2003M1 }\end{array}$ & $\begin{array}{l}\text { Clustering techniques and } \\
\text { classical } \\
\text { multidimensional scaling }\end{array}$ & $\begin{array}{l}\text { (O) Examine whether the cycles in Europe driven by a common factor. } \\
\text { (R) There is no leading country in driving the regional cycles. }\end{array}$ \\
\hline $\begin{array}{l}\text { Canova and Schlaepfer } \\
\text { (2011) }\end{array}$ & $\begin{array}{l}\text { DZA, CYP, EGY, FRA, GRC, ISR, } \\
\text { ITA, JOR, LBN, MLT, MKD, MAR, } \\
\text { PRT, SRB, SVN, ESP, TUN TUR }\end{array}$ & $\begin{array}{l}\text { Real output, unemployment, IP, } \\
\text { real income, real sales } \\
1961-2009\end{array}$ & $\begin{array}{l}\text { Dating method (date then } \\
\text { average approach) }\end{array}$ & $\begin{array}{l}\text { (O) Construct turning points of macro variables for the Mediterranean economies } \\
\text { and examine the role of trade in driving the synchronization of the cycles in the } \\
\text { region. } \\
\text { (R) The role of trade on the degree of business cycle synchronicity in the } \\
\text { Mediterranean basin is limited. Financial interdependencies also do not play a key } \\
\text { role. }\end{array}$ \\
\hline
\end{tabular}




\section{Europe}

\begin{tabular}{|c|c|c|c|c|}
\hline Authors & Country Sample & Variables/ Period & Methodology & Objective ( O ) and Results ( R ) \\
\hline $\begin{array}{l}\text { Clark and Van Wincoop } \\
\text { (2001) }\end{array}$ & $\begin{array}{l}\text { AUT, BEL, DNK, FIN, FRA, GER, } \\
\text { GRC, IRL, ITA, NDL, PRT, SPN, } \\
\text { SWE, GBR }\end{array}$ & $\begin{array}{l}\text { Employment 1961-1997 } \\
\text { Real output 1963-1996 }\end{array}$ & IV and OLS regressions & $\begin{array}{l}\text { (O) Identify the role of national borders in explaning the synchronization of } \\
\text { European business cycles in comparison with the US regional cycles. } \\
\text { (R) There is a higher output and employment comovement within the U.S. than } \\
\text { within Europe. This difference is due to the national borders in European countries. } \\
\text { The border effects reflect lower level of trade and higher specialization. However, } \\
\text { the border effects have become smaller over time. }\end{array}$ \\
\hline Forni and Reichlin (2001) & $\begin{array}{l}82 \text { regions (in DEU, GBR, FRA, } \\
\text { ITA, BEL, NLD) and } 138 \text { regions (in } \\
\text { DEU, GBR, FRA, ITA, BEL, NLD, } \\
\text { GRC, ESP, POR) }\end{array}$ & $\begin{array}{l}\text { Nominal output or gross value } \\
\text { added / CPI } \\
1973-1993 \text { or } 1980-1993\end{array}$ & Dynamic factor model & $\begin{array}{l}\text { (O) Analyze the main features of the regional output fluctuations in Europe to } \\
\text { examine the potential role of European federal policies in stabilizing cycles. } \\
\text { (R) Europe is as integrated as the US states at the regional level. }\end{array}$ \\
\hline $\begin{array}{l}\text { Francis, Owyang, and } \\
\text { Savascin (2012) }\end{array}$ & $\begin{array}{l}\text { ARG, AUS, AUT, BGD, BEL, BOL, } \\
\text { BRA, CMR, CAN, CHL, COL, CRI, } \\
\text { CIV, DNK, DOM, ECU, SLV, FIN, } \\
\text { FRA, DEU, GRC, GTM, HND, } \\
\text { HKG, ISL, IND, IDN, IRL, ITA, } \\
\text { JAM, JPN, KEN, KOR, LUX, MYS, } \\
\text { MEX, MAR, NLD, NZL, NOR, } \\
\text { PAK, PAN, PRY, PER, PHL, PRT, } \\
\text { SEN, SGP, ZAF, ESP, LKA, SWE, } \\
\text { CHE, THA, TTO, GBR, USA, URY, } \\
\text { VEN, ZWE }\end{array}$ & $\begin{array}{l}\text { Real output } \\
1961-2007\end{array}$ & Dynamic factor model & $\begin{array}{l}\text { (O) Propose a new factor model with an endogenous block structure for the factor } \\
\text { loadings and examine the roles played by regional factors. } \\
\text { (R) Similarities in institutional factors such as legal systems and language diversity } \\
\text { are important for blocking. Regional factor has an important role. }\end{array}$ \\
\hline $\begin{array}{l}\text { Giannone and Reichlin } \\
\text { (2006) }\end{array}$ & $\begin{array}{l}\text { AUT, BEL, FIN, FRA, DEU, GRC, } \\
\text { IRL, ITA, LUX, NLD, PRT, ESP, } \\
\text { DEN, SWE, GBR }\end{array}$ & $\begin{array}{l}\text { Per-capita real output } \\
1970-2003\end{array}$ & $\begin{array}{l}\text { SVAR } \\
\text { concordance index }\end{array}$ & $\begin{array}{l}\text { (O) Analyze output dynamics in member countries of the Euro area and describe } \\
\text { stylized facts on output differentials within the union, the synchronization of } \\
\text { recessions, and the relation with respect to the U.S. cycles. } \\
\text { (R) Persistent idiosyncratic shocks lead to heterogeneity, but a common shock in the } \\
\text { Euro area is the most important factor in explaining output variation. A common } \\
\text { world shock is also important. Persistent shocks and low volatility are common } \\
\text { features of cycles in the Euro area. }\end{array}$ \\
\hline $\begin{array}{l}\text { Goncalves, Rodrigues, } \\
\text { Soares (2009) }\end{array}$ & $\begin{array}{l}\text { AUT, AUS, BEL, LUX, CAN, DEN, } \\
\text { FIN, FRA, GER, GRC, IST, IRE, } \\
\text { ITA, JPN, NLD, NZL, NOR. PRT, } \\
\text { ESP, SWE, CHE, GBR, USA }\end{array}$ & $\begin{array}{l}\text { Real output } \\
1980 \text { to } 2007\end{array}$ & DiD estimation & $\begin{array}{l}\text { (O) Examine whether business cycle comovements increased more among EMU } \\
\text { countries than among OECD countries after } 1999 \text {. } \\
\text { (R) Cycles among EMU countries are more correlated. }\end{array}$ \\
\hline $\begin{array}{l}\text { Guha and Banerji } \\
(1998 / 1999)\end{array}$ & EMU 28 countries & $\begin{array}{l}\text { Total employment } \\
\text { 1970-1997 }\end{array}$ & $\begin{array}{l}\text { Markov switching model } \\
\text { and bootstrapping }\end{array}$ & $\begin{array}{l}\text { (O) Examine the existence of regional cycles. } \\
\text { (R) German, French, and Italian employment cycles do not coincide with EMU's } \\
\text { total employment cycles. }\end{array}$ \\
\hline
\end{tabular}




\section{Europe}

\section{$\begin{array}{lllll}\text { Authors } & \text { Country Sample } & \text { Variables/ Period } & \text { Methodology } & \text { Objective ( O ) and Results ( R ) }\end{array}$}

Hegerty (2010)

(O) Examine the degree of business cycle comovements and the impact of world cycles in six CEEC countries.

(R) Mixed evidence about the strenght of business cycle comovements. Business cycles of some countries show high correlations with world cycles.

Koopman and Azevedo

(2008)

Larsson, Gaco, and

Sikstrom (2011)

Lee (2012)

AUT, BEL, FIN, FRA, GER, GRC, Real output IRE, ITA, LUX, NDL, POR, ESP, 1970-2010

the other 8 OECD countries.

Massmann and Mitchell AUS, BEL, FIN, FRA, GER, GRC, IP

(2004)

Montoya and De Hann Euro area (NUTS1's 53 regions) Gross value added (2008)
DEN, NOR, SWE, CHE, GBR and

IRE, ITA, LUX, PRT, and ESP

1960M1-2001M8

1970Q1 - 2001Q1

AUT, BEL-LUX, FIN, FRA, GER, Real output

DEN, FIN, NOR, SWE, Euro area Real output POR, and EU-4), and EU-4 (FRA,

DEU, ITA, and ESP)

1975-2005 AUT, BEL, GRC, IRE, LUX, NLD, 1970-2009
Multivariate Markov-

switching VAR

(O) Investigate the business cycle comovement among the Euro Area countries by estimating an unobserved components model that accounts for time-varying phase difference and time-varying relation between cycles.

(R) France and Germany show a high degree of comovement with the Euro Area cycles. Cycles in Spain, Italy and the Netherlands have become more correlated with cycles in the Euro Area.

SVAR

(O) Assess the long-run viability of the EMU.

(R) Euro zone shares many of the regional business cycle characteristics, and EMU is getting close to being an OCA.

Business cycle asymmetry (O) Examine whether business cycles in Nordic coutries have been converging to index method (Hassler, cycles in the Eurozone.

2003)

(R) Cycles in the Nordic countries did not converge to those in the EU-4 or the Euro area during 1970-2009. However, business cycles in Denmark and Finland, whose exchange rates are tied to the Euro, have become more synchronized with the Euro area cycles and the EU-4 during the Maastricht period (1993-2007).

Dynamic factor model $\quad$ (O) Analyze the evolution of comovements of cycles across the European countries with time-varying parameters over time.

R) Business cycle synchronization rose in European countries in the process to the third stage of EMU, but more convergence has not been observed since then.

Various measures

(O) Examine whether the differences in convergence measures matter in the case of euro area.

(R) The results are sensitive to the measures. There have been periods of convergence and divergence. The degree of synchronization has been increasing over

Correlation analysis, cluster analysis
(O) Examine the synchronization of regional business cycles in the Euro Area

(R) Synchronization on average has been increasing between Euro zone and Euro Area's regions with some exceptions. 
Europe

\begin{tabular}{|c|c|c|c|c|}
\hline Authors & Country Sample & Variables/ Period & Methodology & Objective ( O ) and Results ( R ) \\
\hline $\begin{array}{l}\text { Rodriguez-Pose and Fratesi } \\
\text { (2007) }\end{array}$ & GRC, ITA, PRT, ESP, FRA & $\begin{array}{l}\text { Real output per capita } \\
1980-2000 \\
1975-2005\end{array}$ & Regression & $\begin{array}{l}\text { (O) Sudy the extent of regional business cycle convergence in the southern periphery } \\
\text { of Europe. } \\
\text { (R) The degree of synchronization of cycles has been on average increasing between } \\
\text { the Euro zone and Euro area's regions. }\end{array}$ \\
\hline Seymen (2012) & $\begin{array}{l}\text { BEL, GER, ESP, FRA, ITA, NLD, } \\
\text { USA, EURO area (12 countries) + } \\
\text { SVK }\end{array}$ & $\begin{array}{l}\text { Real output per capita } \\
\text { 1970Q1-2009Q4 }\end{array}$ & Structural VAR & $\begin{array}{l}\text { (O) Examine the sources of business cycles in the Euro Area. } \\
\text { (R) The main driving force of Euro area business cycles is the global shock. This } \\
\text { shock becomes weaker in the EMU period than in the pre-EMU period. The sources } \\
\text { of business cycle heterogeneity are country-specific shocks, but the heterogeneous } \\
\text { responses to global shocks are not significant. }\end{array}$ \\
\hline Shin and Wang (2005) & $\begin{array}{l}\text { AUT, DNK, FIN, FRA, IRN, ITA, } \\
\text { GRC, GER, NDL, NOR, PRT, SPN, } \\
\text { SWE, GBR }\end{array}$ & $\begin{array}{l}\text { Real output } \\
1977-1999\end{array}$ & $\begin{array}{l}\text { Frankel and Rose type } \\
\text { regressions }\end{array}$ & $\begin{array}{l}\text { (O) Examine how the business cycles of European countries have been affected by } \\
\text { the increased trade among them. } \\
\text { (R) Intra-industry trade linkages are important in explaining business cycle in the } \\
\text { region. }\end{array}$ \\
\hline $\begin{array}{l}\text { Siedschlag and Tondl } \\
\text { (2011) }\end{array}$ & $\begin{array}{l}208 \text { Regions (NUT2) in the EU15 } \\
\text { (AUS, BEL, DEN, FIN, FRA, GER, } \\
\text { GRC, IRE, ITA, LUX, NLD, POR, } \\
\text { ESP, SWE, and GBR) }\end{array}$ & $\begin{array}{l}\text { Real output and value added } \\
1989-2002\end{array}$ & Panel regression & $\begin{array}{l}\text { (O) Examine the patterns and determinants of the comovement between regions in } \\
\text { the EU and the Euro Area. } \\
\text { (R) Trade leads to more synchronization. Industrial specialization and forex volatility } \\
\text { have direct and indirect effects on the divergence and convergence of cycles. }\end{array}$ \\
\hline Thorsrud (2012) & $\begin{array}{l}\text { USA, JPN, CAN, IND, KOR, MYS, } \\
\text { TWN, SGP, HKG, THA, AUS, NZL, } \\
\text { BRA, PER, CHL, ARG, MEX, BEL, } \\
\text { DEN, FRA, DEU, NLD, ESP, CHE, } \\
\text { SWE, GBR, NOR, ITA, FIN, POR }\end{array}$ & $\begin{array}{l}\text { Real output, IP, CPI, PPI } \\
\text { 1990Q1-2009Q4 }\end{array}$ & FAVAR & $\begin{array}{l}\text { (O) Analyze the importance of global and regional shocks' components in explaining } \\
\text { the movements in real and nominal variables. } \\
\text { (R) Global and regional components are important in North America, Asia, and } \\
\text { South America. In Europe, regional components have limited importance. Supply } \\
\text { shocks explain cycles in the long-run, demand shocks explain them in the short-run. }\end{array}$ \\
\hline $\begin{array}{l}\text { Weyerstrass, van Aarle, } \\
\text { Kappler, and Seymen } \\
\text { (2012) }\end{array}$ & $\begin{array}{l}\text { EU12 (AUT, BEL, DEU, ESP, FIN, } \\
\text { FRA, GRC, IRE, ITA, LUX, NLD, } \\
\text { PRT), SWE, SVK, SVN, ROU, } \\
\text { POLMLT, LTU, LVA, GBR, HUN, } \\
\text { EST, DEN, CZE, CYP, BGR, JPN, } \\
\text { USA }\end{array}$ & $\begin{array}{l}\text { Real output } \\
\text { 1970Q1-2007Q3 }\end{array}$ & $\begin{array}{l}\text { Correlation analysis; } \\
\text { Frequency domain } \\
\text { analysis; } \\
\text { Coherence; dynamic } \\
\text { correlation; and phase } \\
\text { analysis }\end{array}$ & $\begin{array}{l}\text { (O) Examine the changes in comovement between Euro area countries (particularly } \\
\text { after 1999) and between non-Euro area countries and the Euro area average. } \\
\text { (R) In the Euro area, no significant changes in the degree of comovement are } \\
\text { observed. }\end{array}$ \\
\hline
\end{tabular}


North America and Latin America and the Caribbean

\begin{tabular}{|c|c|c|c|c|}
\hline Authors & Country Sample & Variables/ Period & Methodology & Objective ( $O$ ) and Results ( R ) \\
\hline $\begin{array}{l}\text { Aiolfi, Catao, and } \\
\text { Timmermann (2011) }\end{array}$ & $\begin{array}{l}\text { LAC-4 (ARG, BRA, CHL, and } \\
\text { MEX) }\end{array}$ & $\begin{array}{l}\text { Index of Maddison }(2003) \\
\text { similar to real output } \\
1870-2004 \\
1950-2004 \text { (Factor model) }\end{array}$ & $\begin{array}{l}\text { Dynamic factor model; } \\
\text { Business cycle dating; } \\
\text { Regressions }\end{array}$ & $\begin{array}{l}\text { (O) Examine the sources of business cycle volatility using historical time series. } \\
\text { (R) There is cyclical commonality among LAC-4 (between individual country } \\
\text { components with the regional common factor as well as the global factor). The role } \\
\text { of the regional factor has been increasing over time, but the regional commonality is } \\
\text { mainly driven by external variables and common external shocks. }\end{array}$ \\
\hline $\begin{array}{l}\text { Allegret and Sand-Zantman } \\
\text { (2009) }\end{array}$ & ARG, BRA, CHL, MEX, URY & $\begin{array}{l}\text { Real output } \\
1991-2007\end{array}$ & Bayesian SVAR & $\begin{array}{l}\text { (O) Explore the possibility of forming a monetary union in the region, examine the } \\
\text { presence of common shocks, the impact of international disturbances and different } \\
\text { exchange rate regimes. } \\
\text { (R) Countries in the region are vulnerable to international disturbances transmitted } \\
\text { through the real and financial channels. Foreign variables conform the commonality } \\
\text { of business cycles in the region. }\end{array}$ \\
\hline Cerro and Pineda (2002) & $\begin{array}{l}\text { ARG, BOL, BRA, CHL, COL, ECU, } \\
\text { MEX, PRY, PER, URY, VEN }\end{array}$ & $\begin{array}{l}\text { Real output } \\
\text { 1960Q1-2000Q4 }\end{array}$ & $\begin{array}{l}\text { Correlation analysis, } \\
\text { Cofeature and } \\
\text { cointegration analysis }\end{array}$ & $\begin{array}{l}\text { (O) Study the degree of business cycle comovement in Latin American countries. } \\
\text { (R) Business cycle comovement in the region is very limited. Shocks are } \\
\text { idiosyncratic and the speed of adjustment differs across countries. }\end{array}$ \\
\hline $\begin{array}{l}\text { Chiquiar and Ramos- } \\
\text { Francia (2005) }\end{array}$ & MEX, USA & $\begin{array}{l}\text { Manufacturing production } \\
\text { 1980M1-2004M6 }\end{array}$ & $\begin{array}{l}\text { Cointegration and error } \\
\text { correction model }\end{array}$ & $\begin{array}{l}\text { (O) Test whether the NAFTA has enhanced the business cycle comovement between } \\
\text { MEX and USA. } \\
\text { (R) More business cycle synchronization among the NAFTA members can be } \\
\text { attributed to the stronger production-side links between Mexico and the U.S. } \\
\text { manufacturing sectors after the NAFTA was enacted. China's entry has a significant } \\
\text { third country effect on business cycle comovements among the NAFTA countries. }\end{array}$ \\
\hline $\begin{array}{l}\text { Cuevas, Messmacher, and } \\
\text { Werner (2002) }\end{array}$ & $\begin{array}{l}\text { ARG, BRA, CAN, ChL, MEX, } \\
\text { USA, FRA, GER, IRE, ITA, POR, } \\
\text { ESP, GBR }\end{array}$ & $\begin{array}{l}\text { Real output, IP } \\
\text { 1981-2001 }\end{array}$ & $\begin{array}{l}\text { Factor Analysis } \\
\text { Simple regression } \\
\text { analysis } \\
\text { Correlation }\end{array}$ & $\begin{array}{l}\text { (O) Examine the changes in the degree of synchronization between Mexico and its } \\
\text { NAFTA partners. } \\
\text { (R) The synchronization over time has increased. }\end{array}$ \\
\hline Fiess (2007) & $\begin{array}{l}\text { CRI, SLV, GTM, HND, NIC, PAN, } \\
\text { ARG, BRA, MAX, CAN, USA, } \\
\text { FRA, GER, PRT, SPN, GBR }\end{array}$ & $\begin{array}{l}\text { Real output } \\
1965-2005 \\
\text { IP } \\
1965 \mathrm{M} 1-2005 \mathrm{M} 1\end{array}$ & Frankel and Rose type & $\begin{array}{l}\text { (O) Construct a model that captures the current trade structure and the degree of } \\
\text { business cycle synchronization between Central America and the United States. } \\
\text { (R) Within Central America, the degree of comovement is not very strong, but the } \\
\text { degree of comovement between the U.S.A. and the region is high in some cases. } \\
\text { Trade and remittance flows between the U.S.A. and Central America can partly } \\
\text { explain the synchronization. }\end{array}$ \\
\hline Herrera (2004) & MEX, USA & $\begin{array}{l}\text { Real output } \\
\text { 1993Q1-2001Q4 }\end{array}$ & VECM & $\begin{array}{l}\text { (O) Examine whether Mexico and the U.S.A. share common business cycle } \\
\text { movements in the short- and the long-run. } \\
\text { (R) Mexico and the U.S. appear to share a common cyclical component since } 1993 .\end{array}$ \\
\hline
\end{tabular}


North America and Latin America and the Caribbean

\section{Authors}

Country Sample

\section{Variables/ Period}

Jocobo (2002)

ARG, BOL, BRA, CHL, PRY, URY Real output

1970-1997

SVAR

Real outp output, IP 1980-2002 (2005)

Loayza, Lopez, and Ubid (2001)

Male (2011)

Mumtaz, Simonelli, and Surico (2011)

Phillips and Canas (2008) Four Texas border Metropolitan

Phillips and Canas (2008) Four Texas border Metropolitan

ARG, BRA, CHL, COL, CRI, DMA, Sectral real outpu ECU, SLV, HND, MEX, PRY, 1970-1994 SGP, THA, TWN, AUS, BEL, FRA, GER, ITA, ESP

CIV, MWI, NGA, SEN, ZAF, ISR, JOR, MAR, TUN

Real output ARG, BRB, BRA, CHL, COL MEX, PER, TTO, URY, BGD, HKG, IND, KOR, MYS, PAK, PHL, TUR,

HUN, LTU, MKD, ROU, SVK, SVN, GBR, USA, JPN

ATG, AUS, AUT, BEL, BRA, CAN, Real output, CPI CHL, CHN, COL, DNK, FIN, FRA， 1860-2007 DEU, GRC, HUN, IND, IRL, ITA,

JPN, MEX, NLD, NZL, NOR, PER,

PHL, POL, PRT, ESP, SWE, CHE,

Employment, retail sales, wages, Dynamic factor model Statistical Areas(MSAs), USA, MEX unemployment rate 1981-2002

Sosa (2008)

MEX, USA

Real output 1996Q1-2007Q4

Swiston and Bayoumi (2008)

MAX, CAN, USA, JPN, Euro area Real output 1970Q1-2007Q2

Torres and Vela (2003)

Regressions similar Stockman (1988) and Costello (1993)
Real output 1991Q1-2001Q4
Methodology

\section{Objective ( O ) and Results ( R )}

(O) Analyze the homogeneity of cycles in Latin Americancouris.

(R) The similarity cannot be found and the benefit of policy coordination is limited, even though the timing of peaks and troughs coincide in some countries.

(O) Analyz the impact of NAFTA on business cycles in Mexico using various methods.

(R) Regional factors have become more important in driving business cycles with the advent of NAFTA.

(O) Identify country-specific, sector-specific, and common shocks for Latin American, European, and East Asian countries.

(R) The degree of commonalities in cycles is low in Latin America compared with Europe and Asia. Latin American countries have their dominant domestic idiosyncratic factors.

Dating method (Harding $\quad$ (O) Examine the business cycle characteristics and synchronicity for the large sample and Pagan, 2002) of developing countries.

(R) Business cycle turning points are more synchronized among the Latin America and Asian countries than the other developing countries. No clear patterns of concordance are found within region and across regions, but some developing countries show a higher degree of concordance with the US or Japan.

Dynamic factor model $\quad$ (O) By using historical data, examine jointly the comovement of real and nomina variables.

(R) In explaining each country's output growth, the role of comovements with the world cycles has become less important while the role of comovements with the regional cycles has become more important.

(O) Examine how MSAs' business cycles synchronize with those of the broader economies that surround MSAs.

(R) MSAs are involved more in US and Mexico's cycles and in particular after 1994 that tendency has been accelerated.

SVAR model with block (O) Assess the impact of the recent slowdown of the US economy on Mexico. exogeneity restrictions (R) The shocks to U.S. demand for Mexico's exports account for 40 percent of Mexico's output fluct

Quasi-Bayesian approach (O)Examine business cycle comovement and the spill-over across NAFTA. to identification within a Examine the size and sources of spillovers from the major regions of the rest of the VAR framework world to Canada and Mexico.

(R) Canadian cycles are linked to the US cycles throughout the last few decades. Mexican cycles are dominated by domestic factors from 1970 through 1995; and Mexican cycles are dominated by domestic factors from 1970 through 1995; and
U.S. shocks play a more substantial role in affecting the Mexican cycles in recent U.S. shocks
decades.

Correlation analysis and $\quad$ (O) Examine whether the degree of business cycle synchronization has increased in simple regression response to the increase in manufacturing trade between the US and Mexico during the last ten vears.

ement between Mexico and the US has been going up as the trade linkages have become stronger after the NAFTA. 
Middle East and North Africa, and Sub-Saharan Africa

\begin{tabular}{|c|c|c|c|c|}
\hline Authors & Country Sample & Variables/ Period & Methodology & Objective ( O ) and Results ( R ) \\
\hline $\begin{array}{l}\text { Balcilara and Danjub } \\
\text { (2010) }\end{array}$ & $\begin{array}{l}\text { BHR, IRN, ISR, JOR, KWT, LBY, } \\
\text { OMN, SAU, SYR, ARE, DZA, } \\
\text { EGY, MLT, MAR, TUN }\end{array}$ & $\begin{array}{l}\text { Real output } \\
1960-2007\end{array}$ & $\begin{array}{l}\text { Small open economy } \\
\text { SVAR }\end{array}$ & $\begin{array}{l}\text { (O) Examine the relative importance of country-specific, regional, and global shocks } \\
\text { in explaining output volatility in } 15 \text { MENA countries. } \\
\text { (R) The country specific factors are the most important whereas the regional factors } \\
\text { play a minor role. }\end{array}$ \\
\hline $\begin{array}{l}\text { Canova and Ciccarelli } \\
\text { (2012) }\end{array}$ & $\begin{array}{l}\text { POR, ESP, FRA, ITA, GRE, ALB, } \\
\text { MCD, CYP, TUR, ISR, SYR, EGP, } \\
\text { TUN, ALG, MOR }\end{array}$ & $\begin{array}{l}\text { Real GDP, consumption, } \\
\text { investment } \\
1980-2009\end{array}$ & FAVAR & $\begin{array}{l}\text { (O) Examine the comovement of business cycles of the Mediterranean basin } \\
\text { countries. } \\
\text { (R) Convergence and divergence coexist in the region. They are temporary in nature } \\
\text { and reversible. Domestic cyclical fluctuations are still largely due to national causes. }\end{array}$ \\
\hline Hakura (2007) & $\begin{array}{l}67 \text { developing countries (MENA: } \\
\text { DZA, EGY, IRN, ISR, JOR, MAR, } \\
\text { SYR, TUN, and TUR) }\end{array}$ & $\begin{array}{l}\text { Real output } \\
1970-2003\end{array}$ & $\begin{array}{l}\text { Bayesian dynamic factor } \\
\text { model }\end{array}$ & $\begin{array}{l}\text { (O) Explore the factors driving the volatility of cycles. } \\
\text { (R) Country-specific factor is the most important one in explaining the volatility of } \\
\text { the MENA cycles. }\end{array}$ \\
\hline Mehrara and Oskoui (2007) & $\begin{array}{l}\text { Oil-exporting } 4 \text { countries (IRN, } \\
\text { SAU, KWT, IDN) }\end{array}$ & $\begin{array}{l}\text { Real output (real industrial value } \\
\text { added) } \\
1970-2002\end{array}$ & $\begin{array}{l}\text { SVAR a la Blanchard and } \\
\text { Quah (1989) and Clarida } \\
\text { and Gali (1994) }\end{array}$ & $\begin{array}{l}\text { (O) Identify which shocks (nominal demand, real demand, supply, or oil price } \\
\text { shocks) are important in oil-exporting countries. } \\
\text { (R) Iran and Saudi Arabia are strongly affected by oil price shocks, while Kuwait is } \\
\text { influenced by domestic supply shocks. }\end{array}$ \\
\hline Neaime (2005) & $\begin{array}{l}\text { EGY, JOR, MAR, and TUR, SAU, } \\
\text { KWT, BHR, UAE }\end{array}$ & $\begin{array}{l}\text { Real output and its components } \\
1980-2002\end{array}$ & Panel regression & $\begin{array}{l}\text { (O) Examine the sources of macroeconomic volatility in the MENA region. } \\
\text { (R) Financial openness (gross capital flows as a ratio to GDP) tends to increase } \\
\text { consumption volatility. }\end{array}$ \\
\hline $\begin{array}{l}\text { Sussmuth and Woitek } \\
\text { (2004) }\end{array}$ & $\begin{array}{l}\text { FRA, ITA, GRE, ESP, ISR, SYR, } \\
\text { TUR, ALG, EGY, MOR, WBG }\end{array}$ & $\begin{array}{l}\text { GDP } \\
1950-1998\end{array}$ & AR models & $\begin{array}{l}\text { (O) Analyze the main features of business cycles. } \\
\text { (R) There are differences between the business cycles of the European and the } \\
\text { MENA countries. There are changes in degree of business cycle comovement over } \\
\text { the observation period of these two groups. }\end{array}$ \\
\hline Tapsoba (2010) & 53 African countries & $\begin{array}{l}\text { Real output } \\
1965-2004\end{array}$ & $\begin{array}{l}\text { Frankel and Rose type } \\
\text { SVAR }\end{array}$ & $\begin{array}{l}\text { (O) Examine the role of trade linkages in explaining business cycle synchronization } \\
\text { in Africa. } \\
\text { (R) Trade intensity among African countries has enhanced business cycle } \\
\text { comovements. }\end{array}$ \\
\hline
\end{tabular}

